University of Louisville

ThinkIR: The University of Louisville's Institutional Repository

Electronic Theses and Dissertations

8-2019

\title{
Pedagogies of possibility : a study reconceptualizing the teacher's role in a reggio-inspired urban preschool classroom.
}

Christina Louise Angleton

University of Louisville

Follow this and additional works at: https://ir.library.louisville.edu/etd

Part of the Curriculum and Instruction Commons, Early Childhood Education Commons, and the Elementary Education Commons

\section{Recommended Citation}

Angleton, Christina Louise, "Pedagogies of possibility : a study reconceptualizing the teacher's role in a reggio-inspired urban preschool classroom." (2019). Electronic Theses and Dissertations. Paper 3282.

https://doi.org/10.18297/etd/3282

This Doctoral Dissertation is brought to you for free and open access by ThinkIR: The University of Louisville's Institutional Repository. It has been accepted for inclusion in Electronic Theses and Dissertations by an authorized administrator of ThinkIR: The University of Louisville's Institutional Repository. This title appears here courtesy of the author, who has retained all other copyrights. For more information, please contact thinkir@louisville.edu. 
PEDAGOGIES OF POSSIBILITIY:

\title{
A STUDY RECONCEPTUALIZING THE TEACHER'S ROLE IN A REGGIO- INSPIRED URBAN PRESCHOOL CLASSROOM
}

By

Christina Louise Angleton

B.S., Southern Illinois University, 2006

\begin{abstract}
A Dissertation
Submitted to the Faculty of the

College of Education and Human Development of the University of Louisville in Partial Fulfillment of the Requirements

for the Degree of
\end{abstract}

Doctor of Philosophy

in Curriculum and Instruction

Department of Early Childhood and Elementary Education

University of Louisville

Louisville, KY

August 2019 
Copyright 2019 by Christina Louise Angleton

All rights reserved 

PEDAGOGIES OF POSSIBILITY:

A STUDY RECONCEPTUALIZING THE TEACHER'S ROLE IN A REGGIO-INSPIRED URBAN PRESCHOOL CLASSROOM

\author{
By \\ Christina Louise Angleton \\ B.S., Southern Illinois University, 2006 \\ A Dissertation Approved on
}

June 26, 2019

by the following Dissertation Committee:

Dissertation Director

Dr. Kathryn F. Whitmore

Dr. James Chisholm

Dr. Michèle Foster

Dr. Mary P. Sheridan

Dr. Renita Schmidt 


\section{DEDICATION}

\section{To Mark and Lola}

for rooting me on from the beginning and reminding me regularly that I could do this 


\section{ACKNOWLEDGMENTS}

I would like to thank my advisor and mentor, Dr. Kathy Whitmore, for her constant support and for recognizing my potential and nurturing me from the beginning. I have learned so much from you and I'm forever grateful. I also extend thanks to Dr. James Chisholm, who never failed to lift me up; Dr. Michèle Foster, from whom I learned so much, even in casual conversation; Dr. Nita Schmidt for expanding my children's lit horizons in the best possible ways; and Dr. Mary P. Sheridan for challenging me to think beyond my comfort zone.

Special thanks to Shauntá Miller-Crumes, teacher extraordinaire, for welcoming me into her classroom, making me feel a part of her community, and for co-researching with me. Thanks also to Sharon Hemingway and the entire Keystone Learning Academy family - I've appreciated your gracious welcome from my very first visit, and this study

would not have been possible without your support. Deep appreciation to Jenn Pruitt and Lisa Branstetter of the Excellence Academy - it has been such a privilege to learn from and alongside you both.

I could not have achieved this goal without the support of the following individuals: my parents, Bill and Rhonda Dougherty; Leah Halliday and Shannon Putman, dear friends, suppliers of gifs, and two of the strongest women I know; janelle henderson and Renea Griffin, amazing friends who challenged me, rooted me on, and kept me in check; and the entire Insta village, especially Deepthi and the \#llamasquad, 
Alia, Summer, and Lisa - literally could not have gotten through this without your constant solidarity, supportive texts, and commiseration.

Finally, I must acknowledge the dissertation survival kit: Zephyr the long dog, the people at Chipotle who knew me by name, the Judge John Hodgman podcast, "Monody" by TheFatRat \& Laura Brehm on a constant loop, Maggie Stiefvater's Raven Cycle audiobooks, and an obscene amount of coffee. 


\title{
ABSTRACT \\ PEDAGOGIES OF POSSIBILITY: \\ A STUDY RECONCEPTUALIZING THE TEACHER'S ROLE IN A REGGIO-INSPIRED URBAN PRESCHOOL CLASSROOM
}

\author{
Christina Louise Angleton
}

June 26, 2019

The Reggio Emilia approach to early childhood education is an innovative and often imitated "way of being" with young children (Rinaldi, 2006). Reggio-inspired teachers enact rich pedagogical stances in their work with young children. In North American contexts, the approach is frequently associated with wealthy, suburban communities. Adopting a feminist methodology, this dissertation explores the pedagogical moves one teacher made as she enacted the identity of a Reggio teacher in an urban preschool classroom. The theoretical framework guiding this study is grounded in feminist poststructural, postmodern, and decolonization scholarship, each of which inform a movement known as Reconceptualizing Early Childhood Education (RECE). RECE works to disrupt assumptions about children, childhood, and early educators, providing counternarratives to deficit perspectives often associated with children of color, their families, neighborhoods, and teachers. This dissertation argues for reconceptualizing the teacher's role as she enacts pedagogies that create spaces for children to demonstrate their myriad competencies and suggests that feminist methodologies result in more equitable researcher-participant relationships. 


\section{TABLE OF CONTENTS}

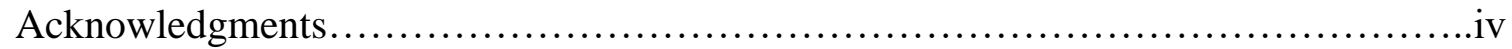

Abstract............................................................................

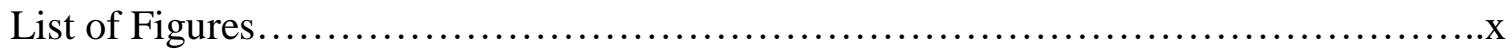

Chapter One: Theoretical Framework ........................................

Reggio Emilia: A Philosophical Approach................................6

A Community of Learners: The Excellence Academy........................10

Theoretical Framework............................................... 13

Research Questions...............................................21

Chapter Two: Review of Literature.......................................... 24

Introduction........................................................ 24

Reggio in Urban Spaces..............................................24

Reconceptualizing Early Childhood Education............................26

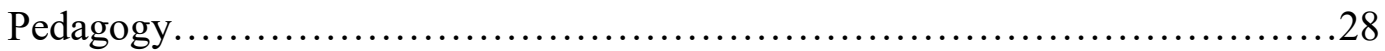

Time in Early Childhood Classrooms..................................29

Curriculum in Early Childhood Classrooms................................ 31

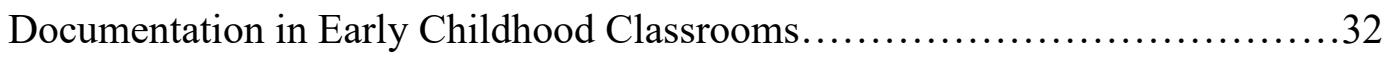

Learning Stories in Reggio-Inspired Early Childhood Classrooms...............36

Conclusion........................................................ 37

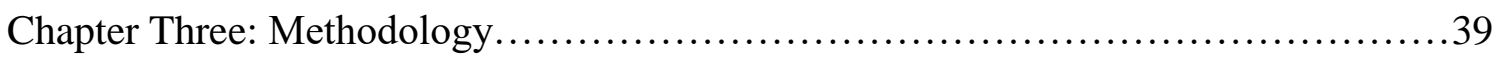

Research Questions.................................................. 39

Feminist Methodologies............................................40 
Positionality

Study Design................................................................. 44

Feminist Ethnographic Methods..........................................45

Learning Stories as Elicitation Method.....................................49

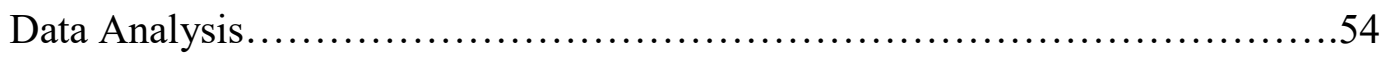

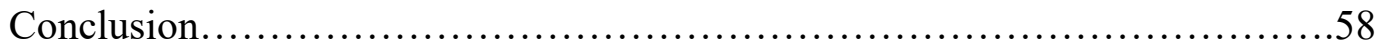

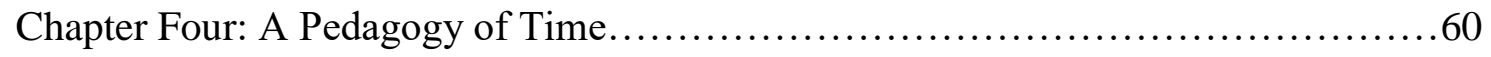

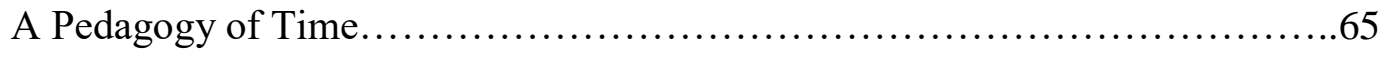

Possibilities in a Pedagogy of Time....................................... 77

Chapter Five: A Pedagogy of Inviting ......................................... 79

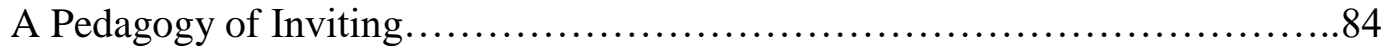

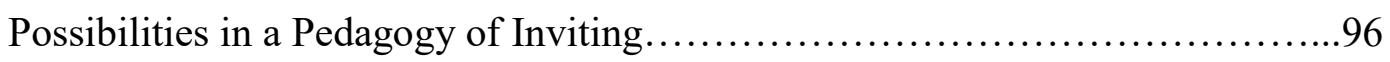

Chapter Six: A Pedagogy of Documenting..........................................99

A Pedagogy of Documenting............................................... 101

Possibilities in a Pedagogy of Documenting..................................114

Chapter Seven: Pedagogies of Possibility ........................................117

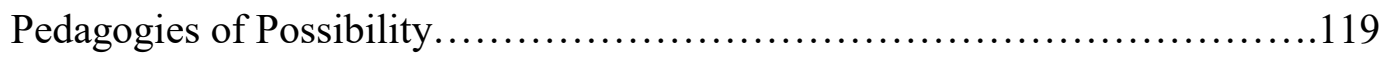

Disrupting Deficits: A Counternarrative......................................122

Reconceptualizing Children - And Teachers.............................124

An Unexpected Outcome.................................................

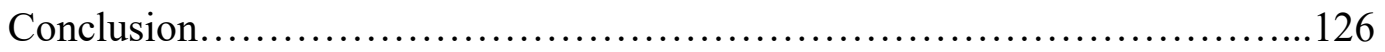

Implications for Future Research and Practice.............................128

Final Thoughts........................................................ 130 
References................................................................ 131

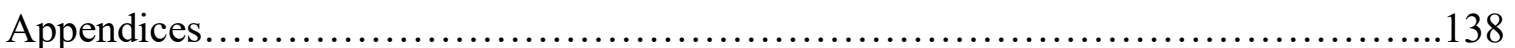

Curriculum Vitae....................................................... 140 


\section{LIST OF FIGURES}

Figure

Page

1.1 Photos of teachers.........................................................

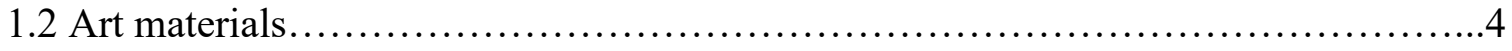

1.3 Personal touches...........................................................

3.1 Timeline for data collection...........................................45

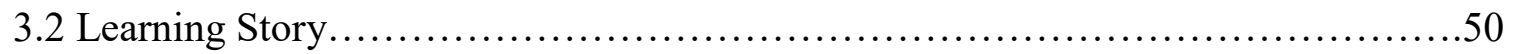

3.3 Abbreviated code book................................................. 57

4.1 Airport dramatic play..................................................61

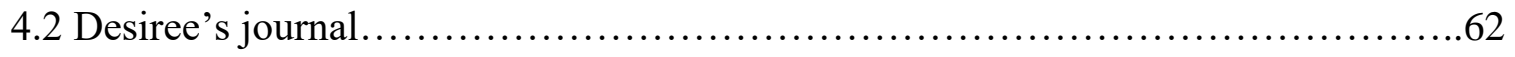

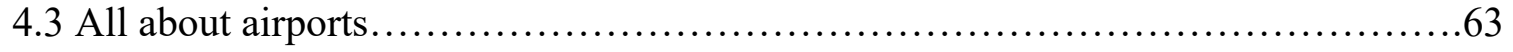

4.4 Airport props........................................................64

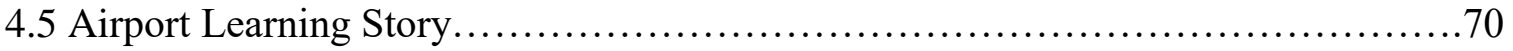

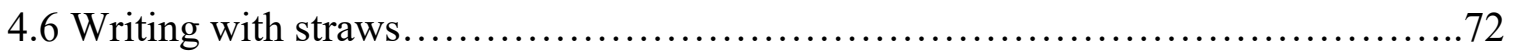

4.7 Save signs.......................................................... 75

5.1 Light on Shauntá's watch................................................ 80

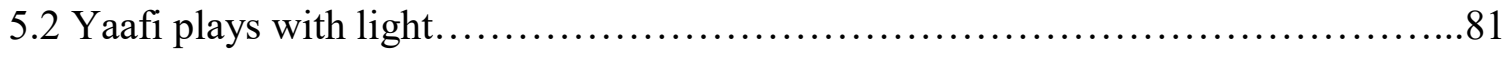

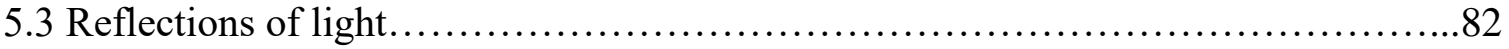

5.4 Light and shadow documentation....................................... 87

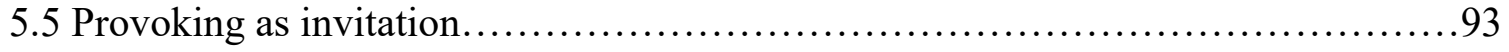




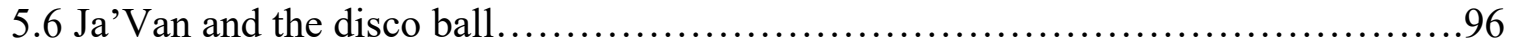

6.1 Aafiya's robot story.........................................................

6.2 Capturing the moment............................................... 104

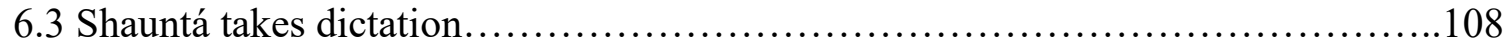

6.4 Aafiya's robot sketch............................................... 114 


\section{CHAPTER ONE: THEORETICAL FRAMEWORK}

The site for this study was Shauntá Miller-Crumes' preschool classroom at Keystone Learning Academy ${ }^{1}$, an early childhood center that is tucked in the center of one of the lowest income housing projects in a southern United States (U.S.) city. Keystone is a rich, nurturing space for 70 infants through preschool-aged children from African American and Somali refugee families. The childcare center is attached to a community center and sits across the street from the buildings that comprise the community housing. Visitors to the center often question Keystone teachers about the safety of the neighborhood and state they would "feel unsafe" taking children outside to play. These images, born out of deficit perspectives and negative stereotypes of children of color, their families, and their neighborhoods, often result in disbelief about the center's use of the Reggio Emilia approach - an innovative approach to early childhood education - and sometimes lead to cancellations of visits to the school. "They find out where it is," one teacher told me, "and they decide not to come. They don't want to risk it." Those who do "risk it," however, often leave with broadened ideas about the school and about the competencies and capabilities of the children and teachers in it.

\footnotetext{
${ }^{1}$ I use adults' real names, as well as the name of the center, with permission; children's names are pseudonyms.
} 
Entering the front door at Keystone, visitors are greeted by the hush of calm, although enthusiastic welcomes are shared frequently by one of the many volunteer "grannies" regularly stationed at the front desk throughout the day. Soft sounds of bubbling water emanate from a large aquarium. Immediately to the right of the front door, and directly across from the smiling "granny," are more shining faces, this time smiling back from the framed photos of teachers and staff that are artfully arranged on the wall above a shelf full of natural materials and potted plants (see Figure 1.1). Visitors can't help but smile back at the teachers in those frames - joy radiates from each glossy photo.

Walking toward the center of the building, visitors see a squishy loveseat, just waiting to be occupied by a child entering for the day or by a teacher taking a quick break. Eyes are drawn to documentation panels that tell the stories - through words and photos - of children's inquiries and joyful learning. Child-generated art, in the form of paintings, sculptures, and hangings, fill the space with the air of an art gallery. A miniature blue mailbox for family communications is mounted to the wall over a table with a large basket of apples. A sign above the basket reads "Parent Snacks. Please help yourself!" 


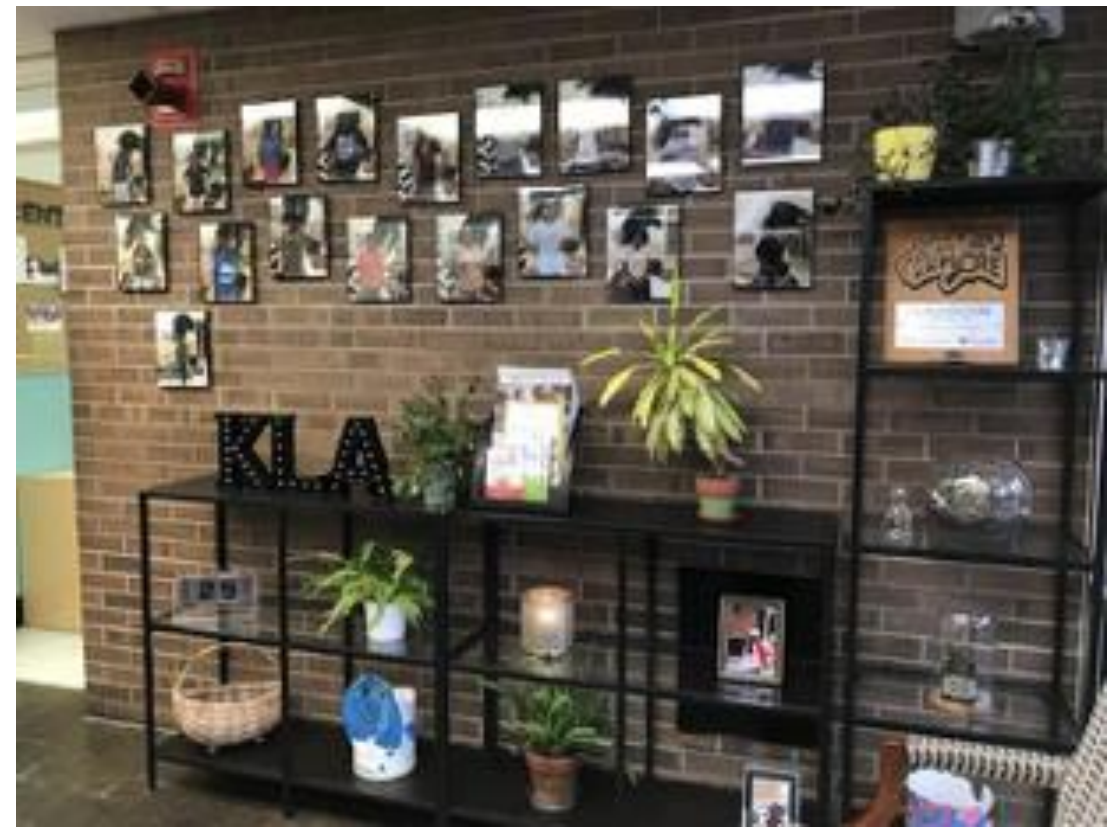

Figure 1.1. Photos of teachers in the foyer at Keystone Learning Academy.

Moving beyond the foyer, the hallway splits in two directions. To the left are the infant rooms, toddler rooms, an indoor playspace, and the kitchen. To the right is the center's atelier, a shared art studio lit from above with skylights that houses the finished and in-progress works of art by the Keystone children. A light table, covered in a thin layer of sand with a canister of paintbrushes to one side, shows the outline of a wobbly heart, an artifact of a child's presence there earlier in the day. Storage shelves in the atelier are works of art in themselves, brimming with glass jars full of color-coordinated writing tools, blocks of clay, baskets of fabric, and transparent containers of collage materials and other trinkets (see Figure 1.2). Shelves and documentation panels keep record of the atelier's use: finished and in-progress pieces of art alongside photos of child artists-in-action dipping paintbrushes into jars of paint or smashing lumps of clay together to create figures. A loom rests on a tabletop, with lengths of ribbon and yarn coming together to form something new. 

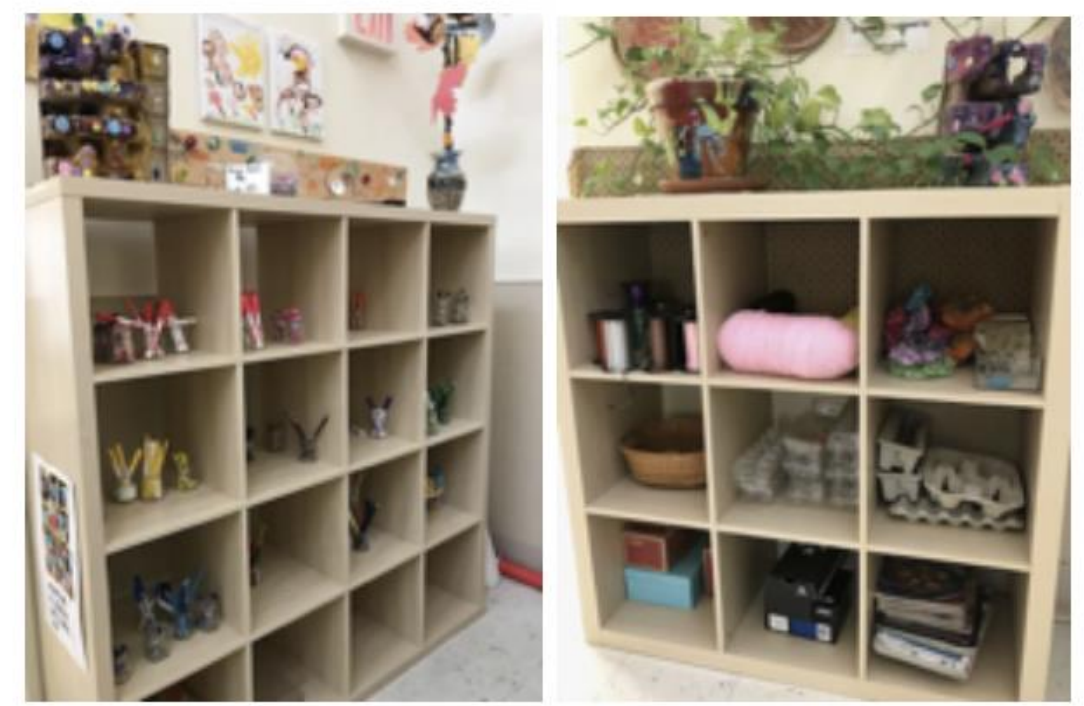

Figure 1.2. Materials are displayed artfully in the atelier.

Walking through the atelier, visitors get their first glimpse of Shauntá's

classroom. In a wide hallway just outside the classroom door, towers of blocks, baskets full of materials called loose parts, and shelves of building materials line the walls, while in-progress structures of blocks and other materials bear signs reading, "Stop! Don't TOUCH! I want to save it!" This stretch of hall is the perfect spot for children to move their bodies as they create, both collaboratively and independently, and is a testament to the ways teachers at Keystone think about their building in very functional ways. No space is ever wasted.

Stepping carefully past block sculptures, visitors cross the threshold into Shauntá's classroom. A productive hum fills the space, which is darker than the skylit brightness of the atelier. Lights on dimmers overhead cast a soft buttery light. Lamps and other various light sources at floor and table levels, including a small overhead projector against one wall, provide pops of brightness in each area of the room. The hardwood floors stretch from end to end of the space, sprinkled in several places with woven rugs in 
earth tones. To the left of the door, a narrow shelf invites experimentation with different sounds: bells for jangling, drums for banging, and scarves for swirling. A simple, handwritten card on top of the shelf asks, "Can you make a sound?" To the right, tall wooden cubbies stretch the length of the wall, and various jackets and backpacks poke out from the wooden confines of each child's personal space. Linen baskets occupy the space at the bottom of each cubby, with smiling photos of the children and child-generated name tags adorning each one.

The rest of the room, divided into sections by low wooden shelves or other furniture, reminds visitors more of an open-plan studio apartment than a classroom. The small but significant personal touches - vases of flowers, and framed photos of children writing in journals or performing a puppet show - prompt visitors to remark on the "homeyness" of the space, a stark contrast from the brightly lit, primary-colored, and plastic-crowded classrooms often associated with preschool (see Figure 1.3).

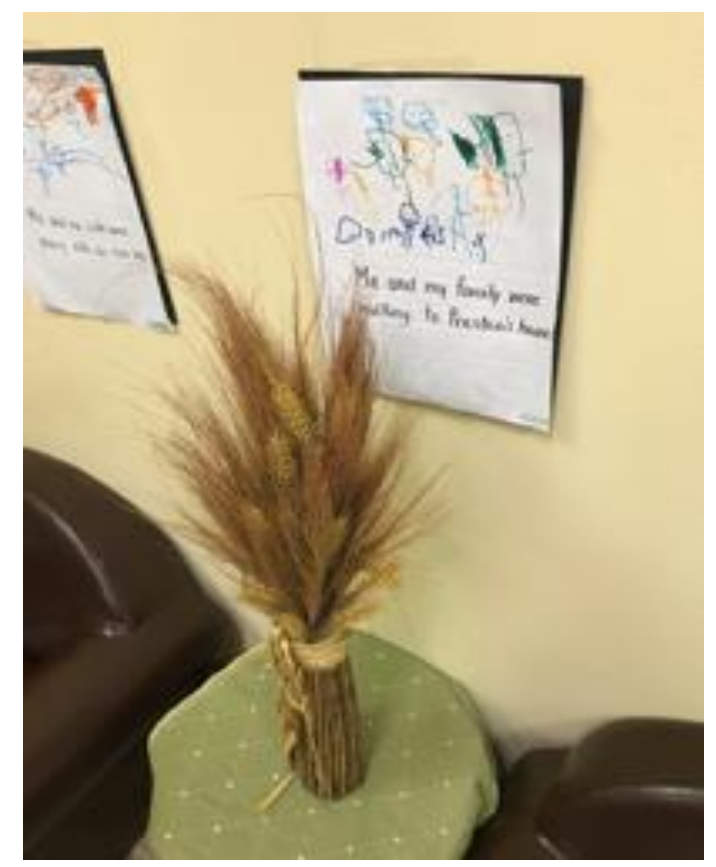

Figure 1.3. Personal touches create a homey feeling in Shauntá's room. 
Visitors soon see that Keystone is not typical of other early childhood centers. Absent are the sounds of prolonged crying, the smell of industrial cleaners, children sitting and waiting for teachers to distribute cookie-cutter craft projects. No early learning center is perfect, and Keystone doesn't profess to be, but this site gives life to an important story about what is possible in early childhood spaces. In Shauntá's classroom - as well as in the atelier, the outdoor nature space, and the light exploration room - the scene is set for two teachers and twelve children to engage daily in play, exploration, and meaning making, with and in response to one another. This space was the site for my study, where I sought to understand the complex and dynamic role Shauntá played in her teaching practice, situated within the Reggio-inspired urban preschool where she teaches. Using ethnographic methods, I documented the pedagogical moves Shauntá made in her everyday teaching practices. In the remainder of this chapter, I explain the Reggio Emilia approach to early childhood education, the context for my study and research questions, and the reconceptualist theoretical framework that shapes my researcher stance, data collection, and data analysis methods.

\section{Reggio Emilia: A Philosophical Approach}

The Reggio philosophy is an approach to early childhood education developed in the municipality of Reggio Emilia in Northern Italy under the guidance of educator Loris Malaguzzi in the aftermath of World War II (Gandini, 2012a; Rinaldi, 2006). The Reggio approach, as it is commonly known in North America, is strongly invested in the formation and maintenance of relationships, and views children as strong, capable, and competent, a concept referred to as the "image of the child." The educators in Reggio conceptualize the philosophy as a "way of being" with children (Rinaldi, 2006), and, 
along with the famously beautiful schools and progressive approaches to the education of even the youngest children (Malaguzzi, 2016), it is an inspiring and often imitated approach to early childhood education around the world. At its most basic, the philosophy views children as competent and capable protagonists of their own learning, values partnership between children and adults as co-constructors of knowledge, and uses various forms of documentation to make the learning and thinking of children visible to all (Gandini, 2012). Additionally, the philosophy is enacted through a frame developed by Malaguzzi and known as "The Hundred Languages," which asserts that children enact multiple ways of knowing and that each of these myriad ways carries value. "Children experiment and develop competencies in using spoken language, gestures, drawing, painting, building, clay and wire sculpture, shadow play, collage, dramatic play, music, and emerging writing, to name but a few" (Edwards, Gandini, \& Forman, 2012, p. 7).

Reggio, as it is often called, is both a philosophy of and an approach to early childhood education, drawn from multiple theories and traditions of early childhood education. It is not independently a theory, but rather operates as a system of beliefs shared by educators - an ideological framework that informs their work with young children. Malaguzzi describes the "versatility of theory and research" of the Reggio approach (Gandini, 2012, p. 39), and how Reggio educators' thinking was and continues to be influenced by multiple and diverse theorists and schools of thought. He cites Dewey, Piaget, Vygotsky, and Montessori, among other progressive and sociocultural educationists, as influential on his thinking as he and his colleagues conceptualized a new way of educating young children. The approach operates within a social constructivist perspective, one that understands child learning as a product of interaction with other 
children, adults, and the environment. These perspectives "contribute to structure an education based on relationship and participation" (p. 43).

Thus, the Reggio philosophy can be described as built on several foundational tenets that influence and are influenced by the relational nature described by Malaguzzi. Reggio teachers foster relationships by identifying and enacting innumerable pedagogies. The enactment of multiple and diverse pedagogies shaped my research questions and were the focus of this study.

Pedagogical work in Reggio Emilia can be described as relational, built upon dialogue and exchange (Rinaldi, 2006). Reggio educators view pedagogy as "a general framework within which [they] think about education, growing out of both its particular cultural context and of cross-fertilization with outside forces, paradigms, and practices" (p. 10). The cultural context and practices of the municipal preschools of Reggio Emilia inform the foundational tenets that comprise its philosophy:

- the image of the child as competent and capable (Edwards, Gandini, \& Forman, 2012);

- curriculum that is "child-originated and teacher-framed" (Forman \& Fyfe, 2012, p. 248), often referred to as emergent curriculum;

- a view of the physical classroom environment as the "third teacher," after families and teachers (Gandini, 2012b); and

- pedagogical documentation, the process of making children's learning visible through narrated displays containing photos of children and their work (Rinaldi, 2006). 
In the preschools of Reggio Emilia, a pedagogista, or pedagogical coordinator, oversees several schools and offers support to the teachers and children in each (Cagliari, Filippini, Giacopini, Bonilauri, \& Margini, 2012). Similar to the preschool coaches in this study, the pedagogista supports teachers as they navigate the practices of the Reggio philosophy, such as observing children and collecting documentation. Collectively, they work to support and coordinate the resources teachers and children need to pursue their ongoing projects.

Reggio educators believe that all learning happens in response to a theory (Malaguzzi, 2016). Theories, once expressed, communicated, and listened to, become the basis for curriculum development in the schools and the pedagogical work enacted by teachers in their work with children. Reggio educator and scholar Rinaldi (2006) articulates, "Herein lies the basis for the "pedagogy of relationships and listening"” (p. 234). Pedagogical work in Reggio Emilia is based in relationships - between teachers and children, school and home, human and environment, and the countless other relationships in which children and adults engage daily. Pedagogical work as a whole, therefore, is put into practice in response to how teachers think about and enact various ways of being with children, such as the "pedagogy of well-being," the "pedagogy of relations," the "pedagogy of continuity," and the "pedagogy of listening," among many others (Edwards, Gandini, \& Forman, 2012, p. 11).

It is important to mention that these pedagogies, as well as the other tenets of the Reggio philosophy, are never separated; rather, each informs the others in harmony to guide and inform the ways in which Reggio educators develop relationships with children, families, and the communities in and around the schools. Because of their 
progressive practices and aesthetically pleasing schools, Reggio educators are often imitated in North America - or rather, imitations are often attempted. Frequently, however, the fundamental elements of the philosophy are lost in translation, for reasons complicated and complex, not least of which are the restraints placed on preschools and child care centers on the Western side of the globe. Pacini-Ketchabaw, Nxumalo, Kocher, Elliot, and Sanchez (2015) note that the spirit of the approach is lost in North American contexts, primarily because our systems of child care and early education are based on narrow views of children and childhood. They maintain that

the work accomplished in early childhood by people in Reggio Emilia has been (mis)interpreted by many in the North American context as an evolutionary project - one that builds on existing positivist ideas. The Reggio programs and the ideas behind them are not evolutionary; they are revolutionary, reconceptualist, and postfoundational in nature (p. 122).

Although the work of Reggio educators is frequently (mis)interpreted, many schools in North American contexts continue to work toward achieving these principles and taking up the philosophy in their own contexts. In this study, I hope to build on the work of Pacini-Ketchabaw et al. which contributes to a small body of literature that critically examines early childhood practices within a Reggio philosophy and a reconceptualist theoretical framework.

\section{A Community of Learners: The Excellence Academy}

Primary to taking up Reggio principles in U.S. contexts is the acknowledgement that the approach is culturally and contextually situated (Rinaldi, 2006). Schools in the U.S. that have garnered success with the approach have not only recognized this component, they actively work to take up the principles in meaningful ways in their specific cultural contexts. More often than not, Reggio-inspired preschools in North 
America are found in affluent, suburban neighborhoods, such as those in the St. Louis Reggio Collaborative (Cadwell, 2003; 1997) and the Hilltop Children's Center in Seattle (Curtis \& Carter, 2015). However, a few examples of Reggio schools in marginalized urban areas have existed, such as the Model Early Learning Center in Washington, DC (now closed) and the Chicago preschool collaborative known as Chicago Commons (Lewin-Benham, 2006; Scheinfeld, Haigh, \& Scheinfeld, 2008). Lewin- Benham (2006) illustrates the difficulties associated with creating Reggio schools in urban settings: "Economically disadvantaged children are often stereotyped as deficient" (p. 11) and therefore not capable or deserving of a progressive approach to learning. But she speaks of the promise of the Reggio approach for reaching all children, saying, "Reggio schools, in contrast, believe all children are rich, strong, and powerful” (p. 11).

A new, rapidly-growing group of Reggio preschools in an urban area is the Excellence Academy (EA), located in a large metropolitan area of the southeastern U.S. The EA, also referred to as the Academy, is a professional development project for early childhood educators in centers in low income areas of the city and the surrounding metro area. To participate in the Academy, schools must apply and demonstrate a commitment to taking up Reggio principles in their schools and centers. These schools and centers are granted access upon meeting a demanding set of criteria. Upon joining the Academy, teachers move through a continuum of five increasingly qualified designations, beginning with Novice and ending with Master Teacher, as goals for each designation are met. Each teacher is assigned a coach and all teachers participate in Communities of Practice (CoPs; monthly professional development seminars), individual goal setting with their coaches, and continuing study and professional development in the Reggio philosophy. There are 
currently six schools participating in the Excellence Academy, with plans to include additional schools.

Accounts of successful Reggio-inspired schools in the U.S. - urban and suburban alike - consistently demonstrate that in order to achieve such success, they must stay true to their own communities and cultures. Lewin-Benham (2006) reminds us, "Schools are never isolated. They are inseparable from the culture of their time and place" (p. 10). This insight is essential as teachers work to embody the philosophies and principles of the Reggio approach: it is not about transplanting Reggio into North American contexts (Cadwell, 1997); rather, it is about taking up the beliefs about the rights of all children to authentic relationships with teachers, families, and the school environment that can be applied in any setting, urban or otherwise.

Coaches in the EA draw from the principles enacted by Reggio educators to help local teachers understand and activate the components of the philosophy. Their vision statement describes the goal of enacting "practices inspired by the Reggio Emilia approach to education" through "reflective teaching practices...positive interactions and relationships...[and] constructive, purposeful play.” Importantly, EA coaches recognize and acknowledge that as a philosophy, the Reggio approach is culturally and contextually situated, and therefore they encourage teachers to draw on the principles in ways that are conducive to each teacher's classroom, school, and community. Several components are fundamental to the Excellence Academy's expressed vision, the first of which is the collegiality developed within each center and in the larger context of the Academy. Next is the development of a network of schools in which directors and teachers share new understandings and offer support for achieving the goals of enacting research-based 
practices inspired by Reggio. There is also a strong emphasis on classroom coaching, ongoing professional development and training, evaluation, and family engagement.

Shauntá Miller-Crumes, whose classroom I described to open this chapter, is a Master Teacher in the Excellence Academy with 25 years of preschool teaching experience. The EA has influenced her teaching life over the past five years as she's learned to enact the principles of Reggio Emilia along with her assistant teacher, Tia Baker (a pseudonym). Both women are African American. Shauntá has an Associate's degree in Early Childhood Education, speaks African American English, and is considered a leader in her school. Shauntá's work with children is situated within her local context and operates within a structure consisting of myriad influences: Keystone Learning Academy and the neighborhood in which it resides; the Excellence Academy and its location, both physically and ideologically; influences of the Reggio philosophy, with special considerations for taking up the principles within the situated local context; and the influence of local, regional, and national mandates and structures within which Keystone operates as a child care center.

\section{Theoretical Framework}

I chose to approach this study through a reconceptualist theoretical lens, as it afforded me the opportunity to think beyond the narrow conceptualizations of quality, developmentally appropriate practice, and child-centeredness that dominate narratives of early childhood education in North America. In this section, I explain this theory and the constructs that are relevant to my work. 


\section{Early Childhood Education in the United States}

More often than not, conversations about early childhood education in the United States involve discussions of quality. Dahlberg, Moss, and Pence (2013) emphasize that the word is often used to indicate "best practices," but rarely are those practices identified in real and actionable ways. They say there is no clear definition of what "constitutes good quality in early childhood institutions" and that because it is frequently used without a definition, quality is "[rendered] meaningless" (p. 5, emphasis in original). This quest for quality is paired with national narratives of kindergarten "readiness," which frequently emphasize skills instruction more commonly associated with children in elementary school. Paired together, these ideas often result in demands for early childhood settings that focus on skills instruction and formal teaching in lieu of play and other child-directed activities.

For Shauntá, an emphasis on kindergarten readiness permeates her community. At both the state and local level, an emphasis on "readiness" leaves many early educators feeling unable to teach in child-centered ways. All STARS, a mandated "quality rating and improvement" system was recently adopted at the state level, meaning that in order to remain in business, every early childhood center across the state must participate in this standardized measure of "quality," independent of social, political, or economic contexts. The primary focus of the STARS system is to ensure that teachers create "high quality early learning environments" that emphasize "math, language, and social skills" (Kentucky Department of Education, 2019). Although success for all children is the goal of early educators, programs such as STARS standardizes those goals, stripping teachers 
of autonomy and creating regulatory mandates that fail to consider the wealth of cultural and social knowledge that teachers and children bring into early childhood spaces.

\section{Reconceptualizing Early Childhood Education}

The Reconceptualizing Early Childhood Education movement (RECE) began in the 1980s when early childhood scholars voiced concerns about the "dominance of psychology and child development theory" in early childhood education and began to draw from "more critical, feminist, postcolonial and postmodern perspectives in their work" (RECE International, 2014, np). Fundamental to the movement is the belief that scientific truths cannot be discovered "about any individual or group of children and then applied to all children, no matter the culture, language, belief structure, or physical life circumstances" (np). Further, the scholars who founded the reconceptualist movement challenged those in the early childhood field who promoted "universal prescriptions for 'best practice' and other 'grand narratives' which continue to dominate our field" (np). Scholars in the movement continue to advocate a new way of thinking and being with children that works against the privileging of certain beliefs or knowledges that place some in power and marginalize others. Reconceptualist scholar Cannella (1997) challenges early childhood educators to acknowledge their situated context and culture as they work to think differently about the field: "As we reconceptualize, we can function with the recognition that we are contextually grounded and are not discovering universal truths that should be imposed on all human beings" (p. 161).

Essential to the RECE movement is its critique of the National Association for the Education of Young Children (NAEYC). Due to its rigorous accreditation process and prolific publications and professional development opportunities for practitioners, 
NAEYC has become synonymous with "high quality" in early childhood spaces, including centers that serve children and families and early childhood teacher education programs in colleges of education across the nation (Copple \& Bredekamp, 2009). Although seemingly well-intentioned, NAEYC's position statement on appropriate practices relies on troubling assertions, including deficit perspectives (as revealed in their language about African American and Latinx children, those in low income households, and their explicit discussions of the "achievement gap"); steadfast reliance on child development; conflation of sex and gender; and only cursory acknowledgement of the home culture of children from diverse backgrounds. NAEYC's deficit perspectives have been critiqued for informing and perpetuating negative stereotypes and generating a view of schools populated with teachers and children of color and from low income communities as less than. NAEYC reiterates these perspectives throughout its Developmentally Appropriate Practices (DAP) manual (Copple \& Bredekamp, 2009), so teachers new to the field, including preservice teachers, are normalized into these views of children and families. Because NAEYC is the standard by which so many in the early childhood field interpret "good" practices, early childhood centers that serve children and teachers from these populations are marginalized, somehow failing to achieve "best practices" because of their social, cultural, and political locations.

I am increasingly troubled by the lack of acknowledgement of schools like Keystone that are not NAEYC accredited but consistently demonstrate quality practices within their school and the broader community. Although many of the practices in the daily life of Shauntá's classroom are in keeping with NAEYC's conceptualization of best practices, Keystone and schools like it are often considered less than because they do not 
adhere to the mandates and strictures that NAEYC deems necessary for a preschool to be considered worthy. Reconceptualist scholars (e.g., Cannella, 1997; Dahlberg, Moss, \& Pence, 2013; Pacini- Ketchabaw et al., 2015) problematize these notions, asserting that practices that fall outside of NAEYC's purview are often within the realm of "high quality" as they are situated in and responsive to their specific cultural, economic, and political contexts, and are open to multiple knowledges, truths, and ways of being with children, families, and the school and broader communities. "In a world in which equity...is of great importance, reconceptualization ...involve[s] sharing our beliefs and biases openly, respecting and valuing multiple realities and possibilities, and constructing a collective vision of action" (Cannella, 1997, p. 161).

\section{Theoretical Concepts}

I grounded this study in reconceptualist thinking, as it works to disrupt the dominant narratives of early childhood education. I drew on the following theoretical concepts to guide my work through a reconceptualist frame: feminist poststructuralism (Cannella, 1997; Davies, 2003; Langford, 2010); postmodernism (Pacini-Ketchabaw et al., 2015); and decolonization scholarship (Cannella, 1997; Souto-Manning, 2014), which are fundamental to and threaded through RECE scholarship. I wanted to better understand how these concepts functioned within the situated culture of urban Reggioinspired classrooms. I selected Shauntá's classroom as a research site because her teaching in an urban Reggio classroom offers the potential to further understandings about how the theoretical constructs foundational to RECE scholarship operate in a Reggio-inspired space. 
Feminist Poststructuralism. Davies (2003) conceptualizes feminist

poststructuralism as a construct that works to disrupt commonly held assumptions about children, noting, "it is important to recognize that individuals are constrained by existing structures and practices" (p. 13). The work of poststructuralists challenges these existing structures and practices, objecting to the notion of universal truth, and giving voice to those who have traditionally been silenced, including women, people of color, and children. The structures in place work to construct a universal truth, while poststructuralists "tend to characterize truth (e.g., reality, knowledge) as subjective, indeterminate, and created by human beings to best fit their understandings of particular contexts" (Cannella, 1997, p. 12) and as a result, multiple voices and perspectives are amplified where traditionally they have been silenced.

Postmodernism. Pacini-Ketchabaw et al. (2015) understand postmodernism as "an approach that recognizes diversity among individuals in terms of class, gender, race, sexuality, ethnicity, places of origin, abilities, and other characteristics" (p. 148). As it applies to the field of early childhood, postmodernism creates spaces for the sharing and valuing of multiple diverse perspectives. Dahlberg et al. (2013) stress that from a postmodern perspective, "the world and our knowledge of it are seen as socially constructed" and "as human beings, [we] are active participants in the process [of social construction]" (p. 24, emphasis in original). In this way, a postmodern perspective offers a space for new knowledges to be shared by all participants in a community and not just those who have traditionally been privileged.

Decolonization. "The belief that child development universally describes" all children "denies the multiple realities of children's lives" (Cannella, 1997, p. 59). 
Cannella calls for the decolonization of our views of early childhood education, as these views privilege White, middle-class children and teachers, informing a deficit perspective of any children that fall outside of the privileged few. Souto-Manning (2014) also calls for the decolonization of the language used to communicate within and about the early childhood field. She believes early childhood educators are colonized when they do not question or challenge the dominant narratives of the field. She maintains that teachers are “colonized by oppressive discursive practices, or at least [employ]...institutional discourses to justify their oppressed experiences and locations" (p. 172).

\section{Reconceptualizing Children}

Poststructuralism, postmodernism, and decolonization open up the ways in which children and childhood are understood, moving beyond a reliance on child development as the only means for understanding children's growth. Through these lenses, reconceptualist scholars work to rethink and reframe the early education field, reimagine early childhood practices, and disrupt assumptions about children, childhood, and the field of early childhood education. Cannella (1997) believes that Eurocentric perspectives dominate the field of early childhood education through the privileging of child development and child psychology contexts. The result, she believes, is a "globalized child" that creates a privileged few and marginalizes those outside of the Eurocentric ideal. She states, "Child development has ethnocentrically institutionalized a global child in the image of the Euro-American middle-class" and that "children from cultures that are not Euro-American and those who are poor are automatically placed in the margin. Their unique knowledges, skills, abilities, and views of the world are denied" (p. 93). 
Reconceptualists "have proposed that the knowledge base used to ground the field actually serves to support the status quo, reinforces prejudices and stereotypes, and ignores the real lives of children (and other human beings such as their parents and teachers) ...” (Cannella, 1997, p. 1). Broadening perspectives to include those outside of the Euro-American reliance on child development and psychology enables early education professionals to critique these perspectives. Without careful critique of the field, "we risk excluding human beings whose lives do not mirror the dominant view of early childhood; and we place limits on ourselves and the children with whom we interact" (Cannella, 1997, pp. 1-2).

\section{Reggio as Compatible with Reconceptualist Thinking}

Reconceptualist scholarship, as a framework, can help Reggio scholars and practitioners realize and give language to the philosophy as it is enacted. The pedagogical and curricular practices embodied by Reggio educators contest the dominant narratives common in early childhood education, especially those in North American contexts. At its most basic, the Reggio philosophy understands children as competent and capable, a perspective that starkly contrasts with U.S. sensibilities of children as innocent, needy, and requiring adult protection (Cannella, 1997). As such, Reggio principles are in harmony with reconceptualist thinking, which challenges those notions through the values inherent in the philosophy: children are the protagonists of their own learning, with the same rights as adults. Davies' (2014) reconceptualist research in a Reggioinspired preschool in Sweden indicates that children are agents in Reggio spaces; that is, they have "the power to engage with others in ways that open up the capacity for thought and being..." (p. 9) and that children with agency are "ethical subjects...listening in ways 
that enable the not-yet-known to emerge" (p. 6). Davies argues that community is established through the "mutual engagement of children with each other, with adults, and with their material environment" (p. 6).

In many ways, as they have been practicing poststructuralism and drawing from a wide variety of progressive theories since the schools were founded in Post-World War II Italy (Gandini, 2012a), the educators of Reggio Emilia have been enacting a reconceptualist stance since the inception of the approach. "Developmental theories are only one of many influences on Reggio... Reggio leaders have understood that no theory is the absolute truth, and that every theory is just a starting point for further investigation and discussion” (Pacini-Ketchabaw et al., 2015, p. 122). Like Reggio educators, reconceptualists work to "unsettle our ways of viewing children and the roles of early childhood educators" (p. 4).

Because the thinking of Reggio educators and reconceptualist scholars is so compatible, this theoretical framework afforded me the language and constructs necessary to navigate the practices put into action by Shauntá as situated within the Excellence Academy. This compatibility anchored my thinking as I strove to understand what I came to see as pedagogies in Shauntá's classroom and address the philosophical nature of the Reggio approach. My aim is for my dissertation to contribute empirical data to RECE scholarship and speak back to dominant North American narratives that otherwise limit the work of Shauntá and teachers like her.

\section{Research Questions}

My professional relationship with Shauntá began in the fall of 2016, when I was assigned to her classroom as a research assistant in a study called, "Documenting Stories 
on the Journey Toward Excellence" (Whitmore, 2018). Over the two years that followed, Shauntá and I got to know one another through the research activities I undertook, including classroom observations, interviews, and other formal and informal interactions. Our relationship deepened as we worked together, particularly as we traveled and presented at conferences with other members of the research team. After more than two years of these activities, I had musings about Shauntá's practices. What changes had occurred since my initial visits to the center? A period of intensive fieldwork at the beginning of this dissertation led me to develop the research questions that are the basis of this ethnographic study. I was interested in learning what curricular and pedagogical moves Shauntá made as she worked with the children in her classroom community: How did she enact the identity of a Reggio teacher? What pedagogies were consistent across time and setting? To better understand how Shauntá enacted various pedagogical moves in her teaching, the questions guiding this inquiry were:

1. What pedagogies are evident in Shauntá's classroom as she enacts the identity of a Reggio teacher?

2. How are these pedagogies enacted across time and events as she interacts with the children in her classroom?

3. Why are these pedagogies important in the current political climate? In this chapter, I outlined the theoretical framework through which I conducted my study. In Chapter 2, I review other relevant reconceptualist studies, as well as literature that illuminates the pedagogical work Shauntá enacted in her classroom. In Chapter 3 I describe the methodology and methods for this study, with a focus on the feminist ethnographic approach that is consistent with tenets of reconceptualist theory 
and Reggio Emilia philosophy. I present the findings from my study in Chapters 4, 5, and 6: the pedagogies of time, inviting, and documenting. I conclude the study in Chapter 7, where I also reflect on the relationship I came to value and trust with Shauntá and offer implications for future research and practice. 


\section{CHAPTER TWO: \\ REVIEW OF LITERATURE}

\section{Introduction}

The purpose of this study was to understand one preschool teacher's pedagogical moves in an urban Reggio-inspired classroom, and how those moves were enacted across different classroom settings and events. Empirical research about Reggio classrooms is scant. Although there is much literature available about different facets of the Reggio philosophy, including the North American Reggio Emilia Alliance (NAREA) journal Innovations, there is little empirical research about Reggio practices available. I believe this lack of empirical literature is due to the way the Reggio approach is conceptualized: as a philosophy. I begin this review with two accounts of Reggio-inspired schools in urban settings that demonstrate the challenges and affordances of Reggio-inspired pedagogy in North American contexts. I then review the concept of pedagogy in early childhood settings. Next, I discuss a sampling of reconceptualist studies, and literature pertaining to key early childhood education concepts that emerged in my analysis as significant: time, curriculum, documentation, and learning stories.

\section{Reggio in Urban Spaces}

Although not an empirical study, Lewin-Benham's (2006) Possible Schools details the journey of one preschool in Washington, DC on its way to enacting Reggio practices. Lewin-Benham recounts the challenges associated with attempting this 
progressive approach in the urban core of the city and the many obstacles that accompanied her mission to embrace Reggio practices. "Unfortunately, fallacious racial or social stereotypes constrain expectations for what some children can accomplish even though we know that each young child who is at risk because of poverty has the same potential as any other child" (p. 1). The result is an honest narrative account of how the Model Early Learning Center (now closed) moved from traditional, structured approaches to early education to embracing the Reggio philosophy and demonstrating that children everywhere are capable and deserving of such an approach. Possible Schools is an important example for other schools working to enact Reggio principles, especially those situated in urban spaces with similar challenges and populations.

Scheinfeld, Haigh, \& Scheinfeld's (2008) We Are All Explorers, offers an account similar to Lewin-Benham's, this time situated in a Head Start program collectively referred to as the Chicago Commons. This book documents the 12-year journey of Chicago Commons teachers and administrators as they worked to understand and then enact the Reggio approach in their urban neighborhood. Although there are troubling omissions in the book, such as the authors' choice to disregard cultural and social realities of the schools' populations, it is significant in that it demonstrates that the road to taking up Reggio principles is a challenging one. Additionally, it offers very practical accounts of how other schools might take the lessons learned there and apply them in other spaces.

These works contribute anecdotal narratives and historical documentation to the limited body of work pertaining to the Reggio Emilia philosophy as it is enacted in urban settings. However, I was especially interested in addressing questions about the specific 
social, cultural, and political location of Shaunta Miller-Crumes' work within the context of her school and neighborhood, including an ethnographic look at the pedagogies she enacted with her preschool learners and the interactions that took place in her classroom. This study illuminates how one teacher understands and embodies the Reggio approach in a specific urban context and how that understanding is enacted.

\section{Reconceptualizing Early Childhood Education}

This study is situated in a reconceptualist framework. Broadly, the work of reconceptualist scholars demonstrates "new directions in ways of imagining and understanding childhoods, rethinking early childhood education and care" and advocating for "how early education, and child care theory, policy, pedagogy, and curriculum might be re-imagined" (Bloch, Swadener, \& Cannella, 2014, p. 1). Reconceptualist scholarship works to disrupt the narratives common to early education and care, particularly the notions of developmentally appropriate practice and child-centeredness as defined by the National Association for the Education of Young Children (NAEYC) (Copple \& Bredekamp, 2009). Reconceptualist scholarship encompasses a broad spectrum of studies that problematize notions of power as related to gender, race, class, and other identities as defined and perpetuated by NAEYC (and others).

An example of a study that problematizes developmental views of gender and gender performance is Blaise's (2005) study of what she terms the "heterosexual matrix" in an early childhood classroom. Her study, situated in a kindergarten classroom, draws on feminist poststructuralist and queer theory to interrogate how gender is created, taken up, and performed by the children in the class. By closely watching and listening as children play, talk, and engage in school activities and recess, Blaise makes visible the 
gender performances children take up and exercise in bids for power, attention, and control, and the "category maintenance work" she observes as children strive to understand which gendered behaviors are appropriate for themselves and others. She identifies five heterosexual discourses - wearing femininity, body movements, makeup, beauty, and fashion talk - and demonstrates in case studies how two children's gender performances aligned with the heterosexual matrix, while a third child attempted to "find other... more liberating discourses to engage with" (p. 184). Blaise asserts that poststructuralism and queer theory "[open] up new ways for listening to, observing, and interpreting children's talk and actions in the classroom" and that these “postdevelopmental perspectives can assist us to conceptualize gender as a social, historical, cultural, and political construction, and to recognize that young children take an active part in their gender construction" (pp. 183-184).

Similarly, Ryan (2005) used a case study approach to examine children's experiences during choice time. By closely analyzing the talk and bodily movements of two children, Ryan identified how each child attempted to negotiate, contest, and maintain power relationships within their peer groups. Using either verbal or physical strategies, each child worked to gain access into social groups, where they attempted to gain and maintain power over their peers in a bid for inclusion, sometimes manipulating peers through use of taboo language. Using a poststructural lens to analyze descriptive data of "children's talk and action during choice time over a five-month period" (pp. 101102), Ryan concludes that “children's play is not a neutral space but rather is a political and negotiated terrain" (p. 112). She suggests that child-centered approaches - where teachers relinquish their authority in deference to children's independence - often result 
in scenarios where one or two children grab for power at the expense of excluding others. Ryan challenges early childhood practitioners to reconsider child-centered education in favor of "educational equity [that] poses new challenges and possibilities for those of us in early childhood education" (p. 112).

\section{Pedagogy}

Pedagogy, as a concept, is complex and often difficult to define. Stephen (2010) conceptualizes pedagogy as "art or craft, changing and adapting to the context and individuals involved" (p. 2), while López (2017) and Morrison (2017) add that assetbased pedagogies draw on the cultural and familial knowledges children bring into the classroom. I align with the asset-based definition of pedagogy as offered by López and Morrison, and I believe that Stephen's idea of changing or adapting in response to context and individuals encompasses the asset-based idea.

Stephen (2010), in her study of the pedagogical beliefs of early years teachers in the United Kingdom, found that many early years teachers have difficulty articulating what pedagogy is, and therefore are unable to recognize or name the pedagogical practices they enact in their work with children. Therefore, she refers to pedagogy as the "silent partner" in early childhood education. She identifies two "big ideas" consistent in the talk and practice of early years teachers: child-centeredness and play. Stephen determined that some of the pedagogies put into place by early years teachers are inconsistent with their stated beliefs. She found that it was "easier for practitioners to engage in discussions about particular pedagogical actions or interactions than to articulate their pedagogical perspective" (p. 12). She attributes this to the theory/practice gap and calls for researchers and practitioners to engage in critical conversations about 
both theory and practice, which she believes will encourage early years teachers to engage in reflective practices that will benefit teachers and children alike.

The concept of pedagogy in early childhood education has strong ties to reconceptualist scholarship. Teachers who embody a reconceptualist stance make intentional pedagogical moves that position children as experts of their own existence, and as vital contributors to their learning, both inside and outside of formal school settings (Cannella, 1997). In this study, I sought to better understand the pedagogical moves Shauntá made as she interacted with children-whether consciously intentional or not.

\section{Time in Early Childhood Classrooms}

Reconceptualist scholars such as Pacini-Ketchabaw (2012) challenge the over-reliance on clocks that dictates children's and teachers' lives. Often in early childhood environments, “the clock [shapes] educators' practices and [regulates] children's schedules; time [dominates] daily practice" (p. 155). Because "the clock defines, regulates, schedules, organizes, and synchronizes lives," it is difficult to imagine an early childhood space where attention to time is not an explicit pedagogical consideration (Pacini-Ketchabaw, 2012, p. 157).

Given that the "clock is fundamental to how early childhood education is understood, organized, and enacted" Pacini-Ketchabaw (2012, p. 155) considers time in early childhood classrooms through a posthuman lens, meaning she considers the materiality of clocks and their effect on children and educators. She seeks to understand how time is constituted and reconstituted through what she labeled "early childhood clocking practices" (p. 155). She paid strict attention to the classroom clock to see the 
ways it influenced the teachers and children at various points of the day. She took copious fieldnotes, paying special attention to when teachers moved (for example, from facilitating an activity with children to leaving the classroom for a break) and children transitioned, and how frequently teachers used the clock as a means of soothing children who missed their parents. She concludes that in many early childhood settings, "the clock [shapes] educators' practices and [regulates] children's schedules; time [dominates] daily practice" (p. 155).

Similarly, Wien and Kirby-Smith (1998) wondered what would happen if clocks were removed from early childhood classrooms altogether. Having worked in early childhood settings for more than 20 years, they noticed a shift from flexible daily schedules that responded to children's needs to a more structured, "production-schedule organization of time" (p. 8). In an attempt to disrupt teachers' strict reliance on clocks, they removed them from the classroom and asked the teachers not to wear watches. "The order of events would remain unchanged for the children's sense of security. However, the timing of changes in activity would be decided according to cues from the children, gathered from teachers' observations" (p. 9). Although initially the classroom teachers expressed their discomfort with the absence of clocks, eventually they came to view the absence as liberating, citing the children's needs as more important than their comfort and control of the classroom in response to the clock. This timing experiment, while started in only one classroom, had a ripple effect throughout the rest of the center. Teachers agreed that clocking practices were in response to their own desire for control, rather than out of consideration for what was best for children. Wien and Kirby-Smith ultimately addressed this desire by encouraging teachers to think deeply about their 
clocking practices, saying, "Tightly timing the program gives teachers extra power. Why not try to give the children a little more ownership of their own day?" (p. 13).

\section{Curriculum in Early Childhood Classrooms}

Empirical studies that specifically address invitations to learn are rare. An exception to this is a study by Heydon, Crocker, and Zhang (2014), in which the authors examined emergent literacy production in a child care center as enacted through provocations inspired by children's interests and the books they were consuming. The researchers observed as teachers introduced provocations in response to children's interests, noting that many times, unintended provocations appeared in response to unplanned moments in the life of the classroom, such as one child bringing in a tadpole for observation. Because the teachers viewed children as an integral part of informing curricular decisions, children were invested deeply - a change from cursory engagement under previous curricular models. When teachers specifically provoked children through literature and other meaningful classroom events, Heydon, Crocker, and Zhang noted that the curriculum was richer and that children had ownership over their learning, concluding that "emergent orientations" to curriculum "invite prolific input by children" (Heydon, Crocker, \& Zhang, 2014, p.4).

Kashin's (2007) dissertation study, while not specifically about invitations to learn, used a narrative inquiry framework as she evaluated her journey as an early childhood educator and the professional journeys of four early childhood teachers who successfully moved from theme-based curricula to authentic, emergent curricula based on children's interests and knowledges. Through interviews, observations, focus groups, and the use of metaphors to describe teaching practices, Kashin documented the journey of 
four teachers as they shifted their pedagogical practices from structured, themed units to an emergent curriculum framework. Through case studies, Kashin shared the narratives of the four teachers, as well as her own journey, as they began to teach in the "Reggio way" (p. 167). In taking up emergent curriculum, Kashin and the other teachers came to understand emergent curriculum as a way to advocate for a strong image of the child, and also as a means for advocating "a new image of teachers and teaching" (p. 167). Because emergent curriculum relies on providing opportunities for children to inquire about the world and for teachers to share control with children as learners, Kashin learned that ultimately it was a means for teachers and children to work together in a true coconstruction of new understandings and knowledges. Kashin calls emergent curriculum a democratic practice, one that fosters collaboration and "allows for the voices of others, even if they produce conflicting perspectives" (p. 251). This, she believes, is at the heart of emergent curriculum: "Teaching and learning in an emergent way empowers both children and teachers" (p. ii) because all voices are heard, all perspectives are valued, and all participants are open to new understandings.

\section{Documentation in Early Childhood Classrooms}

Reggio founder Malaguzzi states that in Reggio schools, “...the walls are used as spaces for...exhibits about what the children and teachers have created: our walls speak and document" (cited in Gandini, 2012, p.41). This documentation is an integral component for enacting the work of "making children's learning visible” (Rinaldi, 2006). In spaces where documentation records and informs, the walls are alive with the children's thinking, the teachers' observations and provocations, and the collective history of meaning making and the co-construction of knowledge. Collectively, 
documentation is viewed as a narrative of the children's, teachers', and school's contributions to the wider community (Dahlberg, 2012).

Scholars working in Reggio-inspired spaces have detailed the myriad ways in which documentation contributes to meaning-making for children, teachers, and others. Because of its fluidity and flexibility, the practice of pedagogical documentation can be taken up in myriad ways and for diverse purposes, as evident in the studies I discuss here. Narrative in nature, the studies work to understand who benefits from pedagogical documentation, what insights it offers, and how it is taken up by teachers and children.

In an observational study, Paananen and Lipponen (2018) used teacher-generated documentation and individualized child learning plans displayed as documentation panels to demonstrate how intentional, reflective documentation helps to amplify the voices of children and teachers. They studied pedagogical documentation as "an attempt to construct social reality" (p. 78) to invested parties (teachers, children, and families). To understand the perceptions of that documentation, they observed as teachers, children, and families interacted with one another in response to the documentation. They then engaged a teacher study group in which participants took up the practice of pedagogical documentation to foster stronger relationships with families. Paananen and Lipponen support the practice as a means for illuminating families to how children spend their days at school and to demonstrate the practices in which children engage. Pedagogical documentation offers "a more nuanced discourse on quality ECE (early childhood education) [and focuses] on perspectives of equality" (p. 77). Paananen and Lipponen conclude that pedagogical documentation is a tangible means for inclusivity and for amplifying multiple knowledges and ways of knowing. Through pedagogical 
documentation, teachers in the study fostered relationships with the parents of their students through documenting and sharing existing practices. The records of pedagogical documentation were used as supporting documents when parents, teachers, and children came together to create individualized education plans for each child (a routine practice in their setting). The presence of documentation - and its use for informing the creation of the plans - encouraged parents and children to take an active role in the direction of the children's early education experiences, a practice uncommon in most early childhood settings.

Clark (2010) used documentation to understand how the perspectives, insights, and interests of children under six years of age can be "given status in processes of change" (p. 115). Her study examined the ways in which teachers engage children through participatory and visual methods. Using the Mosaic approach, in which children are given cameras and encouraged to take photos and then tell stories about them, Clark demonstrated the ways in which children were invited into the documentation process, and how photographs taken by children, as well as their narrations of the photos, offered new insights into children's meaning making and construction of knowledge. Further, it illuminated for teachers the power of inviting children to be active participants in the documentation of their learning and meaning making. "This documentation can make children's perspectives visible in a way which can open up conversations with peers, practitioners, researchers, and parents" (p. 117). When children are the facilitators of documenting and sharing their experiences, the practice becomes democratic, wherein children's "voices are more visible" (p. 121). 
Kline (2008) describes pedagogical documentation as "a tool that helps teachers in Reggio Emilia schools develop flexible, yet comprehensive curriculum plans that are respectful of children" (p. 72). Kline used the study of pedagogical documentation with preservice teacher candidates to demonstrate the ways in which "making learning visible" contributes to the overall quality of a program. The study emphasized family investment in reading and understanding panels, encouraging teachers to closely watch and document children's learning for better understanding of the learning process, and analyzing children's meaning making to craft meaningful curricular opportunities in response. Importantly, for the teacher candidates in Kline's study, "the most overwhelming benefit of the documentation panel was that it could be shared with parents and administrators as evidence of learning" (p. 76) in an authentic manner not typical of many early childhood settings.

Millan (2012) notes the significance of pedagogical documentation in her understandings of preschool-aged boys' pretend play with gender. Her study used photographic documentation as a research tool in order to "understand the extraordinary in the ordinary" as she worked to discern the ways in which boys experimented with gender during their pretend games on the playground. Although her study did not focus specifically on pedagogical documentation as a subject, Millan found it to be imperative in her understandings, as she worked to make sense of the significant moments on the playground amid the typical hustle and bustle of outdoor play. Working with two sets of photos, Millan and her "documentation partner" - the teacher in the classroom where the study took place - closely analyzed the photos in search of new meanings and understandings, eventually developing themes from the photographs and using those 
themes to further analyze the documented moments. "When documentation is viewed as a research methodology, it serves the purposes of many groups of people..." (p. 4).

\section{Learning Stories in Reggio-Inspired Early Childhood Classrooms}

One form of pedagogical documentation common in Reggio-inspired spaces is Learning Stories: stories written to, rather than about, children "based on [teachers'] observations that reveal new insights into children's perspectives" (Curtis \& Carter, 2013, pp. 9-10). Curtis and Carter describe that many teachers "write them directly to the child, which some people have characterized as akin to a love letter. This brings [the educator's voice] into the story powerfully, always conveying a sense of how competent children are" (p. 254). Developed in New Zealand by early educators Margaret Carr and Wendy Lee (2012), Learning Stories are intended as an alternative to standardized assessments as a means for documenting how learning identities are constructed over time.

As the use of Learning Stories has become more prevalent in early learning settings in New Zealand and other countries, there has been an increase in scholarship questioning exactly what it is that Learning Stories are accomplishing for children and families, and what the information they provide reveals about children's learning in early childhood. Blaiklock (2013), for example, sought to answer the question, What are children learning in early childhood education in New Zealand?, citing Learning Stories as one source available for pursuing an answer. He determined, ultimately, that he could not find a satisfactory answer to his question, stating that educational documents, including Learning Stories, "all fall short in providing evidence about what children are 
learning" (p. 54) and emphasizing that Learning Stories, in particular, are meant to assess dispositions to learning but that the dispositions "have not been clearly defined" (p. 52).

Many early educators, however, counter this stance, asserting that Learning Stories offer two benefits as they strengthen relationships between teachers and children. Carter (2010) asserts that not only do Learning Stories offer "a way to assess desirable outcomes [in children], but... [they] strengthen practitioners' ability to use documentation as a tool for their own learning and teaching" (p. 40). When teachers engage in interpreting Learning Stories, they demonstrate their knowledge and expertise, while also taking ownership of that expertise. Similarly, Hanrahan, Niles, and Whyte (2019) advocate the use of Learning Stories as a way of "[capturing] children's complex learning" and acting as a "catalyst for discussions about learning from other members of the learning community" including "children, parents, family,... and other teachers" ( $p$. 12). Those who believe in Learning Stories as a way to communicate children's complex learning in narrative form make the case for stories as a means of demonstrating the possibilities of divergent assessment, that is, "assessment [that] is accomplished mainly via a collaboration between and amongst teachers and students" (Carr \& Lee, 2012, p. 25).

\section{Conclusion}

This body of scholarship indicates that while much is known, studied, and understood in early childhood research based in reconceptualist and Reggio Emilia ideologies, much is yet to be learned. A notable gap in the research literature is feminist ethnographic research in urban Reggio-inspired classrooms where children and their teachers are likely to be framed by deficit beliefs about their current practices and 
potentials. Thus, the scholarship reviewed in this chapter inspired and informed the design of my work in Shauntá's classroom and provided me a context and history within which to make methods decisions. In the next chapter, I provide a methodological rationale for my study, and describe the study design, data collection, and data analysis methods I used to learn how Shauntá enacted pedagogies of possibility in her interaction with preschool children. 


\section{CHAPTER THREE: \\ METHODOLOGY}

The purpose of this study was to understand the pedagogies enacted by one preschool teacher in an urban Reggio-inspired classroom across time and classroom events. This study sought to understand how these ideas could be understood within a reconceptualist perspective. My researcher gaze is feminist and reconceptualist in nature and methodology; these lenses framed my work to understand the pedagogical moves the teacher made in her Reggio-inspired preschool classroom.

\section{Research Questions}

Shauntá Miller-Crumes teaches at Keystone Learning Academy, a preschool and child care center located in our city's lowest-income housing project. Shauntá's school is part of a professional development community known as the Excellence Academy, which supports teachers as they work to become Reggio-inspired in their own practices. As I explained in Chapter One, I was a researcher in Shauntá's classroom for nearly three years. In the dissertation phase of our work together, I explored more deeply some of the facets of her practice. I was interested in learning what curricular and pedagogical moves she made as she worked with the children in her classroom community. To better understand how Shauntá enacted various pedagogical moves in her teaching, the questions guiding this inquiry were: 
1. What pedagogies are evident in Shauntá's classroom as she enacts the identity of a Reggio teacher?

2. How are these pedagogies enacted across time and events as she interacts with children?

3. Why are these pedagogies important in the current political climate?

In the remainder of this chapter I explain my feminist methodology and the design, data collection methods and analysis methods I used in the study.

\section{Feminist Methodologies}

Ahmed (2017) asserts that "[feminism] is not something we can put down.

Feminism goes where we go" (p. 15). I brought my feminist beliefs into my research and work with Shauntá and the children in her classroom. Engaging in research through a feminist methodological stance entailed working toward more equitable relationships and supporting those who are not consistently supported by the systems we live within (Ahmed, 2017), particularly traditionally marginalized identities. In my research, participants were women, people of color, and early childhood educators, all markers of marginalized identities.

I was an early childhood teacher for 12 years and worked to enact the Reggio philosophy in four different settings. Although three of these settings were affiliated with a college or university and therefore benefitted from diverse student and teacher populations, none of those experiences afforded me the opportunity to work in a setting quite like Keystone Learning Academy. Having worked in Reggio-inspired spaces in the past, I felt closely connected to and interested in the work that Shauntá did in her classroom. For this reason, I was diligent in my awareness of how my own knowledge 
and teaching experience might influence my observations. I also worked to remain attentive to any ethical challenges that might arise, particularly the urge to insert myself into the events of the classroom or to offer unsolicited advice or opinions. Rather, I remained open to opportunities for collaboration at Shauntás invitation.

I strove to maintain a trusting relationship with Shauntá, acknowledging that I needed to remain cognizant of power relationships, value multiple and diverse perspectives, and actively maintain my stance as an ally to Shauntá and others who are traditionally marginalized. These intentions were consistent with my reconceptualist theoretical framework. Davies (2014) cautions, "There is a tendency we all have to think in terms of categories and of entities that fit into those ready-made categories" (p. 7). This caution was important as I organized my thinking; in the planning of this study I thought explicitly about my theoretical stances and influences. Taking up feminist poststructural perspectives, I chose to use methods used that centered Shauntá's voice (Cannella, 1997; Davies, 2003), relied on multiple interpretations of events (PaciniKetchabaw et al., 2015), and resisted the construction of a universal child and of early childhood educators (Cannella, 1997; Souto-Manning, 2014).

Centering Shauntá's voice also meant valuing and preserving the way she spoke. Shauntá is a speaker of African American English (AAE) and I worked to preserve her speech in transcriptions to represent her accurately and to value her voice. I agree with Green (2002) (and other scholars) who asserts that AAE is not a "degraded version of classroom English" (p. 1). Since I did not intend to engage in a linguistic analysis of any of the speech in the data, I did not include every hesitation, interruption, or repetition in the transcription. Rather, I focused on the content of what Shauntá said and represented it 
to the best of my ability as she said it. I did, however, consider and try to represent the context of her speech. I also chose to represent our conversations and the conversations between Shauntá and other speakers in conversational formats that reflected the nature of relationships as well as words.

I acknowledge that "the shape of knowledge is always changing" (hooks, 2010, p. 10) and I worked to respond to that constant change through collaboration with Shauntá by sharing, talking, questioning, and intentionally creating opportunities where she and I had time and space to reflect on events from her classroom and consider multiple interpretations. Because of the flexible and fluid nature of the Reggio approach, I anticipated many surprising moments to explore as I spent more time in the classroom. I attended to emergent curriculum, classroom environment, and documentation - three foundational tenets of the Reggio philosophy that I was initially interested in - but remained open to other facets of classroom practice as well. Soon, I closely watched the pedagogical moves Shauntá made as I continually reflected on how this progressive approach to early childhood education was enacted within the specific urban neighborhood in which Keystone Learning Academy thrives. Taking up a reconceptualist frame positioned this study in a Reggio-inspired preschool classroom to contribute to the body of literature that reimagines children, childhood, and early educators.

\section{Positionality}

I am a White woman who grew up in a middle-class home in a small rural community in central Illinois. Although I have now lived and worked in diverse settings that have brought me into close relationships with people of color, the first eighteen years of my life were spent in an almost exclusively homogenous White farm town. During the 
twelve years I was a classroom teacher, I developed relationships with many children of color and their families, but it wasn't until much later in my life that I had close friends and colleagues of color.

This brief history is an important acknowledgment for how I now navigate research settings in which I am an outsider. I recognize that I am not always privy to cultural norms and may be surprised by what I encounter in a space as an outsider. I recognize that I am still learning about Shauntá's community and those like it, and I work to be cognizant of that fact as I pursue inquiries as a White researcher in a Black community.

Scheurich and Young (1997) identify five categories of racism and their effects on educational research: overt and covert racism, which they state operates at a personal level; institutional and societal racism, which operate at the institution and social levels; and civilizational racism, which constitutes and informs the previous four categories. They warn that by being unaware or unwilling to acknowledge these different categories "restricts our understanding of racism to an individual ethical arena" and is "a barrier to a broader, more comprehensive understanding of racism - for society and for researchers" (p. 5). They assert that using coded terms such as "culturally disadvantaged" or "cultural deprivation" to describe the success (or lack of success) of students of color is a form of institutional racism, one that researchers must acknowledge if they are to consciously work toward an anti-racist research stance. In order to disrupt racism in research settings, Scheurich and Young implore the initiation of a "rigorous debate/dialogue among scholars of all races" and in particular, center the scholarship of people of color, thus "[legitimating] the research epistemologies that arise out of the social histories of people 
of color" (p. 11). These considerations are an essential component of my work as I navigate research in a Black community as a White woman.

\section{Study Design}

This study was designed in three overlapping periods. I drew on a total of approximately three years of data collected in Shauntá's classroom. During the first two years, I visited Shauntá's classroom about once a month to observe naturally occurring classroom activities and interview Shauntá. My dissertation study began in December 2018. I spent the first period (about four weeks) analyzing more closely the data I collected during the first two years. This included fieldnotes from nine classroom observations and four semi-structured, formal interviews with Shauntá. Period 2 was ten more weeks of intensive fieldwork when I was in the classroom one to two days a week for about one hour per visit. Data collected during this ten-week period included eight sets of descriptive fieldnotes from participant observations; transcripts of seven informal interviews with Shauntá; and five Learning Stories I shared with Shauntá about her teaching, which are described at length below. Although data analysis was an ongoing process throughout Period 2, in Period 3 I focused specifically on answering my research questions, drawing on each of the data sources from all periods of the study to create a robust picture of classroom practices and Shauntá's pedagogical practices and thinking. A full discussion of data analysis appears later in the chapter. Figure 3.1 illustrates the study timeline and research activities for the study. 


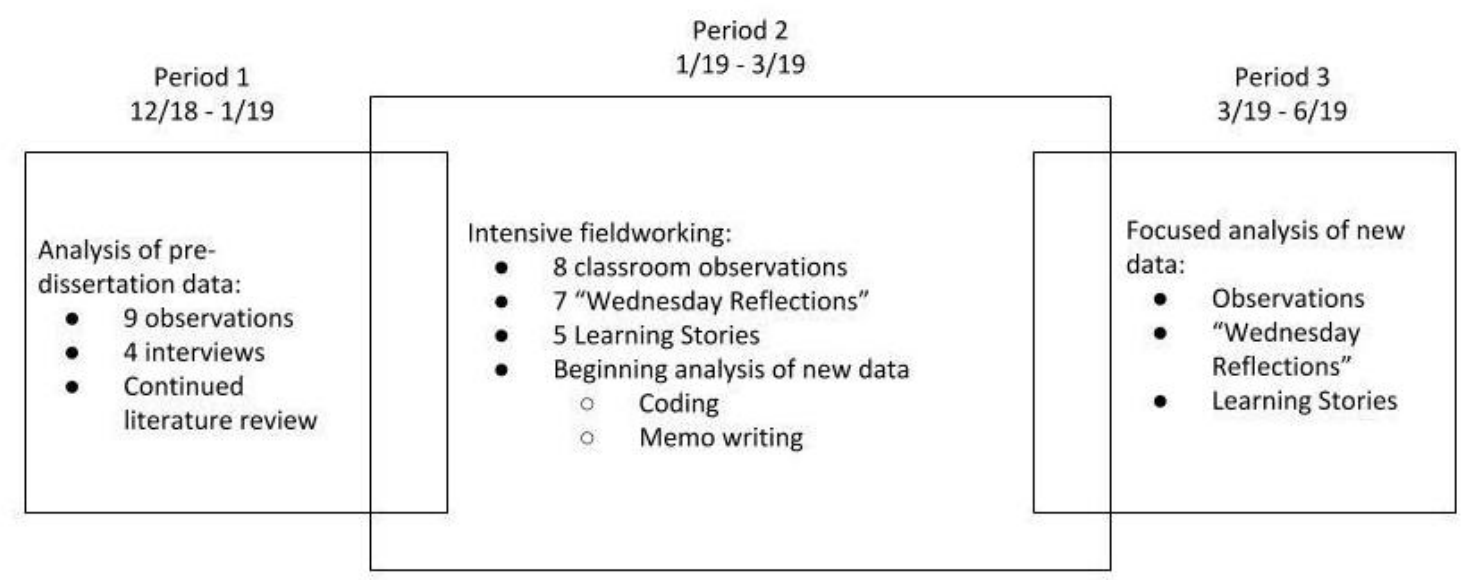

Figure 3.1. Timeline for dissertation data collection and analysis.

All data compiled during the study was organized chronologically for analysis. See Table 3.1 for a summary of the data collected.

\begin{tabular}{|l|c|}
\hline \multicolumn{2}{|l|}{ Data Collected } \\
\hline Classroom observations & 17 \\
\hline Interviews and Wednesday Reflections & 11 \\
\hline Learning Stories & 5 \\
\hline
\end{tabular}

Table 3.1. Data summary for the current study.

Feminist Ethnographic Methods

Harding (1987) says that feminist methodologies require "new uses of familiar research techniques" (p. 2) and calls for methodologies that give voice to women's experiences. Using familiar ethnographic techniques, such as observation and interview, this study gives voice to Shauntá's experiences as a Reggio teacher, as well as to my experiences as a researcher. This methodological stance enabled me to focus on our experiences as co-constructors of new knowledges. 
Ethnographic methods afforded me the flexibility to enter Shauntá's classroom with specific areas of interest, while remaining open to the possibility of developing new questions. Sunstein and Chiseri-Strater (2012) use the term fieldworking to describe the "gathering, interpreting, and validating [of] data via notetaking, interviewing, ... and other methods" (p. 416). The skills involved in fieldworking - "looking, listening, collecting, questioning, and interpreting" (p. 1) - were an important feature of my previous work in Shauntá's classroom, and continued to be so as I spent more time in the space and became a more consistent presence in the classroom.

I made decisions about methods in response to classroom events as they took place. I took descriptive fieldnotes by hand during each observation, which I then expanded upon my exit from the classroom. I also relied heavily on the use of my iPhone to take photographs of the classroom space, documentation panels and displays, and Shauntá and the children as they actively worked in the classroom. Tobin, Hsueh, and Karasawa (2009) highlight video recordings as a way to construct a record of prolonged classroom activity, those moments that can be difficult to represent through handwritten notes alone. I also used audio and video devices to record active events in the classroom for further analysis and to afford me the opportunity to return to those events multiple times, particularly those that involved children describing documentation or interacting with Shauntá.

\section{Participant Observations}

In January 2019 I began a period of intensive observations and observed the life of Shauntá's classroom over the course of ten weeks. Rather than systematically scheduling observations in advance, I planned observations in response to Shauntá, the 
children, and developments in the culture of the classroom on a weekly basis. During observations, I worked to remain open to anything that might materialize in Shauntá's classroom, but I specifically attended to her interactions with children. There were always many things going on in the classroom that didn't fit the focus of the study. When I left the classroom, I immediately expanded the handwritten fieldnotes in a word document and answered the reflective prompts that comprised my fieldnote protocol, as applicable for each observation. These prompts, adopted from Sunstein and Chiseri-Strater (2012) were: What surprised me? What disturbed me? What intrigued me? See Appendix A for the fieldnote protocol.

Consistent with a feminist and reconceptualist framework, I was determined to remain aware that my observations were comprised of my own perspectives and interpretations of what I saw during each visit and how I conveyed what I perceived in writing. Feminist poststructural perspectives critique the concept of a single version of Truth (Blaise, 2005; Davies, 2003) and because I align with this perspective, I worked to remember that I was collecting information to tell one of many possible stories from my participant-observer perspective.

\section{Semi-Structured Interviews}

I conducted four semi-structured interviews with Shauntá over the first two years of fieldwork in her classroom. Merriam and Tisdell (2016) emphasize that semistructured interviews are a common component of qualitative research, as "the interview is guided by a list of questions or issues to be explored" (p. 110) rather than a narrow set of predetermined questions that often don't allow “access to participants' perspectives and understandings of the world” (p. 109). During those interviews, Shauntá and I 
discussed topics such as her teaching journey, her perspectives on classroom environment, and her experiences in the Excellence Academy. Transcripts of these formal interviews were included in my data analysis. See Appendix B for interview protocols.

\section{Wednesday Reflections}

During the intensive period of fieldwork, in lieu of formal interviews, Shauntá and I met regularly for intentional but informal conversations. We met for 30-60 minutes on Wednesday afternoons in what we came to call "Wednesday Reflections." These conversations were an important opportunity for us to discuss what was happening in the classroom. I prioritized meeting with Shauntá frequently, as I wanted to ensure that her perspective of classroom events was included and that I demonstrated to her in a very real way how I valued her contributions to my inquiry process. I chose to approach these meetings as conversations rather than formal interviews, so I did not develop questions in advance of our meetings. Our Wednesday Reflections were generative in helping Shauntá and me develop new insights into classroom events and her teaching practices and to continuously develop a more trusting relationship.

An important intention of these informal conversations was to provide Shauntá with an opportunity to contribute to the narrative I was crafting, as well as to ensure that her perspectives were included and validated in the study (Glesne, 2016). Although I recognized that there is always a power differential between researcher and participant, these conversations were organic and responsive to recent classroom events, rather than responsive to formal interview questions. Kirsch (2005) stresses that "interviews are a distinct social phenomenon" and as such "are likely to be asymmetrical interactions" (p. 
2165). I attempted to make our Wednesday Reflections as symmetrical as possible, appreciating that "feminist researchers [seek] to create less hierarchical and [more] collaborative research relationships" (Glesne, 2016, p. 13).

\section{Learning Stories as Elicitation Method}

During the third, fourth, fifth, sixth, and eighth Wednesday Reflections, I shared Learning Stories I wrote to Shauntá, and invited her response. Learning Stories are common in Reggio-inspired early childhood classrooms for documenting children's learning over time. They are stories about children "based on [teachers'] observations that reveal new insights into children's perspectives" (Carter \& Curtis, 2013, pp. 9-10). Carter and Curtis describe that many teachers "write them directly to the child, which some people have characterized as akin to a love letter. This brings [the educator's voice] into the story powerfully, always conveying a sense of how competent children are" ( $p$. 254). Learning Stories are written in many Excellence Academy classrooms, and Shauntá

often uses them to communicate children's learning and important moments of discovery. I adapted this teaching practice into a feminist research method by writing about Shauntá's work with children, including the pedagogical moves she made, and by reflecting on my perspective as a feminist researcher. Learning Stories as a research method was an innovative way to elicit data that centered the voice of Shauntá as a research participant. See Figure 3.2 for an example of a Learning Story I wrote and shared with Shauntá. 


\section{Ownership as Empowerment}

Dear Shauntá,

Something I really admire about your teaching practice is the way you consistently empower the children. You do this in a lot of ways, but one way that I see over and over again is how you empower kids by acknowledging their expertise and ownership of the classroom.

One day, $\mathrm{M}$ la was creating with Styrofoam pieces in the building area. As she worked, she glanced at the nearby atelier table, where trays of colorful sand were waiting. She said, "I wanna go play with that sand." As she stood up, she looked at you and asked quietly, "Can I save my work?" You looked to who was working nearby, and asked, ", can you show the Save signs? And tell her what they're for."_stood up, crossed the space, and showed 1 the stack of Save signs tucked on the shelf. He explained, "Put this on your work so no one will mess it up. This is how you do that." He demonstrated placing the sign on the structure, all the while informing that she can always save her work and come back later. As he moved back to his own work,

placed the Save sign in front of her structure and hur over to the sand trays in the atelier.

What this tells me:

You empower the children in your care by acknowledging their expertise of classroom spaces and the joint ownership they all feel for their environment. How easy it would have been for you to show the Save signs yourself, but instead, you seized the opportunity to empower $\mathrm{He}$ happily demonstrated an important practice in your classroom - the ability to save works in progress for later revisiting. being new to the class, learned from a peer an important feature of your classroom community.

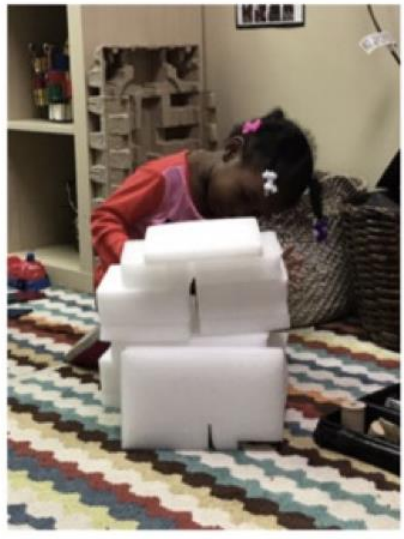

Your voice: What inspired the Save signs? Why are they important in your classroom? What are some other ways you empower the children to take ownership of the classroom?

"Capturing that moment of what they doing. Just capturing that moment. And then asking them, Can you tell me about it? It's their words that tell the story. And they'll tell their parent or tell whoever else comes in, they'll tell them, they'll tell the story of that picture. And I like that, I like that... That's what's really important. That I do value what they do."

Figure 3.2. A Learning Story I wrote for Shauntá during dissertation research.

The process for authoring a Learning Story is individual to each writer, but I came to follow four steps as I wrote Learning Stories for Shauntá. First, I wrote a love letter directly to her. I think of Learning Stories as love letters because they come from a place of love and celebration, rather than evaluation or judgement. Second, I offered my interpretation of the letter, and what it taught me about Shauntá and her teaching practices. Third, I offered a space for response, either verbally or in writing. Finally, I titled the Learning Story in a word or phrase that captured the essence of the story (Angleton \& Whitmore, in press).

Learning Stories were an authentic way for me to communicate my interpretations and understandings of Shauntá's pedagogical moves with her and other individuals and 
groups invested in her work with children. It is important to note that the contents of the Learning Stories were not anomalies, but rather representative moments of consistent practices. As a result, Learning Stories:

- afforded a consistent time and space dedicated to reflective conversations about classroom events and pedagogical practices;

- encouraged me to specifically attend to Shauntá's practices and notice the pedagogical moves she made with children, while working to resist preconceived notions of who she is and recognizing that this data is one interpretation of reality (Pacini-Ketchabaw et al., 2015);

- acknowledged Shauntás expertise regarding her classroom community, her students, her teaching practices, and all of the experiences that intersected as part of being a teacher in a Reggio-inspired space;

- ensured that Shauntá's voice was maintained and her language and speaking style (African American English) were represented with fidelity (Green, 2002; Labov, 1973);

- balanced the power differential between researcher and participant through consistent sharing and conversation about classroom events, which opened spaces for the co-construction of new knowledges and fostered authentic dialogue; and

- involved collaborative effort from Shauntá and me and invited multiple opportunities for Shauntá to tell her stories. Her stories, then, were layered with my interpretations of classroom practices, based on my close attention to the work she engaged in with children. 
Adapting Reggio teaching practices such as Learning Stories to a research method was complementary to feminist methodologies. Learning Stories were also consistent with Reggio practices, as they "allow us to live authentically alongside children, families, and communities" and in my case, teachers (Pacini-Ketchabaw et al., 2015, p. 120). Learning Stories became an integral part of my research process, as I worked to authentically co-construct knowledge with Shauntá: she learned more about her practice as a result of my observations and the resulting Learning Stories, and I learned about her practices and about myself as a feminist researcher.

\section{Sharing Learning Stories: Inviting Participant Voice}

In a typical Wednesday Reflection in which I shared a Learning Story with Shauntá, a causal routine evolved. Each week, I developed one to two questions related to whatever topic we would discuss that day. For example, if the Learning Story pertained to documentation, I began our conversation by asking her open-ended questions about her documentation process. By asking questions before offering my own interpretations, I positioned Shauntá as the expert of her classroom and acknowledged that I valued her perspective. At the conclusion of that part of the conversation, I invited her to read the Learning Story. During the Wednesday Reflection in which I shared the first Learning Story, I offered to read the piece aloud. Shauntá agreed that she would prefer for me to read it; this became our consistent practice as I continued sharing Learning Stories in subsequent weeks.

As I read aloud, I often paused, creating spaces for Shauntá's response - a moment for her to reminisce about a classroom event or describe particular children, or discuss anything else from the Learning Story that was the basis of our conversation. At 
the conclusion, I invited her response by reading whatever prompt I'd written on the Learning Story. I made it clear that she should feel comfortable speaking back directly to the prompt, or to anything else from the Learning Story and our conversation about it. My aim was that the prompt would continue the generative conversation, rather than function as a formal interview question. Shauntá generally took a moment to collect her thoughts and then responded to the Learning Story. These responses were conveyed conversationally and were often punctuated by clarifying questions from me, tangential stories, or other moves typical of casual conversations.

To cull the main themes from Shauntá's response, I transcribed the entire conversation, indicating in bold the parts that were most relevant to the questions or prompts included in the Learning Story. I then wove together those bolded pieces to arrive at the final words that I included. Because I singled out certain parts of the conversation, it was imperative that I share them with Shauntá to ensure that she approved of the ways I represented her responses. I never considered a Learning Story to be complete until I had shared the abridged response with her and received her expressed approval for that representation.

The practice of member checking (Glesne, 2016) is a staple in qualitative research. Glesne (2016) says that member checking provides research participants with the opportunity to offer "their perspectives on [researchers"] interpretations and provide feedback" (p. 212). The Wednesday Reflections served as a more feminist approach to member checking. Our Wednesday conversations moved beyond merely checking in about representation and moving on; rather, each time Shauntá and I talked, we took a 
step toward more conversation. This process was not linear, but cyclical, and aligned with the Reggio tenet of co-constructing knowledge (Edwards, Gandini, \& Forman, 2012).

At the conclusion of the study, I collected the five Learning Stories and, along with photos of Shauntá and myself over the three years of our professional relationship, created a book in the style of a photo essay. This book was gifted to Shaunta at the closure of the study, both to commemorate our time together as a research team, and to offer my gratitude for her consistent support and for welcoming me into her classroom community so graciously.

\section{Data Analysis}

The Excellence Academy is a program for preschools and early childhood centers in low income areas that works to shift teachers and administrators toward an understanding of the early childhood philosophy known as the Reggio approach. In an evaluation study of the Excellence Academy (Whitmore, 2018), the research team conducted monthly observations in nine classrooms in four participating centers to document the changes taking place in classroom environments, teachers' views of children, and pedagogical decisions taking place as a result of teachers' involvement with EA. Using an open coding process (Charmaz, 2014), in which "researchers thought recursively, read and re-read the data, jotted notes about meanings..., and compared one data set to another in search of patterns and answers to the research questions" (Whitmore, 2018, p. 3), we developed a list of descriptive codes from observations, interviews, analyses of the physical environments and photographs. "This process led to a list of codes that described the data, and then to a categorization of the codes" 
(Whitmore, 2018, p. 3) which eventually helped us to develop themes and Learning Stories that reflected the journey of teachers as they participated in the EA.

My initial questions for my subsequent dissertation research revolved around the Reggio tenets of emergent curriculum, classroom environment as "third teacher," and pedagogical documentation. After several weeks of data collection and preliminary analysis, however, the most salient moments in the data were the stories that illustrated pedagogical moves Shauntá made as she enacted the identity of a Reggio teacher and how she enacted those moves across time and events. As is common in qualitative inquiry, the focus of my analysis shifted in response to concurrent data collection and analysis, and I came to center moments that demonstrated the pedagogies Shauntá enacted.

Thematic coding. I began data analysis in Period 1 by thematically coding (Glesne, 2016) the data collected between September 2016 and May 2018, which included nine sets of observation fieldnotes and four interview transcripts. Thematic analysis involves coding data for "further analysis, description, and interpretation" (Glesne, 2016, p. 183). I approached the data set using existing codes from the larger study (Whitmore, 2018), with special attention to the three Reggio tenets that were the focus of my initial research questions: emergent curriculum, classroom environment as "third teacher," and pedagogical documentation.

Open coding. During Period 2, I added to the data set observations, Learning Stories, and responses to Learning Stories collected from January to March 2019. I engaged in an open coding process common to grounded theory (Charmaz, 2014), in which I assigned an open-ended code to each line of observation fieldnotes and 
Wednesday Reflection transcripts. The shift to open coding allowed me to see Shauntá's pedagogical moves, which became the most compelling codes. These codes included in vivo codes (Glesne, 2016), which are words or phrases Shauntá used when she talked about her teaching practices. One such code, "capturing the moment," was a phrase Shauntá frequently used to describe her approach to taking photos of the children for later documenting purposes. Clearly evident were places in the data where I noted Shauntá taking photographs, dictation, or other forms of documentation ("capturing the moment") for the purpose of making children's learning visible.

Analytic memos. The qualitative research practice of memo writing was an integral component of my data analysis process. After each round of expanding fieldnotes, transcribing Wednesday Reflections, and engaging in other research activities, I made a concerted effort to write memos pertaining to the specific piece of data at hand. Regularly engaging in this practice helped me develop new insights, notice patterns, and ask new questions as they arose. Glesne (2016) suggests sitting down to write memos at intentional times and thinking about patterns, connections, and a range of perspectives to explore as data collection continues. Whenever possible, I made the effort to write these memos in my research journal. There were several times, however, when I spoke into an audio recorder to capture my initial thinking, responses, and reflections to various research activities.

Codebook. When I finished coding the full data corpus, I created a list of the open codes and eliminated those with low frequency and those that didn't address my evolving research questions. I created a codebook (Glesne, 2016; see Figure 3.3 for an abbreviated codebook) that helped me identify relationships between the codes and 
develop themes with sub-codes that eventually became the final research themes of the study. For example, play is the basis for many of the children's activities in Shauntás classroom, and as a result, I frequently noted the children's play in my fieldnotes.

However, as I continued to refine my research questions, Shauntá's specific pedagogical moves became the focus of my observations and therefore the focus of my analysis. I set aside several interesting codes for future additional analysis.

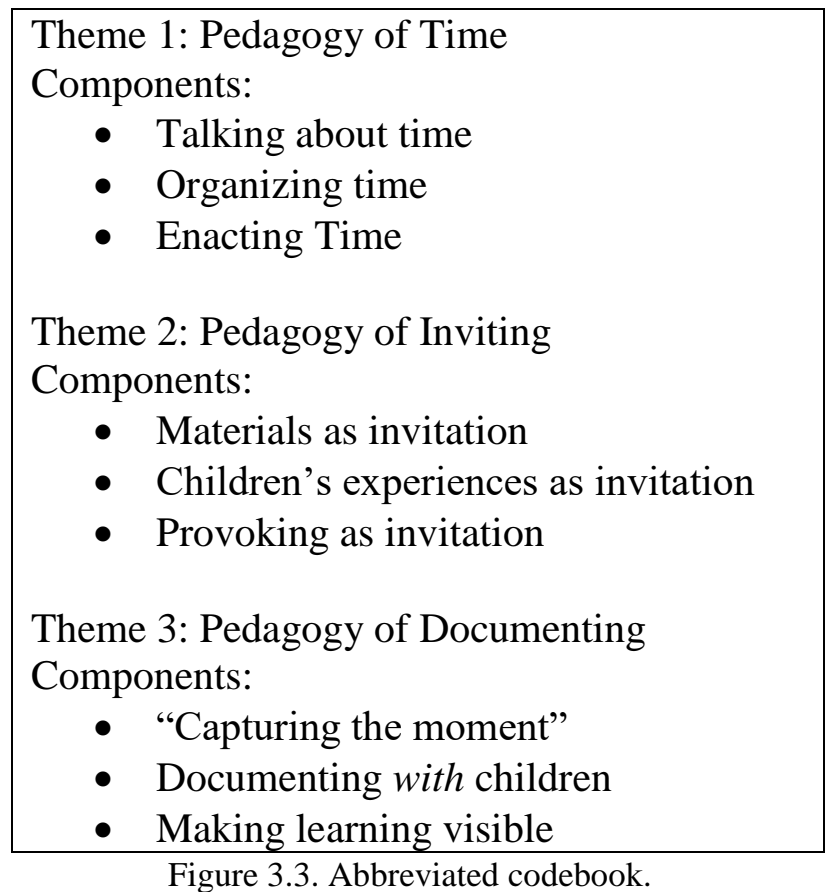

Arriving at the themes - the pedagogies. Saldaña (2015) recommends "continuous review" of the data for "ideas - not just content" (p. 34, emphasis in original). He suggests that thinking thematically helps "frame [the] analyst's lens, filter, and angle with the proper question" (p. 34). As I continued analysis, I amended the codes and their definitions to be more descriptive. This helped me identify relationships and themes among and across the data. I re-coded the full data set with these amended codes (see Figure 3.3). As my research questions continued to evolve, I focused on Shauntá's pedagogical moves, and via the data, I recognized that Shauntá enacted various 
pedagogies. As I attended more closely to the pedagogical moves that Shauntá made, I adopted the term "pedagogies," a designation consistent with Reggio philosophy and practices (see Chapter 1), for three large themes evident in the data: Pedagogy of Time, Pedagogy of Inviting, and Pedagogy of Documentating. Reggio educators conceptualize their work with children through the characterization of pedagogies, and much of the philosophy is built upon this idea, resulting in relational stances enacted as pedagogical work, such as the "pedagogy of well-being," the "pedagogy of relations," the "pedagogy of continuity," and the "pedagogy of listening," among many others (Edwards, Gandini, \& Forman, 2012, p. 11). Time, inviting, and documenting, while all important considerations in Reggio spaces, are not currently discussed in Reggio literature as pedagogies in the way I conceptualize them in the current study. My final pass at the data helped me see these pedagogies across time and events and I realized they served as trustworthy themes in Shauntá's teaching practice.

I identified the way I presented the pedagogies early in my analysis. It was clear to me that the pedagogy of time came first, as it laid the foundation for everything else that happened in Shauntá's classroom. The pedagogy of inviting was the next layer, as time in the classroom was occupied by the execution of inviting, enacted by Shauntá and the children. Finally, Shauntá enacted the pedagogy of documenting in response to invitations; both time and documenting were realized through the pedagogy of time.

\section{Conclusion}

Blaise (2005) says,

There is no single feminist... "method" of doing research. Rather, as a methodology [feminism] draws from a variety of postpositivist paradigms of inquiry, each offering a different approach to generating and legitimating 
knowledge, but where the focus remains on the constructed rather than found worlds of knowledge (p. 46).

I designed this study from my position as a feminist and recognize that my design, methods and writing are constructions of what I observed, heard, and recorded in a Reggio-inspired preschool classroom. Through Wednesday Reflections, and particularly Learning Stories, Shauntá and I constructed new knowledges together. In our conversations about the events in her classroom, we generated and legitimated the multiple interpretations of her pedagogical practices and my stance as a feminist researcher. 


\section{CHAPTER FOUR: \\ A PEDAGOGY OF TIME}

Six low, wooden chairs are lined up in two rows and fill the majority of the

dramatic play area. Several children talk and laugh as they rush to fill up the seats. Kazima, clutching a baby doll, slides her chair back to make space for her legs. The children chat quietly about when the plane will take off. Just outside of the play space, Philip stands near a tall rectangular structure of black and white PVC pipes topped by a child-generated sign: SECURITY. Two children patiently wait in line as he waves a rectangular block covered in black construction paper up one side of Jerica's body and down the other. "Okay, you're safe," says Philip, and ushers Jerica into the airport. Kazima calls, "Ms. Shauntá, you gotta get on the plane!” Shauntá moves to the edge of the dramatic play area and pulls up a chair. She smiles and asks, "Where we going today?" 


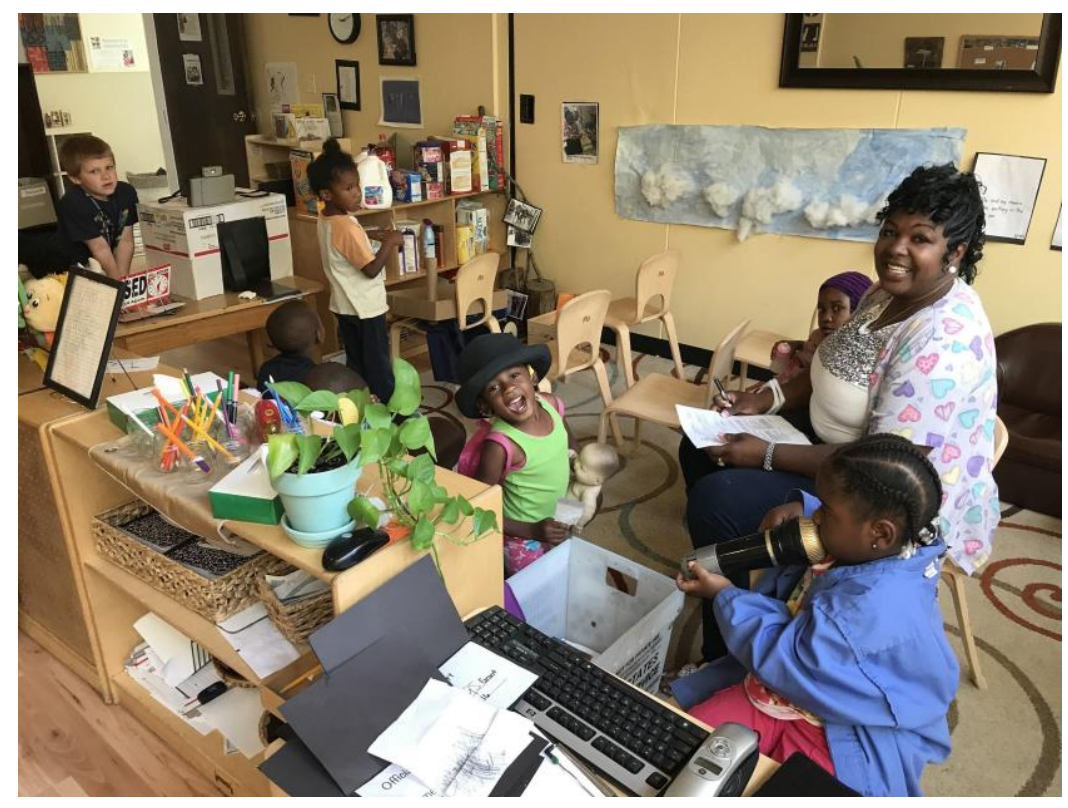

Figure 4.1. Shauntá and the children are ready for takeoff!

The vignette that opens this chapter, and is illustrated in Figure 4.1, was one moment in a 10-week study of airports in Shauntá Miller-Crumes' preschool classroom at Keystone Learning Academy in the summer of 2017. This study, an example of what Reggio educators refer to as emergent curriculum (Stacey, 2018), was born out of the lived experience of one member of the classroom community: 4-year-old Desiree, whose recent trip to the airport to drop off a family member for a flight inspired her journal entries over the next several days. Shauntá, a veteran teacher of 25 years, described emergent curriculum this way: “[Emergent curriculum is] continuous, to me. It's just letting it continue if the children want to talk about it for 10,12 months. They can talk about it." I observed this sense of "letting it continue" firsthand as the airport study evolved over an entire summer in Shauntá's classroom. In mid-June 2017, Desiree composed several journal entries about a trip to the airport with her family. In the first entry she used markers to draw members of her family and an airplane at takeoff. When finished, she handed her journal to Shauntá, who was ready with pen in hand. "Tell me 
about your drawing," Shauntá said. "My family went to get airplane tickets," Desiree began. As Shauntá recorded her words, Desiree pointed to the figures. "That's mama and brother." Shauntá labeled the images and asked questions about the airport visit (see Figure 4.2).
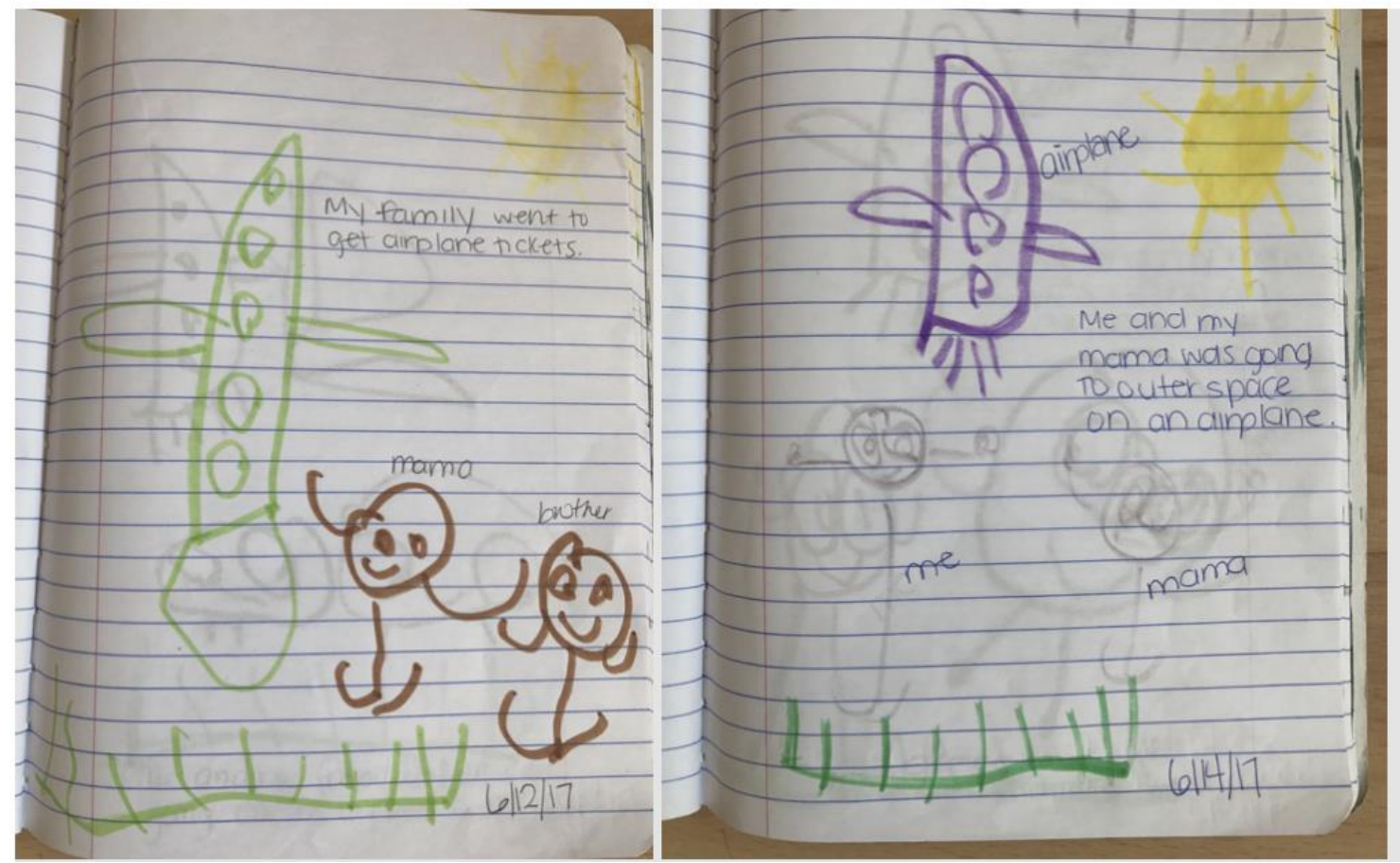

Figure 4.2. Desiree's journal entries about her trip to the airport.

Over the next six school days, Desiree filled her journal with drawings of her family's imagined airplane travels. Though the details varied, one thing was certain: visiting the airport made an impression. Thumbing through the pages of Desiree's journal one day, Shauntá noticed that airplanes filled the pages. She recognized this was significant, and mused, "I wonder what the other children know about airports?" She invited the children to share their knowledge through drawing and writing, then gathered them in a morning meeting to share their experiences with airports and airplanes, memories and stories, and theories about how planes fly. She recorded the manifestations (Meyer \& Whitmore, in press) of children's sharing on a web, which later became the 
center of the airport study documentation board (see Figure 4.3). Desiree's experiences and wonderings about airplanes and airports were taken up by all of the children in the class, and soon her journal entries inspired the emergent study that is the centerpiece of this chapter.

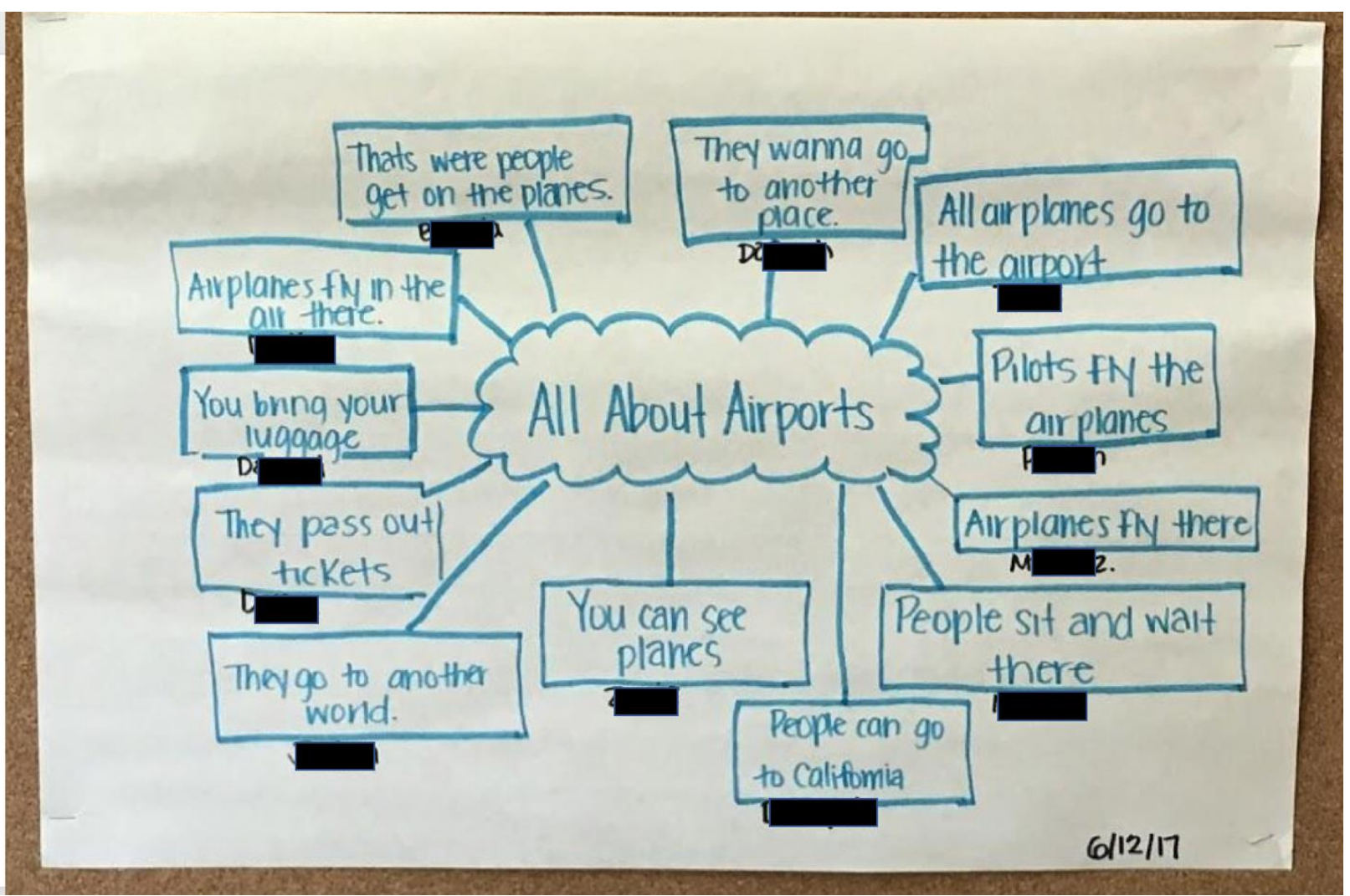

Figure 4.3. Manifestations of children's knowledge of airports.

It was clear during the group conversation that the children had many ideas about airplanes and airports. In response to those ideas, the children dragged classroom chairs into the dramatic play area to serve as airplane seats, and the airport study was born. With their teachers' help, they transformed the space into a bustling airport scene over the next several days. New props and materials were added to the scene each day (see Figure 4.4). First, they created a security checkpoint with PVC pipes, which Philip labeled: Security. Shauntá helped make a baggage scanner and created passports for each child, complete 
with names and photographs. Honor added a microphone to announce flights. Several days later, as enthusiasm for airport play continued to build, families brought in carry-on bags, luggage tags, and used boarding passes. Pretend food appeared on trays at the beginning of each flight's arrival and departure. Kazima suggested they create a strip of sky so they would really feel like they were in the air; the children excitedly painted a long strip of paper in sky blue, complete with fluffy cotton ball clouds.

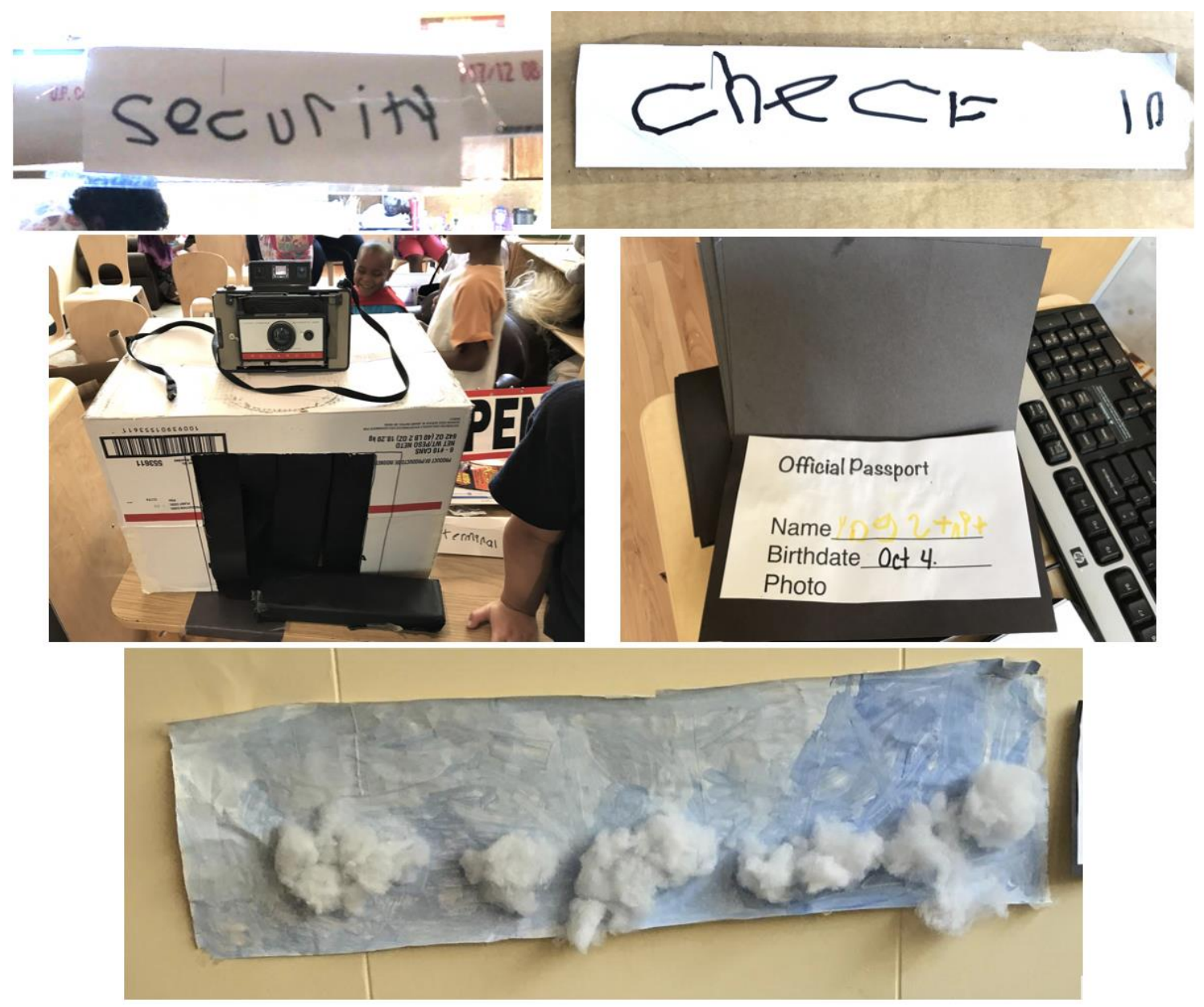

Figure 4.4. Props added to the dramatic play airport.

The stories I tell in this chapter were derived from data generated in Shauntá's classroom, including descriptive fieldnotes, audio and video recordings, semi-formal interviews, and informal conversations. Specifically, I drew from two sets of classroom 
observation fieldnotes from June and July of 2017, as well as from interviews with Shauntá throughout my time as a researcher in her classroom. I also drew upon informal conversations with Shauntá that we came to refer to as Wednesday Reflections, in which we discussed many facets of her teaching practice, including time. In one such Wednesday Reflection I shared a Learning Story I wrote about Shauntá related to the airport study (see Figure 4.5).

\section{A Pedagogy of Time}

The focus of this chapter is the pedagogy of time. The pedagogy of time refers to the intentional pedagogical moves Shauntá made that allowed for children's unencumbered exploration, particularly during inquiry topics that were meaningful to them and were driven by their interests. These pedagogical moves were, in other words, Shauntá's implicit and explicit uses of time to support children's deep engagement in their work or play, as they carried out their personal or collaborative agendas in their own way (Scheinfeld, Haigh, \& Scheinfeld, 2008).

During data analysis, I coded broadly for references to time, as it was a concept that Shauntá and I discussed frequently. As it became apparent that time played an important role in Shauntá's teaching practice, I looked more closely at these moments in the data and recognized three specific elements that made up a pedagogy of time:

- talking about time, which refers to how Shauntá directly talked about time and how it functioned in her classroom;

- organizing time, which refers to the way time was scheduled or structured in Shauntá's classroom, including the flexibility and fluidity of classroom routines and schedules; and 
- enacting time, which refers to the way in which time was lived in the classroom. Collectively, these elements describe the pedagogical moves Shauntá made as she enacted a pedagogy of time. This is a significant difference from most early childhood classrooms, where "the clock plays such a prominent role" (Pacini-Ketchabaw, 2012, p. 155) that it is often difficult for teachers to imagine how they might offer children long stretches of time for work or play.

The story of the airport study demonstrates the ways in which a pedagogy of time was enacted in Shauntá's classroom. Pedagogical work in Reggio Emilia and, to some degree, in Reggio-inspired classrooms such as Shauntá's, is not bound by time. As Dahlberg, Moss, \& Pence (2013) describe, "[T]ime is not organized by the clock, but according to children's own sense of time, their personal rhythms and what they need for the projects on which they are working" (p. 64). Shauntá's commitment to children's long-term exploration of inquiry topics, projects, and play resulted in a pedagogical stance that prioritized the needs of children over strict devotion to a rigid schedule. In the following sections I discuss the three components of the pedagogy of time - talking about time, scheduling time, and enacting time - and illustrate them with stories from the airport study and other moments in Shauntá's classroom. I conclude the chapter with a discussion about how the pedagogy of time in Shauntá's classroom resonates with a reconceptualist view of early childhood education.

\section{Talking About Time}

From the beginning of my relationship with Shauntá, we rarely had a conversation about her classroom in which she didn't reference time: interviews, informal conversations, and casual comments during my classroom observations. I knew that time 
was something Shauntá took very seriously. As I analyzed the data collected in her classroom, I began to see how frequently she used a variation of the phrase "give children time" when she spoke about enacting a Reggio philosophy of teaching. I specifically coded for these moments when she professed this belief and I saw again and again how she brought it up in different settings and in different ways. Talking about time refers to instances when Shauntá spoke about time and its role in her classroom. She recognized that "time is an important driver of pedagogy" (Farquhar, 2016, p. 409). Her phrase "give them that time" or a similar variant indicated her commitment to cultivating long stretches of uninterrupted time in which children could pursue their self-initiated agendas (Scheinfeld, Haigh, \& Scheinfeld, 2008). Importantly, this professed valuing of time translated into her practice as well.

In my first interview with Shauntá in October 2016, we talked about memorable moments from her teaching. As she spoke, she indicated that a big part of her teaching is about providing time for children to blossom. She said, "It's about just giving [kids] that time, not really rushing them. It's not like, 'Okay, time to clean up' at such and such a time, but just giving them that time." Time continued to be an important topic of conversation between the two of us. Nearly a year later in July 2017, I interviewed her for a third time. As she told me a story about reading from the children's journals, she noted, "The airport [study], it came from Desiree going to the airport. She didn't actually get on the plane, but she took her family to the airport. And then that whole week, that's all she drew about." Shauntá recognized that Desiree's writing, sustained over a period of several days, indicated the impact the airport trip had on Desiree's life and imagination. 
Time, again, was playing a crucial role in the way I understood curriculum in her classroom.

During an observation in June 2017, I commented to Shauntá that the children had been playing in the airport for well over thirty minutes. She replied, "Yes! That's what happens when they have time. They engaged. No conflicts. You have to give them time. They have to have the time to get into it." I reflected in my fieldnotes, Time is something that Shauntá values. She brings it up again and again, both in interviews and in informal conversations like this one. The airport study, in particular, was abundant with examples of how Shauntá conceptualized time and her commitment to "giving" it to children. In the opening vignette, as she asked the children, "Where we going today?" she demonstrated her value of children taking the lead; she was confident in their capabilities and worked to follow their lead as she facilitated new experiences and participated in play.

Shauntá's Excellence Academy coach, Lisa Branstetter, noted in a Learning Story about the airport study (see Figure 4.5) that the it was a pivotal moment in Shauntá's thinking about time. Lisa explained that Shauntá had redefined her ideas about time since joining the Excellence Academy and learning Reggio practices: "Her redefinition of time, her engagement with and listening to the children had to be redefined. Slowing down, just being in the moment." Prior to joining the EA, Shauntá's approach to time was far more structured and scheduled around specific activities in which children participated. Like many other early childhood teachers, she taught using predetermined weekly themes and a "letter of the week." In fact, Shauntá was previously well known for her collection of highly organized curriculum materials, stored in tubs labeled with the names of the 
months which she pulled from shelves year after year regardless of the children's interests.

As she grew in her identity as a Reggio teacher, however, Shauntá recognized that "giving children time" was a core principle she could ascribe to. During a Wednesday Reflection in early February 2019, she emphasized, "I have this little saying in my class: 'When you give children time and spaces, you'll see a lot of happy faces."' From our early interviews to conversations nearly two and a half years later, Shauntá maintained her commitment to affording children the time to become engaged in their work and seeing where the unrestrained time took them. "Just giving them that time," she continued. After a pause she finished, "Time to explore and learn." Shauntá's professed value of time was put into practice in new and important ways through, and perhaps because of, the way she enacted time during the airport study. 


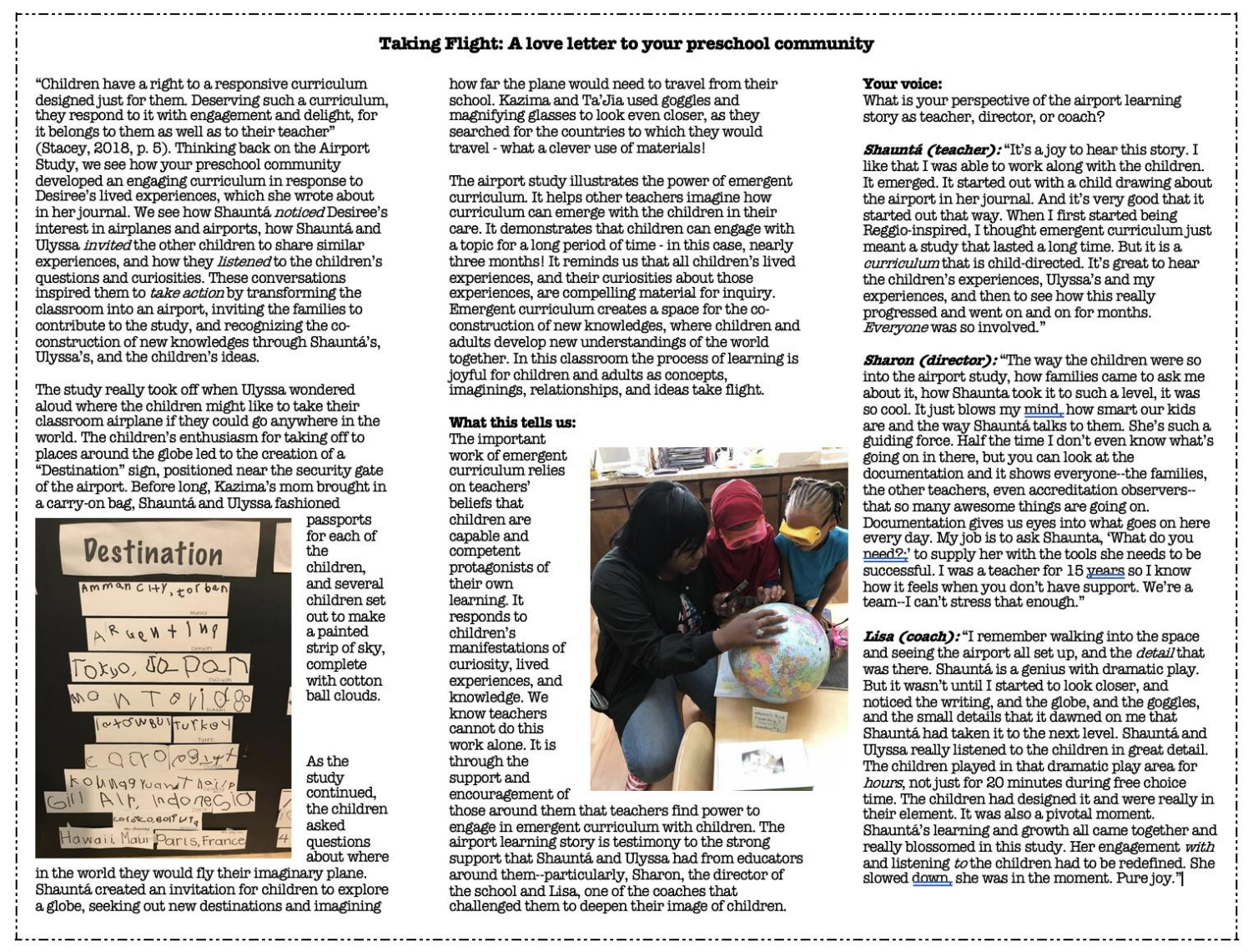

Figure 4.5. A Learning Story about the airport study.

In the airport study, Shauntá "walked the walk" of her stated beliefs about time.

Her commitment to "giving children time" manifested across classroom spaces when she recognized Desiree's devotion to multiple journal entries about airports as significant and as she deliberately slowed down in her approach to curriculum. I discuss these organizational features of Shauntá's classroom in the next section.

\section{Organizing Time}

Organizing time refers to moments when Shauntá altered the daily classroom schedule or routine to support children's pursuits of their agendas. Although there were fixed moments in the daily life of the classroom, such as lunch time, rest time, and special events like water play during the summer, for the most part the classroom 
schedule remained flexible and fluid, as consistent with Reggio philosophy. "In a Reggio Emilia classroom, there are times to eat, sleep, and meet with the group, but there are few unnecessary interruptions in the children's day" (Fraser \& Gestwicki, 2002, p. 13). These "unnecessary interruptions" were few and far between in the daily comings and goings of Shauntá's classroom.

Time, in Shauntá's classroom, was organized rather than strictly scheduled. For example, when the children were deeply engaged in their work, she did not interrupt in order to adhere to a schedule; rather, she invited them to continue working, sometimes relinquishing a classroom routine for continued work time. During one classroom visit, I watched as Shauntá began to gather children for circle time; as she moved around the room, she noticed children deeply engaged in their work. Rather than disrupt that work, she abandoned her initial plan. Instead, she retrieved the classroom iPad and moved around the room, taking photos of children's work in progress. Shauntá prioritized long stretches of time for children's work, which afforded sustained engagement in the various endeavors the children pursued, such a sculpting with clay in the sensory table or exploring flower petals in water.

Shauntá organized time according to her image of children as competent and capable and her belief that children deserve time to accomplish their own goals (Rinaldi, 2006). During a Wednesday Reflection at the end of February 2019, we discussed her image of children as related to the way each day is organized in her classroom. I asked how her classroom might change if she didn't believe that children are capable and competent. She responded, "It'd be different. Things would be more-.." Shaunta paused thoughtfully. "Structured," she concluded. Stacey (2018) says that careful attention to the 
way time is organized is one of the most important ways teachers can respond to children's natural rhythms and adjust existing timeframes accordingly. Shauntá's commitment to "giving children time" allowed her to break free from what Stacey (2018) calls "the stranglehold the clock often has on early childhood programs" (p. 57).

During an observation in April 2018, Shauntá and I watched as Leylo and Fatima, two five-year-olds in Shauntá's class, stooped down and retrieved a glass jar stuffed with brightly colored straws. Carrying the jar to an open space near the back of the classroom, the girls knelt down on the floor and arranged straws on the floor. I took the photos in Figure 4.6 as the girls worked to use the straws to make shapes and letters. Sitting near them on the floor, Shauntá watched as the girls shifted the straws into the letters of their first names. Fatima made an L for Leylo, and Leylo made an F for Fatima. As the girls continued manipulating the straws, Darrin called from a table nearby, "Hey, can you make a D for me?"
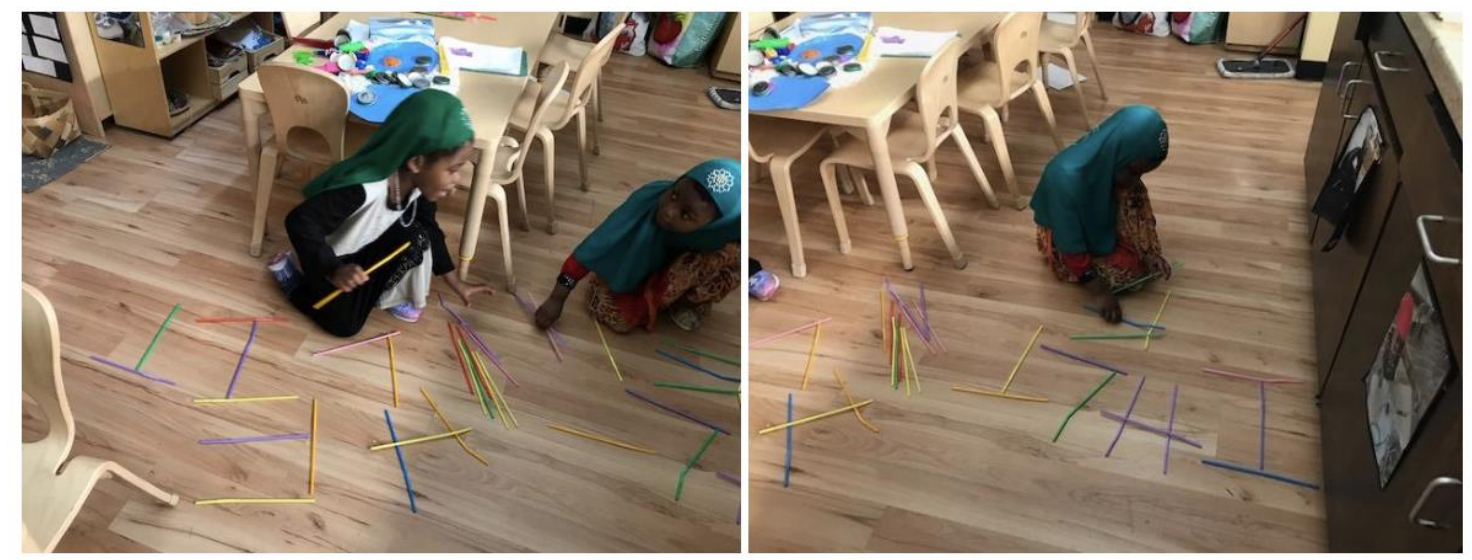

Figure 4.6. Fatima and Leylo create letters with straws.

This story demonstrates how Shauntá organized time in the classroom. The girls continued to work with the straws for most of the morning, slowly, intentionally, and without interference from an adult. They had time to work through their agenda. As 
Shauntá and I continued to watch, she turned to me and said, "You don't need dittos to learn letters. Just give them the materials and they'll learn. They'll get it when they're ready." Her acknowledgement was an important one in support of a pedagogy of time: had Shauntá rushed the girls to clean up or insisted on them completing another activity she'd planned, she might not have come to this realization. But because she respected the time the girls took in the exploration, she identified that they were learning much without adult interference.

An important component in the organization of time is the freedom children had in Shauntá's classroom. She provided opportunities for children to take up their work without feeling rushed and took an active role in the children's explorations and play, facilitating new understandings through careful questions, authentic conversation, and working together to co-construct new knowledges. Her careful considerations of time and the way it functioned opened spaces for deep learning and genuine engagement. In a conversation about the airport study with Lisa Branstetter, I emphasized that so many of the children were involved with the airport study. "Why do you think that was the case?" I asked. "Well, for one thing," she replied, "there wasn't a limit to the number of kids who could play in the dramatic play area." It was the children, then, who decided how and where they spent their time. Lisa added, "The children played in that dramatic play area for hours, not just twenty minutes during free choice time."

Lisa's assertion confirmed the idea that a pedagogy of time was enacted in Shauntá's classroom in thoughtful and intentional ways, which is the focus of the next section. 


\section{Enacting Time}

Shauntá enacted a pedagogy of time in a number of ways throughout the day and across classroom spaces. Perhaps one of the most obvious ways a pedagogy of time was evident in the airport story was the length of the study itself - ten weeks of intense engagement around one topic of interest. In the field of early childhood, the assumption that young children can't attend to projects for long periods of time is taken as fact. In Copple and Bredekamp's (2009) Developmentally Appropriate Practice - a staple in early childhood teacher education classes - the authors state, "As teachers know, preschoolers may have trouble focusing on details, spend only a short time on most tasks, and tend to be more distractible than older children" (p. 132). The airport study disrupted the assumption that children are incapable of focusing on details and spend only a short time on tasks; on the contrary, it was the attention to detail that gave the study momentum, and it was children's ability to engage for an extended period of time that encouraged them to dig so deeply into the subject.

"The meaning of one's time, and experience of time, is structured by the institutional social practices that a person inhabits" (Farquhar, 2016, p. 410). Shauntá's enactment of a pedagogy of time influenced how children navigated their days in the classroom. Because the children knew they had unrestrained time for pursuing their agendas, they capitalized on time and used it to dig deeply into the work at hand, whether that work was exploring new ideas within a months-long inquiry, building structures in the construction area and saving them over several nights for further development, sculpting with clay repeatedly on multiple days, or playing a game continuously with friends from one outside playtime to another. 
Shauntá respected and responded to children's agendas for their learning (Scheinfeld, Haigh, \& Scheinfeld, 2008), including their need to carry over projects for more than one segment of one day, or more than one day, or even multiple weeks. She recognized that pursuing these agendas could not always be accomplished in short bursts of time. As such, she wanted a system in her classroom for helping children preserve their work, even as they operated within the organization of time during the school day. She introduced the children to "save signs" - paper stop signs that read "STOP. Don't Touch. I want to SAVE" (see Figure 4.7). The signs were used by children when they want to continue with a project at another time.

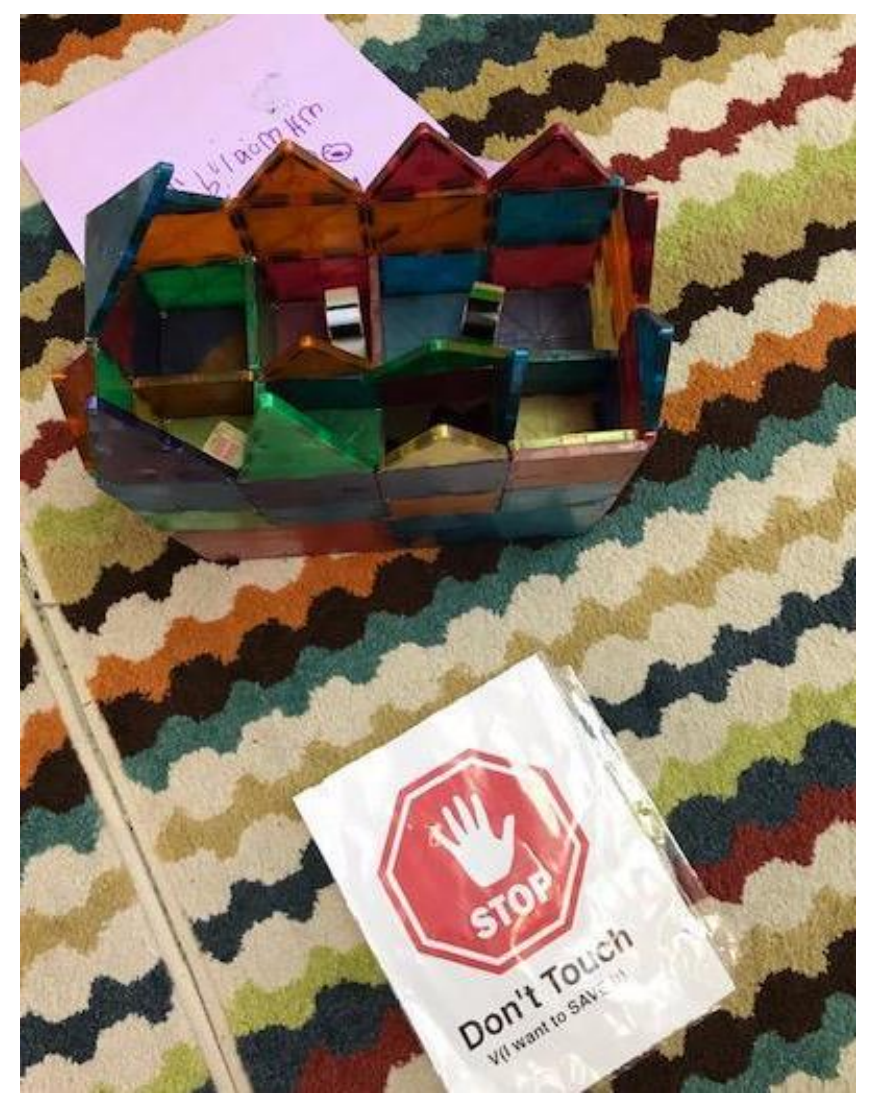

Figure 4.7. Save signs show that kids are still working on a project.

During the airport study, as during other inquiry studies in Shauntá's classroom, the presence of save signs was an important component to enacting a pedagogy of time. 
During a Wednesday Reflection in late February 2019, I asked Shauntá about the signs: How long had she been using them? Where did she get the idea? What role did they play in the kids' work? She described how the signs communicated children's plans and fostered respect from everyone in the school community - other children, teachers, even the custodians at the school. She emphasized how the signs communicate the respect she has for the children and their work. As we continued to talk, I shared my interpretation of her image of children in regard to the save signs. I said, "I think that speaks to your strong image of children, them being able to continue on... That they're able to take time to do stuff." Shauntá agreed. "They're not bound by time, which is another thing I see very consistently from you across the data," I continued, "like observations and interviews, is this idea of --" "Giving them that time," Shauntá interrupted with a nod. Engaging in emergent curriculum such as the airport study requires teachers to take up ideas from children without a prescribed ending in sight. Because emergent curriculum resists standardized outcomes in children's learning, it creates spaces for a democratic classroom in which children act as the protagonists of their own learning (Rinaldi, 2006). A key component of emergent curriculum is time - time for thinking, asking questions, and co-constructing new knowledges as part of a community of learners. Time is necessary for the "incubation and development of big ideas" (Stacey, 2018, p. 57). In order to enact a pedagogy of time, Shauntá had to become cognizant of and deliberate about slowing down. She made the intentional decision to not rush the children. Emergent curriculum in and of itself requires teachers to be comfortable with long stretches of time devoted to children's learning and exploration. The airport study is 
a concrete example of the ways in which time influences the curriculum - and the curriculum influences time.

\section{Possibilities in a Pedagogy of Time}

The predominant early childhood narratives in the city where Shauntá lives and teaches hinge on an acceptance of "school readiness" as a truism perpetuated and cemented by required readiness screeners that deem individual children as ready or not ready for kindergarten. Emphasis on "getting children ready" for kindergarten and fear of outcome data from readiness screening has led many early childhood centers and preschools to focus inappropriately on academics and teacher-directed learning activities, often at the cost of teachers recognizing children's potential. Curtis and Carter (2013) say, "The misguided focus on academics and school readiness keeps many early childhood teachers from seeing children's intrinsically lively minds at work" (p. 59). School readiness often results in rushing children to learn academic skills in isolation and devoid of meaningful connections to their cultural or personal lives. In contrast, a pedagogy of time opens up possibilities for teachers to observe and capitalize on children's strengths and interests - a feat that is not possible when children are rushed from one task to the next in deference to the clock.

Without close inspection, it is easy to assume that enacting a pedagogy of time results in teachers who simply disregard the clock and step aside for children to do as they will. I argue, however, that Shauntá's intentional moves regarding time resulted in what Langford (2010) calls a democratic classroom: In a critique of "child-centered" pedagogy, Langford expresses "disquiet" at the idea that early childhood teachers should remove themselves from classroom spaces in deference to children's desires. Instead, she 
advocates for a democratic approach to early childhood spaces, where adults and children alike are valuable contributors to curricular and other classroom decision-making. Langford's ideas resonate with my analysis of how the pedagogy of time democratizes early childhood teaching to reach the Reggio tenet of children co-constructing knowledge alongside adults (Edwards, Gandini, \& Forman, 2012). By protecting children's time to explore, play, and learn, Shauntá enacted a pedagogy that brought children and adults to the center of the curriculum to learn from one another and contribute to the classroom community. In the airport study, in particular, Shauntá's enactment of a pedagogy of time fostered time for learning together, exploring, and engaging in complex play. When early childhood spaces are democratized through a pedagogy of time, "learning becomes understood as a process whereby both the child and teacher... are actively engaged in events that can be initiated... within an environment that has been set up collaboratively by children and teachers" (Langford, 2010, p. 122).

I return to the possibilities of a pedagogy of time in Chapter Seven. Next, however, I discuss the pedagogy of inviting in Chapter Five, beginning with a vignette about Shauntá's children's fascination with light and shadow. 


\section{CHAPTER FIVE: \\ A PEDAGOGY OF INVITING}

Spring is slipping quickly into summer and a bright shaft of light streams into the cozy library in Shauntá's classroom. Ja'Van, Yaafi, and Corden are quietly reading books when Corden lets out a small gasp. Shauntá has joined them on the rug next to the bookshelf, and the beam of sunlight peeking into the room has found the face of her watch. The light bounces off of the watch and onto the large documentation board above the boys' heads. Corden points as he cries, "Look!" Shauntá, noticing the boys' attention, moves her wrist back and forth, causing the spot of light from her watch to move across the documentation board (Figure 5.1). 


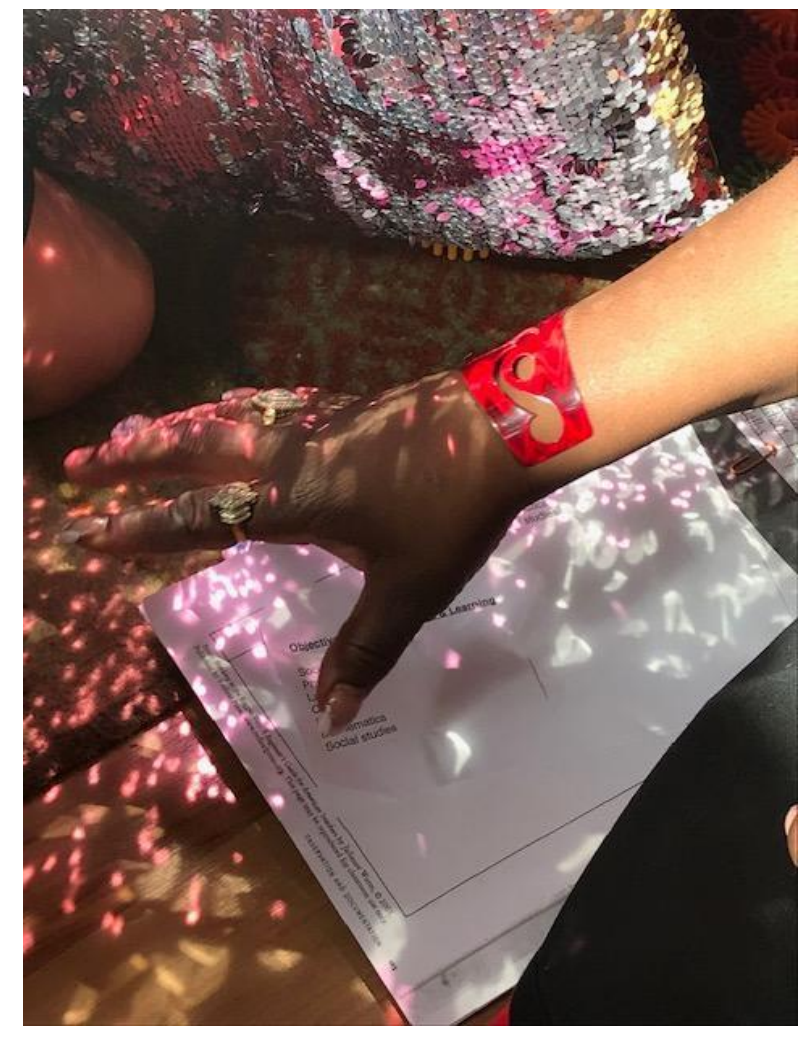

Figure 5.1. Light reflected from Shauntá's watch and sequined pillows dances in the library.

Meanwhile, Yaafi moves sequined pillows around the space, tracing the movement of the light with his eyes. Light from the sequins glimmers across the floor, ceiling, walls, and bookshelf(Figure 5.2). 


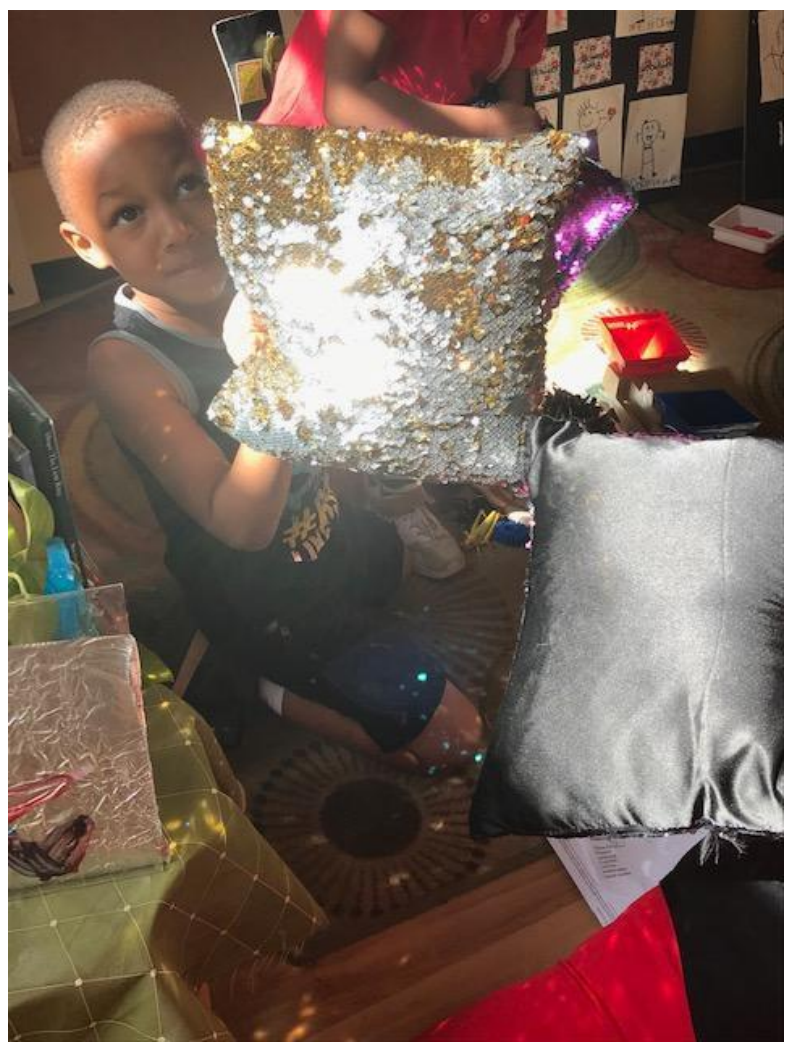

Figure 5.2. Yaafi plays with light and a sequined pillow.

Habiba, responding to the commotion, walks over to the space to investigate. Looking up at the light-speckled ceiling, she exclaims, "That's amazing!" (Figure 5.3). 


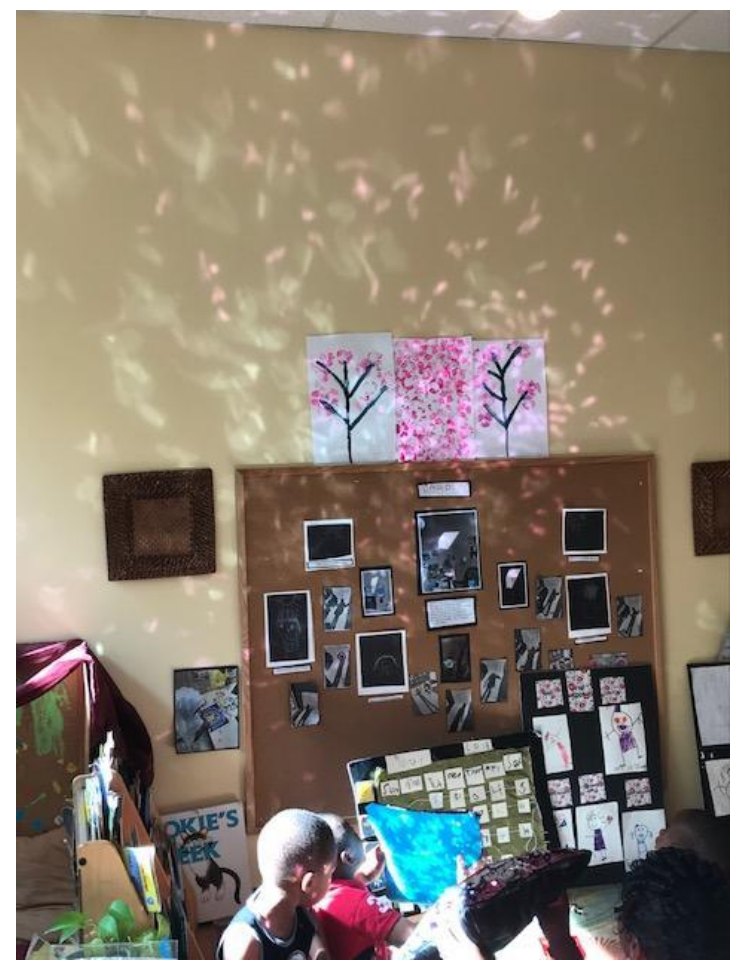

Figure 5.3. "Amazing" reflections of light across the classroom wall.

Shauntá probes the children to make connections between what they are presently seeing and the larger story of their current study. She asks, "How can this happen? What is making all this light?" Jae'van, Habiba, and Yaafi chime, "The sun!" Shauntá probes, "Do you think the pillows would still make light like this if we went to the light room?" There is a bit of hesitation. The light room, a darkened space down the hall from the classroom, is another area where children often go to experiment with different facets of light. "Let's go find out!" Shauntá suggests. The children jump up immediately from their places on the rug and race toward the door, sequined pillows clutched in their fists.

The vignette that opens this chapter and is illustrated by the photos in Figures 5.1, 5.2, and 5.3 was one moment among many in which the children in Shauntá MillerCrumes' preschool classroom at Keystone Learning Academy posed questions and engaged in conversation about light. The emergent study of light and shadows that gave 
life to this moment was inspired by Shauntá's recent engagement and a new diamond ring on her finger. On an earlier occasion, a child noticed the way sunlight streaming into the classroom caught the diamond's hard surface and made interesting and exciting shapes on the wall. In an interview in March 2018, Shauntá caught me up on everything that had happened in her classroom since the last time I'd visited. Noting a new documentation panel on the wall, I asked Shauntá to tell me how the story of how the current study started. She described the following moment from her classroom:

One morning, Ja'Van was sitting at the lunch table and he happened to look up at the wall. He was like, "Ms. Shauntá, there's your diamond ring." We all looked up. He was like, "Take a picture of it." I took a picture and I posted it up. He goes back and revisits it all the time. Well, another child noticed as it moved it gets smaller, so I had to take a picture of that. He went on, he was like, "Well, that's the diamond ring that Mr. Norman (Shauntá's fiancé) gave you."... He asks to see my ring. He put my ring shadow up to the diamond. "Yes," he said, my ring "is a circle. The diamond is a flat square." He was talking about the shapes and then the other children got engaged. They were like, "Wow, the ring, it's getting smaller and smaller." I said, "Tell me why it's getting smaller." They said, "Because the sun is going down. The sun is moving."

As sunny days became more and more frequent with the coming summer, similar moments occurred as Ja' $\mathrm{Van}$ and the rest of the children noticed changes in the shadows and reflections that appeared when sunshine peeked through the skylight.

The stories in this chapter were derived from data collected in Shauntá's classroom that included descriptive fieldnotes of classroom observations, audio and video recordings, photographs, and transcriptions of interviews and Wednesday Reflections weekly, unstructured conversations between Shauntá and me about current events in the classroom. The beam of sunlight on Shauntá's watch - and the many invitations that evolved from it - occurred during one classroom visit in May 2018. 


\section{A Pedagogy of Inviting}

The focus of this chapter is the pedagogy of inviting. During data analysis, I noticed the various ways that Shauntá invited children. Rather than implementing curriculum without regard to children's interests, previous knowledge, or current curiosities, my notes and photographs indicated that Shauntá offered at least three types of invitations, each of which functioned differently. All invitations were intentional, responsive to the children, and designed to help Shauntá better understand the children's thinking, ideas, and interests. The pedagogy of inviting refers to these multiple ways of meaningful inviting, which Shauntá co-constructed with the children in support of their learning. The pedagogy of inviting consists of the following components:

- Materials as invitation, which refers to the physical stuff of invitations, either teacher- or child-generated, that are possible because of the intentional provisioning of materials in the classroom (Stacey, 2018).

- Children's experiences as invitation, which refers to Shauntá explicitly inviting connections to children's lived experiences, both in and out of school (Curtis \& Carter, 2013).

- Provoking as invitation, which refers to interactions in which Shauntá provoked questions, thinking, or further action from children (Fraser \& Gestwicki, 2002).

The story of light on the sequin pillows demonstrates the multiple ways a pedagogy of inviting was enacted in Shauntá's classroom. What began as a spontaneous moment in a typical day - Corden noticing and commenting on the reflection created when sunlight found Shauntá's watch - became a series of invitations that Shauntá 
facilitated in her support of the children's learning. Shauntá provisioned her classroom with open-ended materials that might support the current inquiry and push their thinking, and the three boys connected materials in their environment to their existing and developing understandings of light and shadow. Further, she invited connections to the children's previous experiences in the classroom before provoking new considerations with thoughtful questions and a change in scene, where they might test their theories in new ways.

\section{Materials as Invitation}

Materials as invitation refers to the physical stuff of invitations, either teacher- or child-generated, that are possible because of the intentional provisioning of materials in the classroom. While invitations can be spontaneous and responsive to the moment, they are intentionally enacted, either by the teacher or by children based on the availability of materials and the topic at hand. "An invitation might be an intriguing set of materials that tie [sic] into the children's interest, something new in a learning center, a display that invites hands-on exploration, or perhaps library books on the topic" (Stacey, 2018, p. 107). Invitations can serve as a support and/or challenge as children explore materials.

Shauntá set up invitations throughout the classroom for a variety of purposes. At times, invitations were intended to invite children to different spaces within the classroom; other times, they were meant to expand children's learning about a current inquiry topic. During an early interview when we discussed classroom environment (November 2016), Shauntá told me, "What I'll do is set up invitations in other centers to try to draw their attention or get their interests out [into new areas of the classroom]." She maintained, however, that sometimes children were responsive to her invitations and 
other times, they took the materials in different and unexpected directions. In a Wednesday Reflection in January 2019, she acknowledged, "Sometimes the kids create their own invitations. And that's fine. And you just observe, you know, and listen to them. If they don't go over and do that invitation that's on the table, that's fine. They might not even do the invitation how we think they would do it, which is fine, too. And that's why we document, and take the pictures, so they can see what they did.” This flexibility afforded Shauntá and the children many opportunities to engage with materials in both deliberate and spontaneous ways.

During the light and shadow study in which the opening vignette took place, Shauntá created invitations to learn what the children already knew about the topic and what theories the children had about light and shadows. "Offering an invitation... is one way [to] find out more about the children's thinking" (Stacey, 2018, p. 107). Shauntá invited the children to go outside and study their shadows on a sunny day. Afterward, she suggested they draw their own shadows on black paper with white crayons. When the children explained their drawings, Shauntá made a note and created a documentation panel (see Figure 5.4), so that children could revisit their work, as well as see the work of their classmates. Justice said, "I can see the sun with my shadow." Darrin noted, "You can see your shadow in the sun." Kazima observed, "I can see my shadow when I walk." When creating invitations for children, Stacey (2018) says, "we may not have a clear idea of what will unfold, but if we are willing to take the time to slow down and watch the responses, the children will provide us with a direction" (p. 109). Inviting the children to draw their shadows gave Shauntá a glimpse into what the children knew and provided her with a direction for creating new opportunities for children to explore light and shadows. 
Children's understandings of shadow and light became a jumping off point for additional invitations as the study progressed.

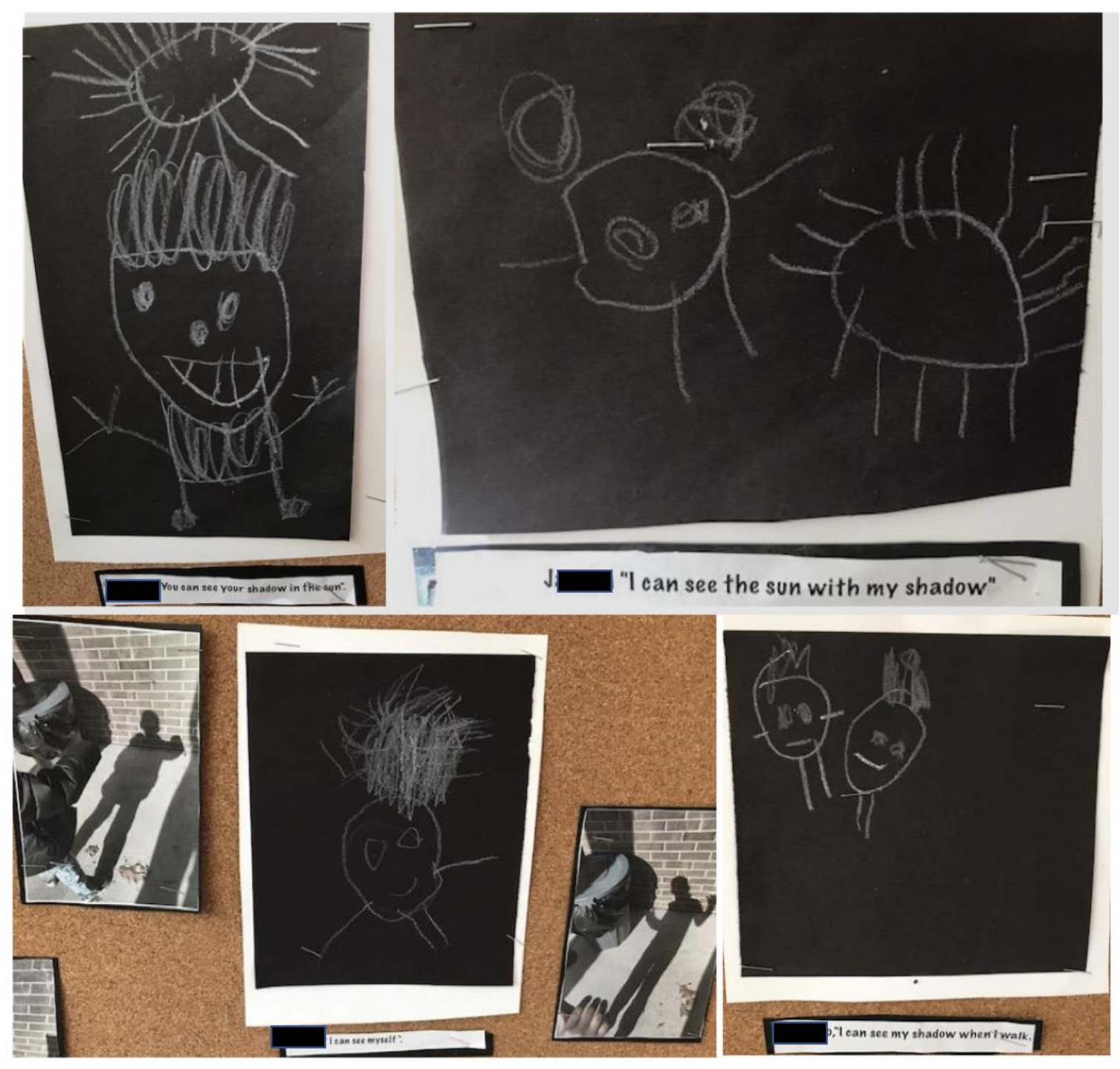

Figure 5.4. A documentation panel about light and shadows.

Shauntá also created invitations to push children's thinking and offer them spaces to test out their ideas in different ways. In an interview in March 2018, she told me a story about another moment in the light and shadow study. Soon after the children noticed the light on her ring, they also noticed traveling squares of light on the wall, 
coming in from the skylights. As they ate lunch, the children offered ideas about the square of light on the wall. Shauntá told me,

I was asking, "What do you think a shadow is?" They told me... what they were thinking the shadow is. Jeremiah said it's got something to do with the sun. They were taking the flashlights today and I brought a plain white sheet in and they were trying to get behind there to see if they could see the sheet. I said, "When it gets really sunny outside, you can put the sheet outside and you all can get behind there and I'll take a picture of your shadow."

This demonstrates how Shauntá created invitations that built on what the children already knew and provided opportunities for developing new hypotheses. Making a plan to provide an invitation with new materials - flashlights and sheets - helped the boys think more deeply about light and shadows, pose new questions, and test their existing theories.

Shauntá was open to spontaneous moments of discovery with materials as much as she was invested in providing materials to further an inquiry. She embraced the spontaneous moment with the sequined pillows, for example, that was possible because of her careful provisioning of materials in the classroom. Although Shauntá didn’t plan for it, she took up the children's noticing of light from the pillows with intention and supported their exploration with gentle probing. Leveraging materials that contributed to conversations about light and shadow provided Shauntá with ideas for taking children's learning to deeper levels. Once the scene was set with these material invitations, Shauntá drew on children's existing experiences, which is the focus of the next section.

\section{Children's Experiences as Invitation}

Listening carefully to children provided Shauntá with "a wealth of ideas for planning a curriculum that [was] meaningful and relevant to the children's lives" (Curtis \& Carter, 2013, p. 227). By carefully observing and listening with intention to children, Shauntá was able to invite them to reflect and make connections to their lives. She was 
carefully attuned to the things that mattered to the children. One day she acknowledged Nigel's burgeoning interest in robots. Another day she asked Dyamonde about the birthday party she knew she attended over the weekend. In yet another example, she remembered that Habiba's grandmother was coming to visit. All of these seemingly small insights into children's lives outside of school were inspiration for Shauntá to create invitations to facilitate new learning.

As was evident in the airport study in Chapter Four, she also paid special attention to the children's journal entries which were bursting with the content that mattered to the children. Shauntá's careful reading of the journals often inspired curriculum studies as she acknowledged the important life events in the journal pages. She told me, "A lot of the studies come from these kids' journals, and what they writing or drawing" (interview, July 2017). Thus, Shauntá leveraged the knowledge children offered to make curricular decisions.

During our first Wednesday Reflection in January 2019, we discussed emergent curriculum studies and how Shauntá intentionally designed curriculum - including invitations - that fostered real-world connections for the children. During our conversation, part of which follows, Shauntá referenced two previous studies from the classroom, one when the children created a pretend doctor's office, and another that investigated grocery stores. She reiterated that making connections to the real world created a classroom that became a community.

Shauntá: $\quad$ You just have to listen to the children. And I told you, I got a lot of my ideas, projects from them, from the children, from their journals. Or from life things. Life living. Like from when [the children were interested that] 
I went to the doctor, that's how the doctor's office got started. And the grocery store. I'd been to Dollar General to bring some things back [and they told me about going to the grocery store, too]. Just bringing things in but really getting your ideas from the children.

Christie: And it seems to me, and maybe this is because you are listening to what they're saying, and you're looking at their journals and stuff, it seems like it's really relevant to their lives.

Shauntá: And that's what you want it to be. Because you want to make that classroom their community. So you want it to be like, "Oh, I went to the doctor." Well, tell us what happened to you when you went to the doctor. And they can discuss that. You went to the grocery store, or have you ever took a trip to the airport. What kinda job do your mom do? Do your mom work? I wonder if she can come in and talk to us about where she work. Here, Shauntá described how she created spaces for children to be in conversation, to make connections to one another's lives, and to acknowledge what they all had in common. Intentionally drawing on children's lived experiences, including inviting families to share about their lives, fostered a sense of community in her classroom.

Shauntá took many opportunities to cultivate a learning community that drew on the knowledges of children and their families. In an interview in March 2018, she described an inquiry study developed in response to her recent engagement to be married. Much like the reflection from the diamond ring inspired questions about shadows and light, the engagement inspired conversations about weddings. Shauntá recounted how the children took on the role of wedding planners as they learned about the many elements of 
weddings. One child, Darrin, was a source of much knowledge, having recently been in a wedding.

“They're planning [my wedding] for me, yes," Shauntá recalled. 'Yes, I'm going to let them plan it. They've already got who's going to do the cake, the DJ, the photographer..."

"It seems like maybe a lot of them have been to weddings before," I mused. "Yes," Shauntá replied.

"Or at least enough to have context," I said.

"Darrin has," Shauntá said. "Darrin has been in a wedding, so he was telling them what he was."

"Yes!" I said with a laugh. "Because he was a ringbearer, right?" "Yes," Shauntá confirmed, then added, "What I'm going to do is have some of my Somali parents give me some pictures of a wedding that they've been in and compare the American wedding to those."

Shauntá acknowledged Darrin's expertise on weddings - and invited information, photos, and stories about weddings in the cultural experiences of all the children. She drew on these lived experiences as a way of valuing everyone's understanding of weddings.

For Ja'Van, one of the children in the opening vignette, Shauntá invited connections to recently acquired understandings to facilitate a new understanding. When Ja'Van pointed out that the light from the sequins reminded him of the "lights at a party," Shauntá confirmed, "It's like the disco ball in the lightroom." She prompted Ja'Van to make a connection to a previous experience, "Remember the disco ball in the lightroom?" 
Drawing on the knowledge Ja'Van possessed, Shauntá facilitated an authentic moment where she prompted Ja'Van to make a connection to something he already knew. As Ja'Van worked to make sense of the current situation, Shauntá framed the lights on the ceiling within his knowledge of the disco ball and previous experiences he had with light sparkling on the walls and ceiling.

This prompting, what Reggio educators call a provocation, opened a space for Ja'Van to connect to a previous experience and take further action, as Shauntá invited the children to move to the light room for additional investigation. Provoking in this way is a form of inviting and is the next component of a pedagogy of inviting.

\section{Provoking as Invitation}

Often, Reggio-inspired teachers use the terms invitation and provocation interchangeably, and it is difficult to distinguish between the two closely related concepts and terms. Fraser and Gestwicki (2002) say that provocations involve "listening closely to the children and devising a means for provoking further thought and action" (p. 11). Because provoking was a form of inviting, Shauntá provoked the children's learning without expectation - she did not require a response or action, but instead intentionally suggested ways children might take their thinking further. Provocation required an interaction: it involved Shauntá interacting with one or more children, attentively nudging them into some sort of action or further thinking. Shauntás intentional provocations for thought and action provided spaces for children to consider her suggestions, yet they had agency to decide for themselves whether or not to take them up.

I first recognized and defined this type of interaction during a visit to Shauntá's classroom in January 2019 when I watched her show Malik a photo on the iPad of a 
structure he created the day before. She asked him to describe his building process and

how he came up with ideas for the different parts. She said, "Maybe you'll want to add to it when we go out [to the construction area] later." This moment was significant to me, as it demonstrated the way she gently invited further action by provoking as a subtle suggestion. It was so significant to my understanding, in fact, that I wrote a Learning Story about it and shared it with Shauntá (see Figure 5.5).

\section{Provoking as Invitation}

Dear Shauntá,

I often notice how your face lights up when you show the kids photos of their own work. Many times, you ask them to share the stories of the photographs in their own words, and you frequently use this as part of the documentation process. During a recent visit to your classroom, you showed a photo you had taken the day before of an intricate structure he'd created in the building area. You asked him to tell you the story of his thinking, what gave him the idea for that particular structure, and asked him to make connections to his own life. As he finished, you said, "Maybe you'll want to add to [your structure]... later." I smiled and looked thoughtful for a moment. I imagined he was considering how he might build upon the work he'd already done.

When you invite children to reflect and make plans for future work, I think of it as "provoking as invitation." You acknowledge the work that is already there and invite the possibilities to come.

What I see:

You value the children's contribution to the documentation process. You understand that their voices powerfully tell the stories of their own experiences. You recognize the potential of inviting reflection and the suggestion of taking action.

Your voice:

What is the most rewarding part of the documentation process for you?

"Just capturing that moment of what they doing. Just capturing that moment. And then asking them, can you tell me about it? [Using] their words. And letting the pictures tell the story. They'll go to their parent or whoever else come in, and they'll tell them, they'll tell the story of that picture. And I like that."

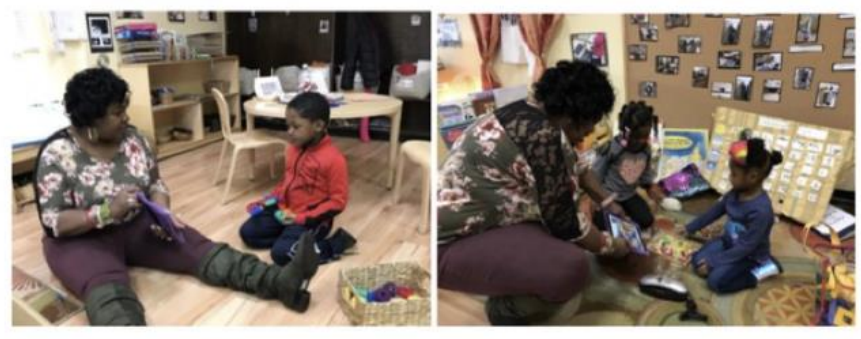

Figure 5.5. A Learning Story I wrote for Shauntá, titled Provoking as Invitation. 
As we discussed the idea of provoking as invitation during a Wednesday Reflection the following week, I said by way of explanation, "It's like you're kind of nudging them, or you ask them a question, and it becomes an invitation to move forward." As we continued to talk, it became clear that we were engaged in what Reggio scholars call the co-construction of new knowledge (Edwards, Gandini, \& Forman, 2012): I was learning about and from Shauntá's pedagogical moves, and she was learning about her own practice through the Learning Story and our discussion of my observations.

"So what I was thinking was that sometimes," I began, after reading the Learning Story aloud, "it's not an invitation that you set up at the table, but your language and the questions that you're asking and the way that you're showing them their work is really inviting them to - "

“ - reflect back on what they already done," Shauntá finished.

"Yeah!” I replied. "And then you kind of provoke them, like..."

“Just asking them open-ended questions," Shauntá said.

Although it was not until this observation that I fully understood how Shauntá was provoking as a form of invitation, looking back at the story of the light and shadow study, it was apparent that this was a consistent practice in her classroom, even if neither of us had the language to describe it at the time.

In an interview in March 2018, Shauntá described a moment early in the light and shadow study about Ja'Van's interest in the light on the wall, and how she sustained the children's interest in it. She said, "Every time he sees it he wants a picture of it. He goes over and compares it to see the light and then they start talking about shadows. I was 
asking, 'What do you think a shadow is?" Asking children for their ideas about shadows was a classic provocation, a question that engaged children's thinking and offered a space to put forth their theories. Shauntá continued, "They told me about it, and I typed it up and put it up on the board, what they were thinking the shadow is. Jeremiah says, 'It's got something to do with the sun."”

The series of invitations in this chapter's opening vignette could easily have ended if Shauntá had not intentionally invited the children to continue exploring in multiple ways. Instead, she used her available resources to provoke them into further thinking, hypothesis posing, and theory testing. Stacey (2018) says, "[E]xperienced facilitators can lend expertise and new experiences that provoke new ways of doing things" (p. 109). In this case, Shauntá accessed the school's lightroom - a long, blackpainted corridor that was home to two light tables, strings of multi-colored lights, and at the very back, a disco ball sparkling enticingly from the ceiling. By inviting the children to move to a new location, Shauntá provided the opportunity for a new experience and to think about their existing understandings in a new way.

Light and shadow explorations are a staple in Reggio classrooms, and educators emphasize the importance of designated spaces for children to interact with light in a variety of ways. Edwards, Gandini, and Forman (2012) say, "This emphasis comes from a deep understanding of how light calls our attention to changes in color, form, and motion, to personal perspective, and to a ubiquitous and integrative source that brings disparate objects into elegant relations" (p. 374). When the children arrived in the lightroom to further test and explore their theories about how the sequined pillows reflected light they quickly held their pillows over the dim glow of the light table along 
the wall (see Figure 5.6). The pillows remained dim, unlike the way they shone in the classroom. Ja'Van headed for the back of the room, as Yaafi declared, "It's too dark." Shauntá paused before asking, "Why’s it too dark?” Habiba jumped up and down.

"Because there's no sun!" she exclaimed. Ja'Van, now standing directly beneath the disco ball, shouted, "It was like this!" bouncing gleefully on the balls of his feet.
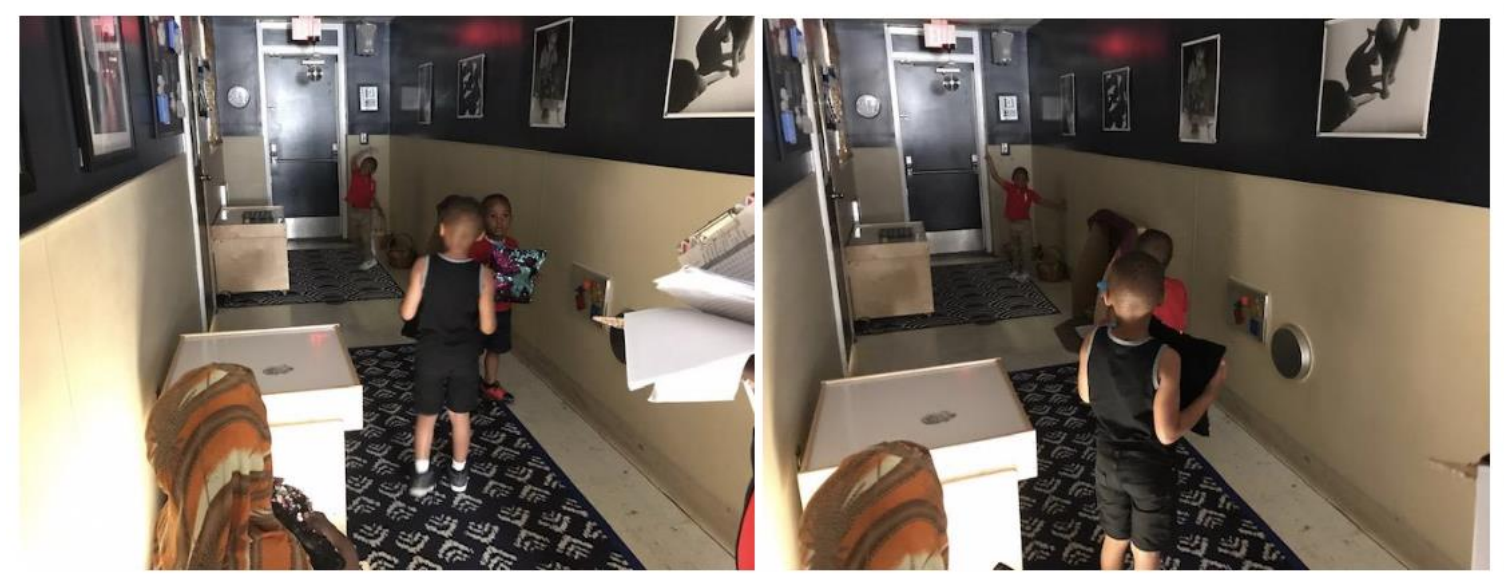

Figure 5.6. Ja'Van makes connections between the sun and a disco ball.

The children confirmed their theories; they experienced that natural and artificial light function in different ways and that in the lightroom, under the artificial light of the disco ball, the sequins behaved differently than in the classroom in the sunshine. This change of scene, at Shauntá's invitation, deepened their learning about light and shadows.

\section{Possibilities are a Pedagogy of Inviting}

A pedagogy of inviting is rife with possibilities for centering the voices of children and their families, acknowledging them as the experts of their own lives. Reconceptualist scholar Cannella (1997) believes children to be "voices of silent knowing." She says the children "with whom we work as they live their real lives in settings that we have not comprehended, ... display strengths and understandings that we have not dreamed of, and ... construct knowledges that would challenge [us]" (p. 3). 
This position is consistent with a pedagogy of inviting: by acknowledging the voices of children as sources of knowledge and sites of meaning-making, and by bringing those voices to the center of curriculum, Shauntá resisted notions that children are anything other than competent and capable protagonists of their own learning (Edwards, Gandini, \& Forman, 2012).

Although Cannella (1997) maintains that "the most critical voices that are silent in our constructions of early childhood education are the children with whom we work" (p. 10), and her claim is valid in many settings, this was not the case in Shauntá's classroom. Rather, she actively worked to listen to children, and one of the ways she accomplished this active listening was through inviting - inviting connections, reflections, and stories of lived experiences, through which she got to know children more intimately. When she invited children to sketch their shadows, she recognized their voices as giving insight to their current understandings. When she invited children and their families to share their family wedding traditions, she centered the experiences of children and gave voice to the moments in their lives that mattered. When she provoked sustained thinking in the light room, she centered children's burgeoning understandings, and built upon them. Inviting in multiple ways allowed her to understand the children's thinking and learning in a variety of ways. She used that information to make compelling, meaningful curricular choices, to best foster genuine learning in the children. By enacting a pedagogy of inviting, Shauntá gave voice to those who are often silenced in early childhood settings: children and their families.

Reconceptualist scholars call for curriculum that is an "experiential, dynamic, relational process" (Pacini-Ketchabaw et al., 2015, p. 36). "Emergent orientations" to 
curriculum "invite prolific input by children" (Heydon, Crocker, \& Zhang, 2014, p.4). With materials, connections to children's lived experiences, and provocations for further action, Shauntá centered children's ideas and input in her invitations to learn. Children contributed to the curriculum and learning community in ways that might otherwise have gone unnoticed in an environment absent of a pedagogy of inviting. Importantly, by inviting in multiple ways, Shauntá resisted the idea of "curriculum development represented by goals, prescribed learning experiences, and evaluation" (Cannella, 1997, pp. 103-104) and instead facilitated a curriculum that was meaningful and relevant to children's lives.

I further explore the possibilities of a pedagogy of inviting in Chapter Seven. In Chapter Six, I discuss the pedagogy of documenting, beginning with a story about Aafiya, a child in Shauntás classroom who shared documentation with me that she had created alongside her teacher. 


\section{CHAPTER SIX: \\ A PEDAGOGY OF DOCUMENTING}

The construction area hums with productivity. Amid the action, Aafiya takes my hand and gently pulls me to a display of robot sketches and a photo of an elaborate block structure, all artfully displayed on a documentation board located just outside the classroom door. As she excitedly tells me the story of her work, her fingers move lightly across the panel. Aafiya's teacher, Shauntá, standing nearby to capture Aafiya's retelling, gently prompts, "Tell Ms. Christie what you was making with those blocks." Aafiya points to the block structure again and says, "Here's the stairs." Pointing to a tall structure in the middle of the photo, Shauntá asks, "And what's this?” Aafiya replies, "It's a telescope. I was looking through it and seeing things bigger." As she continues describing her creations, a small smile lifts the corners of Aafiya's mouth. She nods gently, pride evident in the way she throws back her shoulders as she talks. Soon, Dyamonde approaches and invites Aafiya to come play. She offers me a soft smile before walking away with her friend. 


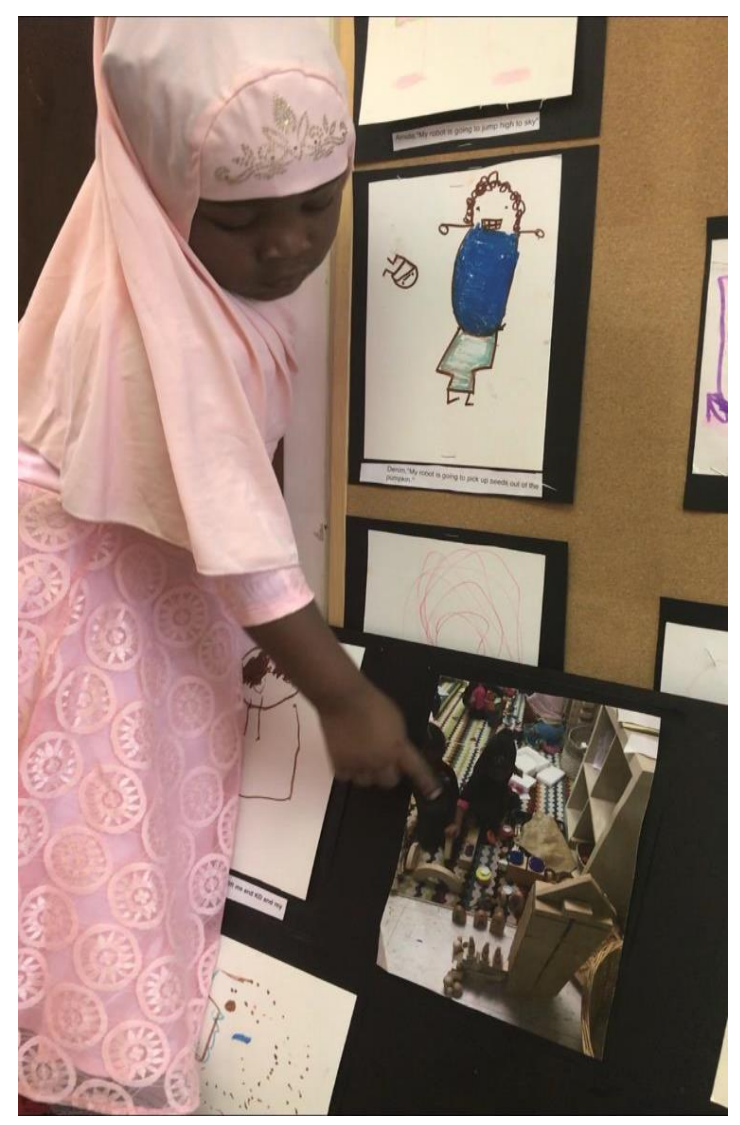

Figure 6.1. Aafiya shares a story about her robot.

The backdrop of Aafiya's story is Shauntá Miller-Crumes' preschool class at Keystone Learning Academy. The documentation displaying Aafiya's artwork and photos of her telescope construction (see Figure 6.1) was part of a long-term study of robots in Shauntá's classroom. While playing with boxes, several of Aafiya's classmates used the available cardboard to create robots. Soon, the excitement about robots extended to most of the children in the class, and most of the spaces in the classroom. It grew into invitations that included the construction of a large, collaboratively created class robot, sketches of imagined robots accompanied by dictation about the special skills each would possess, and photographs of structures that resulted in an entire robot world. Aafiya's robot telescope was one story among many like it, illustrated by documentation panels that emphasized the children's theories, questions, and imaginings. 
The stories in this chapter were derived from data collected in Shauntá's classroom that included descriptive fieldnotes of classroom observations, audio and video recordings, and transcriptions of Wednesday Reflections - weekly, unstructured conversations between Shauntá and me about current events in the classroom.

\section{A Pedagogy of Documenting}

The focus of this chapter is the pedagogy of documenting. I conceptualize the pedagogy of documenting as the act of collecting manifestations (Meyer \& Whitmore, in press) of children's work and play, such as photos, anecdotal notes, and children's work to later tell the story of children's learning and thinking. Meyer and Whitmore define manifestations as "demonstrations of meaning making," including "meaning making processes," "products rendered in meaning making," and "the thought processes in which learners engage as they report to us about their meaning making." They say manifestations are "signifiers of learners' understanding at a point in time and in a specific context” (p. 2). Reggio authors (Stacey, 2018) call this process data collection, likening it to researchers collecting data to answer research questions.

I experienced a dilemma over what to call children's doing. As a classroom teacher, I used the term "work time" to describe the time when children were free to engage with their teachers, classmates, and materials in the ways they best saw fit. This time included playing independently or with friends, reading books, creating art, and engaging in projects related to our current inquiry study. Paley (2005) describes fantasy play as children's work; I use the term "work" here to describe anything children do in pursuit of learning, including fantasy play, creating art, or using any of the hundred languages (Edwards, Gandini, \& Forman, 2012) available to children as they express their thinking 
and learning. The pedagogy of documenting, then, incorporates collecting and thinking about manifestations of children's work, and is comprised of the following components:

- "capturing the moment," which was Shauntá's description of how she gathers artifacts for documentation and the process of documenting;

- documenting with children, which refers to children sharing in the process of creating documentation with Shauntá, or independently; and

- making learning visible, which indicates references in the data to documentation displays and children's and/or teacher's active uses of them.

An important distinction must be made between the Reggio concept of pedagogical documentation (Forman \& Fyfe, 2012) and my term, pedagogy of documenting. Pedagogical documentation, as defined by Reggio educators and scholars, refers to the act of making children's learning visible (Rinaldi, 2006) through photos, dictation, and other artifacts of children's learning and teachers' thinking. "Most simply expressed, pedagogical documentation is a process for making pedagogical (or other) work visible and subject to dialogue, interpretation, contestation, and transformation" (Dahlberg, 2012, p. 225). My term, the pedagogy of documenting, however, refers to the processes involved in what Stacey (2018) calls data collection: observing and listening to children, taking photographs, videos, and notes about children's activities in the classroom, and the act of creating the panels, boards, and Learning Stories that are considered documentation. I was most interested in moments in the data that specifically pointed to Shauntá carrying out the process of capturing children's moments of learning and discovery, rather than the product of pedagogical documentation, such as display panels or polished Learning Stories. 
Although Reggio educators and scholars maintain that pedagogical documentation is itself an agent in the classroom and contributes to children's learning (Rinaldi, 2006) a stance with which I agree - for the purposes of this study I focused specifically on the collection of data that makes pedagogical documentation possible. I paid specific attention to Shauntá's thinking about documenting during those moments when she jotted notes, took photos, or revisited documentation panels within the context of everyday life in her classroom.

The story of Aafiya and her robot demonstrates some of the ways the pedagogy of documenting was enacted in Shauntá's classroom. Although it would be easy to dismiss the act of documenting as merely snapping photos, it is so much more. Stacey (2018) encourages early childhood educators to think about the process of data collection:

As we consider the artifacts, photos, and notes we have collected, we are pushed to make some meaning out of what is happening or what has already happened in the classroom. What is important about this event or project, and why? What do we want to preserve or communicate, and why? How should this documentation be presented and shared? (p. 133).

For Shauntá, the complex and varied purposes of the pedagogy of documenting included capturing the moment, documenting with children, and making learning visible. These are discussed in the following sections and are illuminated by the story of Aafiya and her robot.

\section{Capturing the moment}

Capturing the moment refers to the act of gathering artifacts, such as photos, notes, and children's work, or Shauntá's references to such processes. Shauntá dedicated much energy and attention to the collection of data in her work with children. Using various tools, such as an iPad or iPhone for taking photos and videos, photo editing apps 
such as Pic-Collage, and even mere paper and pen, Shauntá was poised to capture the myriad moments of the children's days. The resulting collections of artifacts were now available for constructing the stories of the children's learning. Stacey (2018) says, "[T]hese materials are the essential and exciting data for assembling documentation" ( $p$. 132).

Shauntá often spoke about the pleasure of "capturing the moment" - of physically taking a photograph or jotting down a clever theory put forth by a child (see Figure 6.2). Since the beginning of my work with Shauntá, I regularly noted her practice of taking notes, photos, and videos while she interacted with children and came to see the consistency in this practice over years of data.

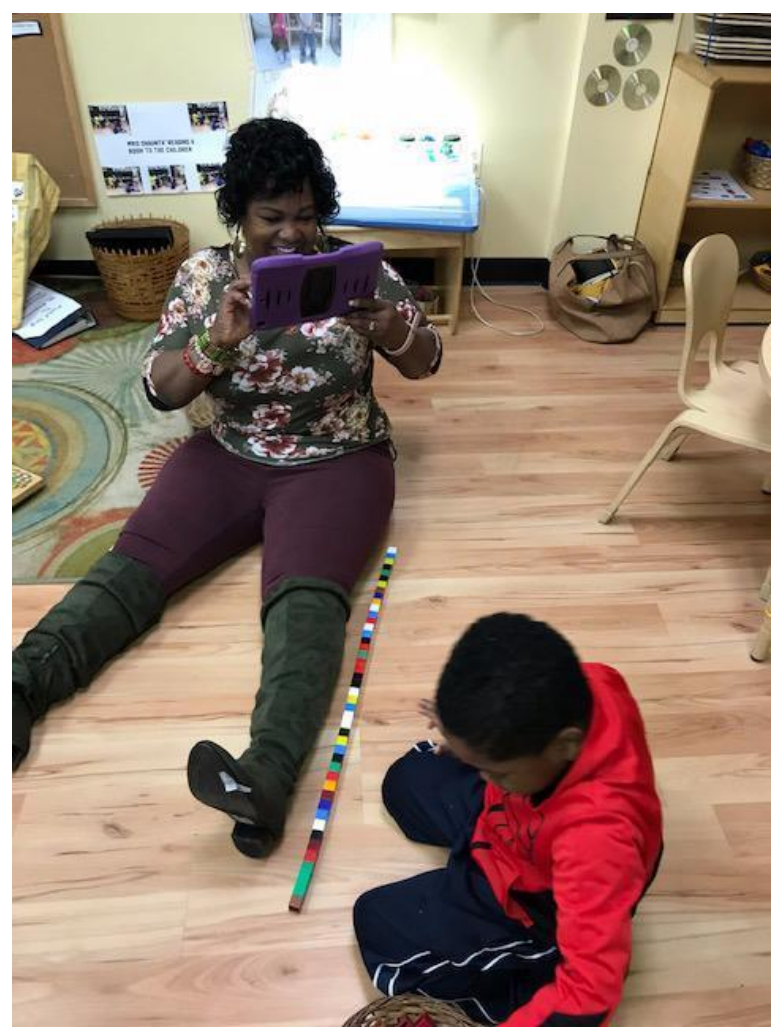

Figure 6.2. Shauntá snaps a photo of Malik at work.

One day I watched as children worked around the room. Shauntá moved among the groups of kids, stopping to ask questions or make comments. At each stop, she took 
photos and notes on the iPad. Two boys arranged sticks on the surface of a small round table. One boy excitedly pointed to a T-shaped creation on the tabletop. He said, "Ms. Shauntá, look at this! What do you think of this airplane? I used short, medium, and long sticks to make it!" Shauntá smiled, snapped a quick photo and said, "You made that!" (November 16, 2016).

On another visit, I observed as Maurice and Darius played with puppets in the gathering area. They ran around the room, moving the puppets up and down in the air and making loud zooming noises. Shauntá moved back and forth between playing alongside the children in dramatic play and taking photos of the boys as they flew around the room (June 19, 2017).

After breakfast one morning, Kazima and Darrin ran to the math table and grabbed a tape measure from a collection of materials there. Kazima laid on the floor, her body stiff and straight. Darrin stretched the tape measure as far as his arms reached. After a brief conversation, Kazima called, “Ms. Shauntá, can you come help us?” Shauntá snapped several photos of the pair before setting the iPad aside and holding the tape measure at Kazima's feet while Darrin stretched it all the way up to her head. After Darrin exclaimed, "Whoa! You're tall!" he and Kazima hurried to the back of the classroom, where they stood on a scale and weighed themselves. Shauntá grabbed the iPad and hurried after them, making notes along the way (April 24, 2018).

In yet another moment, Shauntá watched as several children used large cardboard boxes to create a structure in front of the cubbies. She snapped photos with the iPad and asked the children to tell her about what they were building. As the children negotiated what their structure would ultimately be, Damon and Malik approached with their 
journals. Shauntá sat down with them at the low round table near the box structure and took dictation in their journals as they told the stories of what they had written (January 10, 2019).

Shauntá was also very open about her decision-making process for determining what to document and how best to convey the information. During a Wednesday Reflection in early February 2019, she described her thinking as she "captured the moment." She shared with me that when children do things that catch her attention, especially something unexpected or when they revisit topics over and over again, she knows these moments are rich with possibilities for documenting. Other times, it is the children, rather than Shauntá, who determine when something should be documented. During a visit to her classroom in February 2019, I watched as Malik called out, "Ms. Shauntá, come look at what I built!" Shauntá moved next to Malik and took photos and wrote while he described the structure he created. Shauntá acknowledged Malik's work by asking genuine questions and made note of the pride that Malik had in his work. This pride - and Malik's enthusiasm for sharing his work with Shauntá - demonstrated the kind of environment she fostered. As she returned to the end of the room where I was sitting, she scrolled through the photos she'd just taken and exclaimed, “They all do such interesting things, it's hard to keep track of everything!"

In a Wednesday Reflection on February 13, 2019, Shauntá and I discussed her thoughts on documenting children's work. I wanted to better understand her feelings about documenting, as it can be a challenging and time-consuming endeavor. Part of our conversation appears below: 
Christie: What is the most rewarding part of the documentation process for you?

What's the most meaningful part, or that you like the best about documenting their work?

Shauntá: Just capturing that moment of what they doing. Just capturing that moment and then asking them, "Can you tell me about it?" ... It's in their words. [They] tell the story."

Christie: I think that's really powerful, and it really opens up these spaces where kids know that you value what they do.

Shauntá: That's what's really important. That I do value what they do.

This value was made apparent in the documenting activities Shauntá took up as part of the everyday operations of her classroom. Equally valued was sharing the documenting process with the children, which is the next theme.

\section{Documenting with children}

Documenting with children refers to children sharing in the process of creating documentation with Shauntá or documenting their own work independently. "Words, drawings, materials, colors, and objects can carry the voices and thoughts of children and tell about them... during their absence" (Gandini, 2012b, p. 327). Shauntá's practice of documenting with children told the stories of children's lives, but in collaborative and meaningful formats. It ensured that their interpretations and perspectives were given voice and that their ideas were known.

Shauntá spoke often of the importance of asking children for input as she pulled together artifacts for creating documentation. The most important part of the process, she said, was asking children to tell her what was happening in the photos she'd taken, 
because they were the experts on their own work. "That's why it's important to do the documentations and listen to what they tell me."

That children played an important role in the documenting process was apparent to me in my earliest visits to Shauntá's classroom. During my second observation (December 14, 2016), I watched as two boys sketched battery-powered candles as part of the inquiry study about light. Shauntá took photos and notes as the boys worked, asking clarifying questions and prompting them to consider different ideas within the context of their current study. When they finished, she invited them to create a documentation display (see Figure 6.3). She brought them each a piece of heavy black paper and invited them to glue their work to it. She said, "You make this for your documentation. I'll type up what you said and I'll hang it up." While the kids glued their sketches onto the black paper, Shauntá used the tablet to take photos and make notes about the boys' conversation.

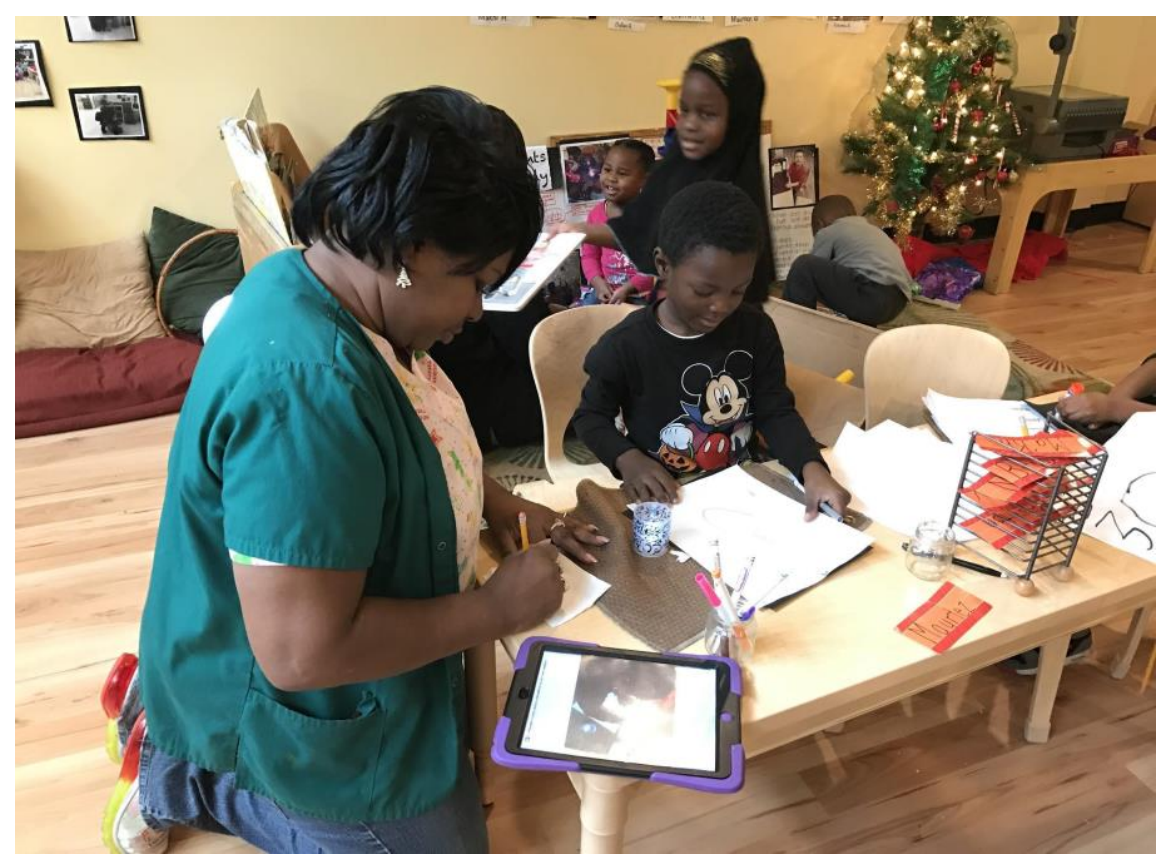

Figure 6.3. Shauntá takes dictation while Jamari creates a documentation display. 
Shauntá was quick to share her belief that the children are the experts of their own work, and as such, their voices should be at the center of any documenting activities. During an interview in July of 2017, Shauntá shared a story from a recent Community of Practice meeting she'd attended (a monthly professional development gathering for teachers in the Excellence Academy [EA]). She told me about how, in this familiar context, she offered advice to other teachers in the Academy who sometimes hesitate to take up the practice of documenting. She said she told other teachers who were struggling to "figure out" documentation,

If you see something that's very interesting that the child is doing, take that picture, document it, ask that child, "What is going on in your picture?" And what that child tell you, that's what you type up, 'cause that child's parent come in and see that documentation, you as the preschool teacher, you don't have to say anything. The picture's gonna speak for itself. And then that child's gonna tell the parent, explain to them what's going on in the picture... They documenting themselves.

By inviting the children into the process of documenting, Shauntá emphasized and relied on their perspectives and interpretations of the moment, acting on Reggio principles about the process. "Documentation not only lends itself to interpretation but is itself interpretation," says Rinaldi (2006). "It is a narrative form... because it offers those who document and those who read the documentation an opportunity for reflection and learning" (pp. 70-71). These "narrative forms" became the stories of the classroom community, co-authored by Shauntá and the children.

It was evident in the story of Aafiya and her robot that documenting with children was a practice that carried much value for Shauntá as a teacher. During a classroom observation, Shauntá shared with me that Aafiya was helping her construct the documentation panel about the robot telescope when her mother arrived to pick her up 
from school. Aafiya asked Shauntá to wait for her return to school to finish the board because she wanted to help with it. When she returned to school the following week, she immediately asked Shauntá if they could finish the piece together. Her mother shared that Aafiya had talked about finishing the panel all weekend. In a Wednesday Reflection in February 2019, Shauntá elaborated on this story, emphasizing that she put the project on hold until Aafiya returned to school. She said, "I had the documentation board and she help me put that together. But she didn't come the next day. So I said [to myself], 'Well, I'm not gonna type anything up until she could tell me what was going on in this story."

I wrote a Learning Story for Shauntá (see Figure 5.3) to convey my appreciation for the way she approached documenting with children. An excerpt from the story, which I shared with Shauntá during a Wednesday Reflection, read: You value the children's contribution to the documentation process. You understand that their voices powerfully tell the stories of their own experiences. These stories became accessible through the documenting process, and were made visible for children's and teachers' use, which is the next component in the pedagogy of documenting.

\section{Making learning visible}

Making learning visible refers to moments in the data when children and/or teachers actively revisited, reread, or engaged with documentation displays in some other way. Reggio scholars use the term "making learning visible" to describe the entire process of pedagogical documentation (Rinaldi, 2006), from initially collecting artifacts to crafting narratives and documentation panels that tell the story of children's learning. I use the term to identify moments when children and teachers made use of documentation displays to revisit, reflect, and formulate new ideas. 
When teachers take up the practice of making children's learning visible, they create spaces for children's deep considerations of their own work. "Children's work is documented, explained, made accessible, and shared. Their interests, as well as the learning that took place through the exploration and investigation of those interests, are made explicit in an engaging and meaningful format" (Stacey, 2018, p. 132). These explicit displays are an essential part of children's active use of documentation as a springboard for new thinking and knowledge construction. Shauntá emphasized in a November 2016 interview the important role documentation boards played in her classroom for conveying what the children were learning. She said, "[B]ecause the kids revisit, when their parents come in they go back and tell their parents what we're talking about. And then I write down what they tell me to write down because that's their documentation." Stacey (2018) recognizes that this process communicates how children and teachers spend their time together. She says documentation is "...a very useful piece of work being shared with others, validating the work of both teachers and children" ( $\mathrm{p}$. 133).

During my first visit to her classroom (November 16, 2016), I watched as Shauntá brought a documentation board to the carpet where the children gathered for circle time. She handed the panel - photos and words arranged on a piece of heavy black poster board - to Philip, who was the circle time leader of the day. The panel told the story of a class trip to an apple stand the month before. When the children returned to their classroom, they decided to build their own apple stand and study apples. Philip facilitated revisiting a piece of documentation about an experiment the children conducted to see what would happen to apples when they were exposed to air. The children discussed how the apples 
changed after they were cut. Shauntá asked, "Why did the apples change color?" The children yelled, "Oxidation!" echoing the information on the panel.

On another day (February 17, 2017), I watched as three children sat on the kidsized couch in the dramatic play area. Corden said, "This is our car. We going to get my cousin at Chuck E. Cheese." Shauntá snapped a photo of the three with the iPad and the children immediately asked to see it. She flipped the tablet around so the children could see. Corden scrolled through several photos Shauntá recently took. Shauntá said, "Look, this is from our sink and float activity yesterday." They continued scrolling through the photos for several minutes, talking about different items that sank or floated. Shauntá asked questions about the activity, and the children described the different objects, pointing to the photos as they spoke.

During another visit (February 18, 2019), I listened as Habiba pointed to her work on the documentation board located in the construction area, just outside of the classroom door. The board was a record of the children's recent study of robots. Habiba described the robot she made and said, "My robot is gonna pick up a trash can." Stepping away from the board, Habiba moved her arms and legs in a jerky motion, demonstrating how her robot looks when picking up the trash can. She then returned to the board, pointed to her robot, and told me, "Her name is Kitty Girl."

"Documentation... offers children a valuable opportunity for revisiting, reflection, interpretation, and self-organization of knowledge" (Rinaldi, 2006, p. 58). Shauntá, too, recognized the valuable opportunity of noticing when children are revisiting and reflecting on documentation displays. During a Wednesday Reflection in February 2019, she shared a story of documentation in action. When Jennifer Pruitt, Shauntá's current 
EA coach, visited the classroom, she commented on a photo of two children revisiting a documentation board. Shauntá told her, "Yeah, I caught them going back and doing that, so I had to capture that." In our conversation, she continued, "Because they are, they're going back and revisiting and telling each other what each other was making [in the photo]."

For Aafiya, revisiting and sharing her work with me (as I described in the opening vignette) made visible her thinking and the actions she took to convey meaning. The sketch she drew (see Figure 6.4) of herself holding the block telescope she created demonstrated her imagination, her creativity, and her knowledge about telescopes. The documentation itself became a means for Aafiya to express the story of her work with the idea of robots; it established the ways she conceived of her ideas and then carried them through, a process that Rinaldi (2006) believes "not only [testifies] to the children's learning paths and processes, but can actually make them possible because they are visible" (p. 100). 


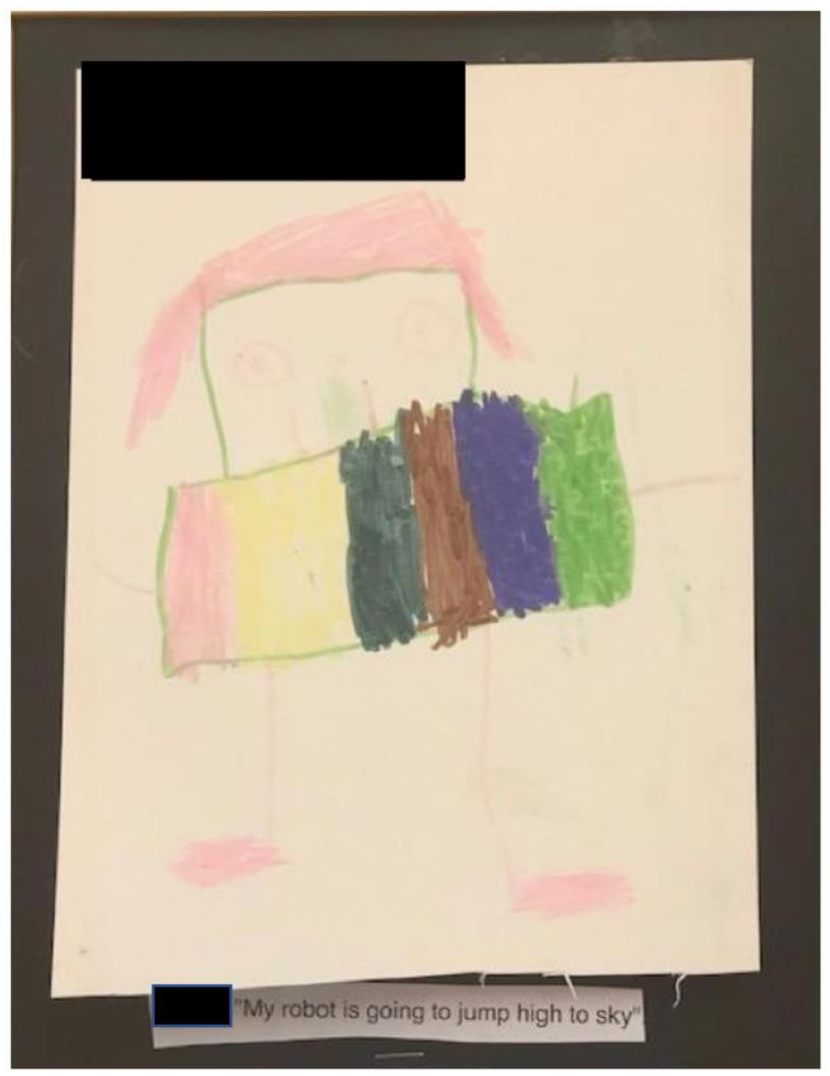

Figure 6.4. Aafiya's robot sketch.

Sharon Hemingway, the director at Keystone Learning Academy, summed up the value of documenting and what it affords the teachers, children, families, and the broader school community. She said, "Documentation gives us eyes into what goes on [in Shauntá's classroom] every day." It is the practice of documenting - recognizing the value in pedagogical documentation - that encouraged Shauntá to engage in collecting data and making sense of it with children, thereby "giving eyes" into the thinking and learning of all members of the classroom community.

\section{Possibilities in a Pedagogy of Documenting}

Standardized early childhood assessments such as checklists and developmental screenings are all too common in early childhood settings. They are often mandated by state departments of education who license programs and they are frequently requested 
by funding agencies who want educators to "prove success" as a result of new interventions and initiatives. As a result, teacher education and professional development providers are often compelled to provide training in using and interpreting such instruments. These mandates perpetuate status quo orientations to learning that built on deficit understandings about children, childhood, and learning (Cannella, 1997).

Standardized assessments and developmental screeners fail to demonstrate what children know. They focus on what children don't know - or rather, on perceptions of what they don't know as defined by narrow ideals of development and learning. Aafiya's knowledge of telescopes or Malik's aptitude for building intricate structures could never be documented on a standardized assessment. Common early childhood assessment practices are so narrow and oriented around identifying deficits that they foreclose teachers' access to the possibilities children bring with them into their school experiences. Curtis \& Carter (2013) stress that standardized assessment is foundational to most early learning initiatives, at the detriment of children and teachers. "These programs emphasize assessment, standards, and curriculum models that focus on teaching children to meet identified outcomes. They do not enhance or maximize the eager dispositions and huge capacity children already bring to the learning process" (p. 59).

Conversely, a pedagogy of documenting relies not on checking off boxes or measuring children's abilities by some ideal standard but as Shauntá's practice illustrates, by providing a more complete and contextualized picture of children's competencies and capabilities (Rinaldi, 2006). Documenting in multiple ways - by capturing the moment, alongside children, and making learning visible - afforded opportunities for Shauntá to see children as whole, rather than mere subjects of checklists or screenings. Through a 
pedagogy of documenting, Shauntá honored children's potential and made that potential visible to them, their families, the school, and the broader community.

In this chapter, I described the pedagogy of documenting and the possibilities it afforded Shauntá and the children in her classroom. In Chapter Seven, I summarize the study and offer a discussion of my findings through a reconceptualist lens. 


\section{CHAPTER SEVEN: \\ PEDAGOGIES OF POSSIBILITY}

This study was designed in three overlapping periods of data collection and analysis, in which I carried out a feminist ethnographic study in Shauntá Miller-Crumes' Reggio-inspired preschool classroom at Keystone Learning Academy. The study encompassed seventeen classroom observations, eleven interviews and Wednesday Reflections, and the writing and sharing of five Learning Stories based on ethnographic descriptions and analysis. I fulfilled the intention of a feminist study by centering and preserving Shauntá's voice, acknowledging her as the expert of her classroom, and working to balance the power differential as we co-constructed new knowledges together. Taking up a feminist stance allowed me to carry my feminist beliefs into my work with Shauntá and the children in her class (Ahmed, 2017).

During a concurrent period of intensive fieldworking and data analysis, I came to see the ways Shauntá embodied the identity of a Reggio teacher through the pedagogies she enacted, particularly during interactions with the children in her class. During classroom observations, in particular, I saw the explicit and subtle ways Shauntá interacted with children, positioning them as competent and capable agents in their own learning. In taking up the Reggio approach, Shauntá enacted pedagogical moves reflective of the philosophy. To better understand the pedagogical moves she made, I 
analyzed the data with special attention to her interactions with children, as these were frequently the moments when those moves became evident.

I met Shauntá in the fall of 2016 when I was assigned as a researcher in her classroom on the Documenting Stories on the Journey to Excellence project (Whitmore, 2018) and began conducting observations in her classroom shortly thereafter. Over the next two years, as a researcher collecting stories of teachers in the Excellence Academy in her classroom, I developed a connection with Shauntá: her work with children, as situated within the Reggio philosophy, was evolving in ways that were familiar to me from my own days as a classroom teacher. As my involvement with the Excellence Academy continued and deepened, my understanding of the Reggio approach also deepened as I engaged in research activities in Shauntá's classroom and others, and as I attended Excellence Academy Communities of Practice.

After spending about two years in her classroom, I knew I wanted to continue our professional relationship, and I felt certain that we could learn about and from one another as I pursued my own research questions. My familiarity with Shauntá and her classroom was the first of many reasons I wanted to conduct my dissertation study with her at Keystone. I also chose this site because I believed in Reggio as an approach to early childhood education that could offer a counternarrative to the deficit-based stereotypes that people often believe about children in spaces like Keystone: that they are not able or deserving of a holistic, progressive approach to learning. Finally, I was affected by Shauntá's history of creating meaningful curriculum with the children. I knew her teaching was centered in diverse and varied studies that drew from the children's lives. As I engaged in my work in her classroom, the questions that became the most 
compelling to me were those that evolved in response to the pedagogical moves she made in her teaching practice. These pedagogical moves became the focus of my study, resulting in the following questions that guided my inquiry:

1. What pedagogies are evident in Shauntá's classroom as she enacts the identity of a Reggio teacher?

2. How are these pedagogies enacted across time and events as Shauntá interacts with children?

3. Why are these pedagogies important in the current political climate? These questions evolved as I noticed the teaching moves Shauntá made in explicit and subtle ways. I was compelled to think about how her practices may have changed - or not - since my first observations in her classroom more than two years earlier. I also wondered how these pedagogical moves were connected to Shauntá's image of children, and how Shauntá navigated the tensions that resulted from the disconnect between her embodied teaching practices and the local, state, and national conversation about early childhood education.

\section{Pedagogies of Possibility}

The philosophical tenets of the Reggio approach - and by extension, the pedagogies enacted within it - inform and are informed by one another. By its very nature, the Reggio philosophy can be likened to a tapestry: each thread is reliant on those around it, and often the threads are difficult to separate; the whole is more than the sum of its parts. Likewise, the three pedagogies that emerged to become the focus of this study - time, inviting, and documenting - could not be separated. They reflected Shauntá's enactment of the Reggio philosophy as understood in her specific classroom 
context. The pedagogy of time refers to the intentional pedagogical moves Shauntá made that allowed for children's unencumbered exploration of an inquiry topic, particularly those topics that were meaningful to them and were driven by their interests The pedagogy of inviting refers to the multiple ways of meaningful inviting, which Shauntá co-constructed with the children in support of their learning. The pedagogy of documenting incorporates collecting and thinking about manifestations of children's work. These pedagogies are consistent with Reggio beliefs and practices and it was evident that taking up these pedagogies was reflective of Shauntá's identity as a Reggioinspired educator, even if she did not name them as such.

The pedagogies Shauntá enacted in her work with children were connected in very similar ways and were often difficult to tease out. The pedagogy of time, for example, laid a foundation for the countless ways Shauntá invited and engaged with children; she took up a variety of documenting practices in response to the numerous forms of inviting she enacted. The pedagogies afforded children time to engage and explore, centered their interests and lived experiences in invitations, and made those experiences visible in documentation. They became opportunities for imagining what was possible for the children - and for Shauntá as their teacher.

The most salient findings of the study came through focusing on the interactions between Shauntá and the children. Equally important were the stories Shauntá told about her interactions with children, in both formal interviews and in our Wednesday Reflections. Focusing on the interactions called my attention to the ways Shauntá enacted the identity of a Reggio teacher. Lewin-Benham (2006) highlights that Reggio teachers' work "reflects [their] fundamental belief that children are rich, strong, and powerful" and 
that this belief "drives how they teach and what they teach" (p. 12, emphasis in original). For Shauntá, enacting the pedagogies of time, inviting, and documenting was born out of the interactions with the children she understood to be rich, strong, and powerful.

Enacting the pedagogies of time, inviting, and documenting opened up possibilities for Shauntá to get to know children intimately, to better understand their lived experiences, and to legitimize those experiences through documentation. Shauntá's enactment of the pedagogies positioned children in an asset perspective, full of potential and possibility. Asset-based pedagogies position children as having unique competencies, born out of their cultural experiences (López, 2017). They acknowledge and validate the cultural assets and lived experiences of children, particularly children of color or others who are traditionally marginalized (Morrison, 2017).

Shauntá's strong, asset-based image of children informed every pedagogical move she made in her classroom. Without a strong image of children, the pedagogies of time, inviting, and documenting could not exist - or rather, they would be unnecessary. Shauntá's image of the child was foundational to the enactment of every curricular and pedagogical move in her classroom. Without this image, she wouldn't enact pedagogies that empower and validate children's lives. And she wouldn't need to. Shauntá hadn't always taught in this way, and she recognized that taking up the Reggio approach had changed her teaching for the better. She emphasized, "My teaching tactics have really changed since I've been in this (the Excellence Academy), in the Reggio inspired. And it's a journey. It's been a journey, a good journey. I can reflect back and think, oh I remember I used to do it this way. Now I'm doing it this way and the kids are progressing and growing." Possibilities for children widen and deepen when they are afforded time to 
play, explore, and ask questions; when they are invited into learning experiences that are activated by their interests and lived experiences; and when their learning is made visible through documentation that validates and values their contributions to the learning communities of which they are an integral part.

\section{Disrupting Deficits: A Counternarrative}

This study was grounded in the reconceptualist perspective on early childhood education (e.g., Cannella, 1997). I wanted to understand Shauntá's classroom, her pedagogical moves, and her interactions through a reconceptualist lens. Moss (2019) calls reconceptualist scholarship an alternative story to those so common in early childhood education, noting that stories or narratives are the way humans make meaning of the world and their place in it. He says, "Stories... construct or weave reality for us, and, as such have consequences..." (p. 13). For Shauntá, the early childhood education narratives in her city - and throughout North America - are steeped in stereotypes and deficit perspectives. Dominant narratives "exclude, or attempt to, other ways of understanding and interpreting the world, of weaving reality, marginalizing, or drowning out other stories" (Moss, 2019, p. 14). In the case of this study, those dominant narratives applied to children of color, children who are economically disadvantaged, their families, their "zip codes," their schools, and their teachers. They would have us believe that the children of Keystone and schools like it lack potential. This study of Shauntá's classroom, however, disrupts those narratives by contesting negative assumptions about the children in Shauntá's care and suggesting a deeper understanding of the potential of all children. 
Although the dominant narratives would have us believe otherwise, Moss (2019) reminds us that "early childhood education can be viewed from many different perspectives. There is no one objectively true viewpoint, rather there are many ways of thinking, talking about, and doing early childhood... education" (p. 14). The stories from Shauntá's classroom, realized through the pedagogies she enacted, indicate the potential of early childhood education for all children, and the possibilities the Reggio approach afford them - and their teachers.

The philosophy of Reggio Emilia is not a "transferable program or universal blueprint... for early childhood education" but rather it is a "local cultural project that has emerged from a very particular time and place" (Moss, 2019, p. 18, emphasis in original). Shauntá frequently acknowledged this idea and emphasized that taking up the Reggio approach was meant to inspire her and her colleagues in the Excellence Academy (EA). She asserted the importance of seeking inspiration without forgetting the significance of her particular cultural context. She often said, "We Reggio-inspired and that's the best we can be. These children are not Italian!" While said mostly in jest, Shauntá acknowledged the importance of situating the Reggio approach in this specific local context: Keystone, the neighborhood in which it resides, the influence of the EA, and the broader community and city influences where she lives and teaches.

Similar to the schools in Reggio Emilia, Italy - born out of the aftermath of war with the expressed political vision of offering children more than the status quo Keystone is "creating [its] own narrative" and proving that "other worlds are possible, where other stories cannot only be told but enacted, and not only enacted but sustained" (Moss, 2019, p. 18). As I stated in Chapter 1, stereotypes are often applied to Keystone, 
demonstrated through school visit cancellations and questions about neighborhood safety. Yet when visitors "risk" a school tour they are rewarded with a counternarrative of children as competent and capable. Shauntá, the teachers and administrators at Keystone, and all of the coaches and schools involved in the Excellence Academy are demonstrating that all children deserve and can benefit from approaches to learning like Reggio, when their teachers and school communities have access to the resources necessary to dig into the approach. Teachers like Shauntá make clear that all children are competent, capable, brilliant, and rich with possibilities.

\section{Reconceptualizing Children - And Teachers}

The reconceptualist movement and the Reggio approach are two parallel developments in early education that share philosophical, theoretical, and pedagogical principles and practices. As my analysis came to a close, it became clear to me that Shauntá was enacting a reconceptualist stance without even realizing it. For example, as she enacted a pedagogy of time, she prioritized children's agendas and afforded them uninterrupted periods of time for play and exploration that lasted for months in the airport study. As Shauntá enacted a pedagogy of inviting, she centered children's voices and invited connections their lived experiences, such as when children shared stories of going to the doctor and she developed curriculum in response. As she validated children's learning through a pedagogy of documenting, she confirmed to the children and the broader community that she recognized their ideas as important, valuable, and worthy of further discussion, opening up spaces for a more democratic classroom (e.g., PaciniKetchaw et al., 2015). Each of these pedagogies demonstrated reconceptualist ideas and refused commonly held assumptions about children, childhood, and early education. In 
these ways, taking up the Reggio philosophy through her pedagogical stances positioned Shauntá as an agent for change in disrupting the dominant narratives of early childhood education. Shauntá's enactment of the pedagogies of time, inviting, and documenting created spaces for a more democratic realization of curriculum and classroom life, in which all perspectives were valued and all voices were heard.

The reconceptualist movement is adding diverse voices to the narratives of early childhood education (Moss, 2019). The movement calls for new ways to think about children and childhood, honoring the perspectives of children who have traditionally been silenced. I argue that in order to reconceptualize children, we must first reconceptualize teachers. Teachers, of course, are the ones doing the work of early education daily, in explicit and subtle ways. In order for there to be any measure of change in a movement that prioritizes and legitimizes the lived experiences of children and their families, it is imperative that teachers are recognized as the catalysts for potential. As Shauntá frequently emphasized, taking up the Reggio approach was an important and ongoing journey, one that helped and continues to help her see children in new ways.

Teaching in the "Reggio way" is a revolutionary move on Shauntá's part. Although she teaches in a space where the larger conversations focus almost exclusively on "quality" and "readiness," she finds ways to enact pedagogy that honors children and teachers and doesn't adhere to the early childhood narratives so common in her community and beyond. Her teaching is a political move, one that resists the notion that children and childhood are universal experiences, independent of social, political, and economic contexts. 


\section{An Unexpected Outcome}

In this feminist ethnographic study, I learned that the pedagogies Shauntá enacted support and extend a reconceptualist perspective to early childhood education. The findings of this study confirm the importance of providing counternarratives that disrupt the dominant discourses perpetuated by educators who adhere to a developmental and child-centered approach to early learning. This study contributes an alternative narrative (Moss, 2019) that places those who are traditionally disempowered into an asset perspective and amplifies the need to question the dominant narratives.

One of the most significant outcomes of this research is that it demonstrated the power of co-researching with Shauntá. I attribute this in part to the use of Learning Stories, which brought our co-research to levels we had not experienced previously. Through the conversations generated by writing and sharing Learning Stories, Shauntá and I recognized that we were co-constructing new knowledges together, an important application of the Reggio philosophy. I learned from her about what she was doing pedagogically as she explained her thinking and teaching decisions. She learned from me how to give language to what I saw, as I described the teaching and learning I valued in her classroom. This co-construction was a way for me to acknowledge Shauntá as an expert of her classroom and the pedagogies she enacted there. Learning Stories, therefore, produced validation for the shifts in her practices over time, and created a method that has the potential as a teaching tool, for practicing and preservice educators.

\section{Conclusion}

Reggio educators identify relationships as foundational to their work with children. These relationships are fostered in the interactions between adult and child, 
child and child, and between humans and the environment. Shauntá took up the identity of a Reggio teacher and by extension, enacted pedagogies in her classroom through interactions based in relationships. In the pedagogy of time, she encouraged relationship building by committing unrestrained spans of time for children to engage with one another and their environment. In the pedagogy of inviting, she designed material invitations that encouraged children to be in relationship with objects in their environment. When she invited children to connect to their lived experiences, she encouraged relationships between children based on their shared experiences, such as going to the doctor or shopping at the grocery store. In the pedagogy of documenting, she told the stories of children's learning, often inviting them to co-author those stories alongside her. Pedagogical work in Reggio Emilia is rooted in relationships; through her intentional interactions with children, Shauntá embodied that pedagogical work in her own classroom.

Taking up the Reggio approach positions children and teachers as full of potential. Empowering children through the enactment of pedagogies rooted in interaction and relationships was also powerful for Shauntá. As she always said, becoming Reggio-inspired was a "journey. A good journey.” Part of this journey was advocating for children beyond the walls of her school by documenting and sharing her own journey and her new understandings of children and herself as a teacher by coauthoring papers and delivering presentations with me and other research team members. Empowering children empowered Shauntá: she now teaches in ways that disrupt deficit stereotypes and demonstrate the wealth of knowledges children bring from their lived experiences, whatever those experiences might be. 


\section{Implications for Future Research and Practice}

As is common in qualitative studies, I collected far more data than was reported here. The data collected during my time in Shauntá's classroom is rich with possibilities for future analysis. I intend to revisit the data to pursue the following threads for research and practice.

\section{Research}

Consistent with feminist poststructural and reconceptualist lenses, I intend to return to the data collected during this study with a gender-focused lens. Often during my observations, I noted interesting moments when children performed gender in both stereotypical and non-stereotypical ways. I will also return to the fieldnotes, photographs, and video recordings and look specifically at moments when Shauntá played with children. Building on the work of Whitmore (2015), I will pay particular attention to how language was used, and the content of the conversations when teacher and children engaged in pretend or other play when teachers play alongside children.

The relationship I developed with Shauntá over my years as a guest in her classroom is another area for further inquiry, particularly in terms of how our language represented our relationship as it changed over time. For example, I want to look at the shifts in Shauntá's and my speech from our earliest interactions to those near the conclusion of the study. Oftentimes, Shauntá or I would say to the other, "Remind me to tell you about..." This indicated a level of comfort, familiarity, and trust that was built over time and was not typical of all researcher-"participant" relationships. Revisiting the data with this lens will also be an opportunity to analyze our conversations as related to 
when and how we interrupted and revisited certain topics: What was important enough to return to? What did it indicate when Shauntá or I said, "We can't forget to talk about...”?

Finally, I am compelled to think more deeply about Learning Stories as a feminist data elicitation method. Developing methods that encourage more equity of power in researcher-participant relationships is worth deep consideration. Theorizing Learning Stories and adapting them for use with adults will be one way to see deeper understanding and potential realized.

\section{Practice}

Each of the pedagogies of time, inviting, and documenting (as well as the ways the pedagogies intertwine and affect one another) offers classroom teachers suggestions for Reggio-inspired and reconceptualist practices. A pedagogy of time offers the potential of deeper learning through prolonged engagement. A pedagogy of inviting offers the potential of acknowledging and building upon the myriad knowledges children bring into the classroom. A pedagogy of documenting offers the potential for seeing children as whole and telling the stories of their learning. The counternarratives from Shauntá's classroom have the potential to demonstrate what is possible in classroom practices when teachers embrace a reconceptualist perspective. There is also the potential for demonstrating to teacher educators how these Reggio-inspired and reconceptualist practices can be privileged over readiness, inauthentic assessment measures, and other narratives to more fully demonstrate the competencies and capabilities of all children.

Further, this study suggests strong possibilities for the use of Learning Stories as a coaching tool in professional development programs like the Excellence Academy. Adapting Learning Stories, more typically written by teachers for children and their 
families, for use with teachers was a generative means for me to connect with Shauntá and holds promise for intentional discussions with other teachers about their practice. There is much potential for coaches and directors to use Learning Stories to foster more symmetrical interactions with teachers and approaching conversations about practice from the perspective of recognition and celebration, rather than evaluation.

\section{Final Thoughts}

Reggio founder Loris Malaguzzi (2012) conceptualized children as having “a hundred languages (and a hundred hundred hundred more)" (p. 3). This conceptualization was the foundational ideology as he and his colleagues developed in their now-famous approach to early education. I believe this idea also applies to teachers, particularly those who work tirelessly to amplify those languages for children. I end here with an adaptation of Malaguzzi's poem entitled No Way. The Hundred is There, adapted for all teachers doing the vital work of educating young children, and in particular, for Shauntá.

The teacher

is made of one hundred.

The teacher has

a hundred languages

a hundred hands

a hundred thoughts

a hundred ways of thinking

of playing, of speaking.

A hundred always a hundred

ways of listening

of marveling, of loving

a hundred joys... 


\section{REFERENCES}

Ahmed, S. (2017). Living a feminist life. Durham, NC: Duke University Press.

Angleton, C. \& Whitmore, K.F. (in press). Validating manifestations with learning stories. In R.J. Meyer and K.F. Whitmore (Eds.). Reclaiming literacies as meaning making. New York, NY: Routledge.

Announcing Kentucky All STARS (n.d.) Retrieved from https://education.ky.gov/curriculum/conpro/prim-pre/Pages/default.aspx.

Blaiklock, K. (2013). What are children learning in early childhood education in New Zealand? Australasian Journal of Early Childhood, 38(2), 51-56.

Blaise, M. (2005). Playing it straight: Uncovering gender discourses in the early childhood classroom. New York, NY: Routledge.

Bloch, M.N., Swadener, B.B., \& Cannella, G.S. (2014). Exploring reconceptualist histories and possibilities. In M.N. Bloch, B.B. Swadener, and G.S. Cannella (Eds.). Reconceptualizing early childhood care and education: Critical questions, new imaginaries, and social activism (1-16). New York, NY: Peter Lang.

Cadwell, L. B. (2003). Bringing learning to life: The Reggio Approach to early childhood education. New York, NY: Teachers College Press.

Cadwell, L.B. (1997). Bringing Reggio Emilia home: An innovative approach to early Childhood education. New York, NY: Teachers College Press.

Cagliari, P., Filippini, T., Giacopini, E., Bonilauri, S., \& Margini, D. (2012). The 
pedagogical coordinating team and professional development. In C. Edwards, L. Gandini, and G. Forman (Eds.). The hundred languages of children: The Reggio Emilia experience in transformation (3rd ed.) (135-146). Santa Barbara, CA:

Praeger.

Cannella, G.S. (1997). Deconstructing early childhood education: Social justice and revolution. New York, NY: Peter Lang.

Carr, M. \& Lee, W. (2012). Learning Stories: Constructing learner identities in early education. Los Angeles, CA: Sage.

Carter, M. (2010). Using “Learning Stories” to strengthen teachers' relationships with children. Exchange, 40-44.

Charmaz, K. (2014). Constructing grounded theory (2nd ed.). Los Angeles, CA: Sage.

Clark, A. (2010). Young children as protagonists and the role of participatory, visual methods in engaging multiple perspectives. American Journal of Community Psychology, 46, 115-123.

Copple, C. \& Bredekamp, S. (Eds.). (2009). Developmentally appropriate practice in early childhood programs serving children from birth through age 8 (3rd ed.). Washington, DC: NAEYC.

Curtis, D. \& Carter, M. (2015). Designs for living and learning: Transforming early childhood environments (2nd ed.). St. Paul, MN: Redleaf Press.

Curtis, D. \& Carter, M. (2013). The art of awareness: How observation can transform your teaching (2nd ed.). St. Paul, MN: Redleaf Press.

Dahlberg, G. (2012). Pedagogical documentation: A practice for negotiation and democracy. In C. Edwards, L. Gandini, and G. Forman (Eds). The hundred 
languages of children: The Reggio Emilia experience in transformation (3rd ed.) (225-231). Santa Barbara, CA: Praeger.

Dahlberg, G., Moss, P., \& Pence, A. (2013). Beyond quality in early childhood education and care: Languages of evaluation. New York, NY: Routledge.

Davies, B. (2014). Listening to children: Being and becoming. New York, NY: Routledge.

Davies, B. (2003). Frogs and snails and feminist tales: Preschool children and gender. Cresskill, NJ: Hampton Press, Inc.

Edwards, C., Gandini, L., \& Forman, G. (Eds.). (2012). The hundred languages of children: The Reggio Emilia experience in transformation. Santa Barbara, CA: Praeger.

Farquhar, S. (2016). Time in early childhood: Creative possibilities with different conceptions of time. Contemporary Issues in Early Childhood, 17(4), 409-420.

Forman, G. \& Fyfe, B. (2012). Negotiated learning through design, documentation, and discourse. In C. Edwards, L. Gandini, and G. Forman (Eds.). The hundred languages of children: The Reggio Emilia experience in transformation (3rd ed.) (247-271). Santa Barbara, CA: Praeger.

Fraser, S. \& Gestwicki, C. (2002). Authentic childhood: Exploring Reggio Emilia in the classroom. Albany, NY: Delmar.

Gandini, L. (2012a). History, ideas, and basic principles: An interview with Loris Malaguzzi. In C. Edwards, L. Gandini, and G. Forman (Eds.). The hundred languages of children: The Reggio Emilia experience in transformation (3rd ed.) (27-71). Santa Barbara, CA: Praeger. 
Gandini. L. (2012b). Connecting through caring and learning spaces. In C. Edwards, L. Gandini, and G. Forman (Eds.). The hundred languages of children: The Reggio Emilia experience in transformation (3rd ed.) (317-341). Santa Barbara, CA: Praeger.

Glesne, C. (2015). Becoming qualitative researchers: An introduction (5th ed.). New York, NY: Pearson.

Green, L. (2002). African American English: A linguistic introduction. Cambridge, England: Cambridge University Press.

Hanrahan, V., Niles, A., \& Whtye, M. (2019). Learning Stories: One of New Zealand's unique contributions to early childhood education. Exchange, 12-15.

Harding, S. (1987). Is there a feminist method? In S. Harding (Ed.). Feminism and methodology: Social science issues (1-14). Bloomington, IN: Indiana University Press.

Heydon, R., Crocker, W., \& Zhang, Z. (2014). Novels, nests and other provocations: Emergent literacy curriculum production in a childcare centre. Journal of Curriculum Studies, 46(1), 1-32.

hooks, b. (2010). Teaching critical thinking: Practical wisdom. New York, NY: Routledge.

Kashin, D.L. (2007). Reaching the top of the mountain: The impact of emergent curriculum on the practice and self-image of early childhood educators (Unpublished doctoral dissertation). University of Toronto, Toronto, ON.

Kirsch, G.E. (2005). Friendship, friendliness, and feminist fieldwork. Signs, 30(4), 2163-2172. 
Kline, L.S. (2008). Documentation panel: The "making learning visible" project. Journal of Early Childhood Teacher Education, 29(1), 70-80.

Labov, W. (1973). Language in the inner city: Studies in the Black English Vernacular. Philadelphia, PA: University of Pennsylvania Press.

Langford, R. (2010). Critiquing child-centred pedagogy to bring children and early childhood educators into the centre of a democratic pedagogy. Contemporary Issues in Early Childhood, 11(1), 113-127.

Lewin-Benham, A. (2006). Possible schools: The Reggio approach to urban education. New York, NY: Teachers College Press.

López, F.A. (2017). Altering the trajectory of self-fulfilling prophecy: Asset-based pedagogy and classroom dynamics. Journal of Teacher Education, 68(2), 193 212.

Malaguzzi, L. (2016). The final years 1990-93. In P. Cagliari, M. Castagnetti, C. Giudici, C. Rinaldi, V. Vecchi, and P. Moss (Eds.). Loris Malaguzzi and the schools of Reggio Emilia: A selection of his writings and speeches, 1945-1993 (361-426). New York, NY: Routledge.

Merriam, S.B. \& Tisdell, E.J. (2016). Qualitative research: A guide to design and implementation (4th ed.). San Francisco, CA: Jossey-Bass.

Meyer, R.J. \& Whitmore, K.F. (Eds.). (in press). Reclaiming manifestations of literacies: Cultivating a discourse of meaning making. In R.J. Meyer and K.F. Whitmore (Eds.). Reclaiming Literacies as Meaning Making. New York, NY: Routledge.

Millan, J. (2012). Birth on the playground: Boys' experiences playing with gender. Indo Pacific Journal of Phenomenology, 12(1), 1-11. 
Morris, K.L. (2017). Informed asset-based pedagogy: Coming correct, counter-stories from an information literacy classroom. Library Trends, 66(2), 176-218.

Moss, P. (2019). Alternative narratives in early childhood, or why contest early childhood?. Innovations in Early Education: The International Reggio Emilia Exchange, 26(1), 12-21.

Pacini-Ketchabaw, V. (2012). Acting with the clock: Clocking practices in early childhood. Contemporary Issues in Early Childhood, 13(2), 154-160.

Pacini-Ketchabaw, V., Nxumalo, F., Kocher, L., Elliot, E., \& Sanchez, A. (2015). Journeys: Reconceptualizing early childhood practices through pedagogical narration. Toronto, ON: University of Toronto Press.

Paley, V.G. (2005). A child's work: The importance of fantasy play. Chicago, IL: University of Chicago Press.

Paananen, M. \& Lipponen, L. (2018). Pedagogical documentation as a lens for examining quality in early childhood education. Early Child Development and Care, 188(2), 77-87.

RECE International (2014). Reconceptualizing early childhood elementary: A brief introduction. Retrieved from http://www.receinternational.org/about.html\#sthash.dJ3CJ6qi.dpbs.

Rinaldi, C. (2006). In dialogue with Reggio Emilia: Listening, researching, and learning. New York, NY: Routledge.

Ryan, S. (2005). Freedom to choose: Examining children's experiences in choice time. In N. Yelland (Ed.). Critical Issues in Early Childhood Education (99-114). Berkshire, England:Open University Press. 
Saldaña, J. (2015). Thinking qualitatively: Methods of mind. Los Angeles, CA: Sage.

Scheinfeld, D.R., Haigh, K.M., \& Scheinfeld, S.J.P. (2008). We are all explorers: Learning and teaching with Reggio principles in urban settings. New York, NY: Teachers College Press.

Scheurich, J.J. \& Young, M.D. (1997). Coloring epistemologies: Are our research epistemologies racially biased? Educational Researcher, 26(4), 4-16.

Souto-Manning, M. (2014). Critical narrative analysis: The interplay of critical discourse and narrative analyses. International Journal of Qualitative Studies in Education, 27(2), 159-180.

Stacey, S. (2018). Emergent curriculum in early childhood settings: From theory to practice. (2nd ed.). St. Paul, MN: Redleaf Press.

Stephen, C. (2010). Pedagogy: The silent partner in early years learning. Early Years, $30(1), 15-28$.

Sunstein, B.S. \& Chiseri-Strater, E. (2012). FieldWorking: Reading and writing research (4th ed.). Boston, MA: Bedford/St. Martin's.

Tobin, J., Hsueh, Y., \& Karasawa, M. (2009). Preschool in three cultures revisited: China, Japan, and the United States. Chicago, IL: The University of Chicago Press.

Wein, C.A. \& Kirby-Smith, S. (1998). Untiming the curriculum: A case study of removing clocks from the program. Young Children, 53(5), 8-13.

Whitmore, K.F. (2018). Documenting stories on the journey toward excellence: A mid term evaluation study of the Excellence Academy. Provided to Metro United Way. 


\section{APPENDIX A: FIELD NOTE PROTOCOL}

Data overview:

Date:

Time:

Brief context:

Abstract of observation:

Detailed fieldnotes:

Analysis of focus elements:

1. Emergent curriculum

2. Environment as third teacher

3. Documentation

4. Anything else of note

5. Discussion and reflection (interpretations, comments, questions, connections, concerns, impressions)

6. Subjectivity questions from Sunstein and Chiseri-Strater, 2012:

a. What surprised me?

b. What intrigued me?

c. What disturbed me?

7. Points of tension

8. How did I affect the data today? How did my presence influence the adults, the kids, the space? 


\section{APPENDIX B: EXCELLENCE ACADEMY INTERVIEW PROTOCOL}

INTERVIEW ONE (teaching history and EA background narrative)

1. When we met with the other teachers at your center, you drew your teaching history. Would you please walk me through what your drawing shows about you as a teacher?

2. What is one particularly memorable story from your time as a teacher?

3. What experiences to date have you had in the Excellence Academy? (follow up)

4. How are you currently keeping track of the children's development and learning in your classroom/center? (documentation, learning stories, TSG, etc.)

INTERVIEW TWO (classroom environment narrative)

1. Thinking about your classroom specifically, what are the spaces you like the most and why? Which spaces are most important to you and why? (Would you show me the space and explain how it operates?)

2. What elements do you consider essential in an early childhood classroom environment?

3. If cost and space were no obstacle, describe your ideal classroom.

4. How are you currently keeping track of the children's learning and development in your classroom/center? (documentation, learning stories, TSG, etc.)

INTERVIEW THREE (retrospective narrative)

1. For this conversation, I'd like to talk with you as you look back and reflect on this past year in the Excellence Academy. Could you share some stories of valuable experiences from your time in the EA? (follow up)

2. What are some highlights (positive or negative) from the past year in the program? 3. As you think back over the past year, is there one particular story that is especially meaningful to you?

4. How are you currently keeping track of the children's learning and development in your classroom/center? (documentation, learning stories, TSG, etc.)

5 . What is next for you as a teacher? 


\title{
CURRICULUM VITAE
}

\section{Christina Angleton}

christina.angleton@1ouisville.edu | 816.813.8630

\section{Education}

$\begin{array}{lll}\text { PhD } 2019 & \begin{array}{l}\text { Curriculum and Instruction } \\ \text { Early Childhood and Elementary Education } \\ \text { University of Louisville }\end{array} \\ \text { BS } 2006 & \begin{array}{l}\text { Early Childhood Education } \\ \text { Southern Illinois University }\end{array}\end{array}$

\section{Academic and Professional Experiences}

\author{
Date \\ $08 / 2019$ \\ Position/Employer \\ Assistant Professor \\ College of Education \\ Illinois State University, Normal, IL \\ 07/2016 - 06/2019 Graduate Research Assistant \\ Early Childhood Research Center \\ University of Louisville, Louisville, KY \\ 01/2016 - 05/2019 Adjunct Instructor, Children's Literature \\ College of Education and Human Development \\ University of Louisville, Louisville, KY \\ 08/2013 - 07/2016 Preschool Facilitator \\ Practicum Supervisor \\ University of Louisville Early Learning Campus \\ Louisville, KY \\ 08/2011 - 08/2013 Lead Toddler Teacher \\ Practicum Supervisor \\ Hiersteiner Child Development Center \\ Overland Park, KS \\ $11 / 2009-11 / 2010$ \\ Early Preschool Teacher \\ Creative World \\ Lee's Summit, MO
}




$\begin{array}{ll}07 / 2009-1 / 2008 & \text { Kindergarten Teacher } \\ & \text { The Goddard School } \\ & \text { Overland Park, KS }\end{array}$

6/2006 - 8/2007 Lead Toddler Teacher/Graduate Assistant Practicum Supervisor Child Development Laboratories Southern Illinois University, Carbondale, IL

8/2003 - 5/2006 Assistant Teacher Child Development Laboratories Southern Illinois University, Carbondale, IL

\section{Research}

Dissertation Study: Reconceptualizing the Teacher's Role in Emergent Curriculum in a Reggio- Inspired Urban Preschool Classroom

Ethnographic, qualitative study of an urban preschool classroom with an emphasis on learning environment, emergent curriculum, and pedagogical documentation

Graduate Research Assistant (3 years): Documenting Stories on the Journey Toward Excellence: An Evaluation Study of the Excellence Academy (Dr. Kathryn F. Whitmore, $\mathrm{PI})$

- Data collection and management: participant observations, interviews, cofacilitation of action research events and teacher workshops, classroom mapping and analysis

- Qualitative analysis using NVivo software

- Contributions to Year 1 and Year 2 reports to the funding agency

- Dissemination at local, regional, and national conferences

- Manuscripts in preparation for Talking Points, Language Arts, Innovations: North American Reggio Emilia Alliance, Journal of Early Childhood Literacy, others

Additional research experience:

Promising Practices in Early Head Start: Children, Teachers, and Families (Dr. Kathryn F. Whitmore, PI)

- Data collection and management, including observations and interviews and management of paper and digital data

- Data analysis using NVivo

- Dissemination in regional conference

Black Men as Agents of Social Change in Children's Literacy Success: A Study of the Effects of Volunteer Readers and Early Literacy Behaviors in a Pediatric Clinic Waiting Room (Dr. Kathryn F. Whitmore, PI) 
- Member of transdisciplinary research team

- Assist with qualitative study design

- Data collection and management

Beginning Literature Study (Dr. Kathryn F. Whitmore, PI)

- Graduate research assistant on a teacher research study in a third grade classroom

- Data collection and management, including participant observations, interviews, and management of paper and digital data

- Manuscripts in preparation for Language Arts, Talking Points, and The Reading Teacher

\section{Courses Taught}

Instructor of Record, Children's Literature

- Undergraduate course focused on reading and responding to high quality, diverse literature for children, PreK-8th grade

- Created and facilitated in-class engagements with strategies for reading and responding to literature with children in and out of classroom spaces; provide written weekly feedback on students' writing and multimodal projects; advise students in the creation of a text set of children's literature for inquiry study

Teaching Assistant, Teaching Adolescent Readers

- Assisted professor of record for undergraduate course for reading young adult literature and creating a young adult literature pedagogy

- Provided weekly feedback to students' written and multimodal responses to literature; develop in class engagements for responding to young adult literature; facilitated whole-class and small group discussions

\section{Publications}

Whitmore, K.F., Angleton, C., Pruitt, J., \& Miller, S. Putting a focus on children as competent and capable with the Visual Learning Analysis (VLA). In preparation for submission to Early Childhood Education Journal.

Miller, S., Pruitt, J., Angleton, C., \& Whitmore, K.F. (in press for 11/2019). Zooming in on the details: Visual Learning Analysis. Talking Points.

Angleton, C. \& Whitmore, K.F. (in press). "Where are we going today?": Emergent Curriculum in a Reggio-Inspired Preschool Classroom. In R.J. Meyer and K.F. Whitmore (Eds.). Reclaiming Literacies as Meaning Making.

Angleton, C. \& Whitmore, K.F. (in press). Validating Manifestations with Learning Stories. In R.J. Meyer and K.F. Whitmore (Eds.). Reclaiming Literacies as Meaning Making. 
Whitmore, K.F. \& Angleton, C. (2017). Take that Ronald!: Disrupting gender binaries in preschool. In R.J. Meyer and K.F. Whitmore (Eds.). Reclaiming Early Childhood Literacies: Narratives of Hope, Power, and Vision. (49-59). New York, NY: Taylor \& Francis.

Whitmore, K.F., Angleton, C., \& Zuccaro, E.L. (2016) Picturebooks and Gender: Making Informed Choices for Equitable Early Childhood Classrooms. Mid-South Literacy Journal, 2(1), 14-20.

\section{Publications (in preparation)}

Angleton, C. Content analysis as a legitimate method for interrogating issues of power in children's literature. In preparation for submission to Journal of Children's Literature.

Angleton, C. Windows, mirrors, and megaphones: African American English in picturebooks. In preparation for submission to Mid-South Literacy Journal.

Warren, K., Whitmore, K.F., \& Angleton, C. My kids only know Dr. Seuss!: Literature study to grow 3rd graders' reading identities around African American authors of children's literature. In preparation for submission to Talking Points or The Reading Teacher.

Whitmore, K.F., Warren, K., \& Angleton, C. The "Good," the "Bad," and the Illegal": 3rd-grade thinking about race and author/illustrator choices. In preparation for submission to Language Arts.

\section{Presentations}

\section{National:}

Angleton, C. (2019). Using Critical Content Analysis to Interrogate Issues of Power in Children's Literature. Georgia Conference on Children's Literature, Athens, GA.

Angleton, C., Miller, S., Branstetter, L., \& Pruitt, J. (2018). Understanding the Preschool Environment as the "Third Teacher" from a Reggio Perspective. National Association for the Education of Young Children Professional Learning Institute, Austin, TX.

Whitmore, K.F. \& Angleton, C. (2018). Young Children at Play: Noticing Their Language and Literacy Growth. Literacies for All Summer Institute, Baltimore, MD.

Zuccaro, E.L. \& Angleton, C. (2018). Reflective Tools for Choosing High Quality Picturebooks in Equitable Classrooms. National Conference of Teachers of English, Houston, TX. 
Zuccaro, E.L., Angleton, C., Langston-Demott, B. (2017). Critical Literacy and Gender: Reflective Tools for Choosing High Quality Picturebooks. National Conference of Teachers of English, St. Louis, MO.

Whitmore, K.F., Warren, K., Angleton, C. (2017) The "Good," the "Bad," and the "Illegal": $3^{\text {rd }}$ Grade Thinking about Race and Author/Illustrator Choices. National Conference of Teachers of English, St. Louis, MO.

Zuccaro, E.L., Angleton, C., Laman, T.T., Whitmore, K.F., Henderson, J. \& Warren, K. (2016). Reclaiming curiosity: Having the courage to inquire with kids. Literacies for All Summer Institute, St. Louis, MO.

Whitmore, K.F., Angleton, C., \& Herbert, K. (2015). Take That, Prince Ronald!: Powerful Picturebooks that Help Four- and Five-Year-Olds Disrupt Gender Binaries. Whole Language Umbrella Literacies for All Summer Institute, Atlanta, GA.

\section{Local/Regional:}

Angleton, C. (2019). Learning Stories: Reconceptualizing Teacher Identity Through Reflective Narratives. University of Kentucky Spring Research Conference, Lexington, KY.

Whitmore, K.F., Angleton, C., Miller, S., Branstetter, L., \& Pruitt, J. (2018).

Environment as Third Teacher: A Reggio Approach to Preschool Classrooms. Southern Early Childhood Association Annual Conference, Lexington, KY.

Whitmore, K.F., Zuccaro, E.L., Angleton, C., \& Wheeler, E. (2018). “I Just Didn't Know": Stories and Reflections about Becoming Champions. Southern Early Childhood Association Annual Conference, Lexington, KY.

Angleton, C. (2018). Windows, Mirrors, and Megaphones: African American English in Picturebooks. University of Louisville Spring Research Conference, Louisville, KY.

Branstetter, L., Pruitt, J., Miller, S., \& Angleton, C. (2018). Environment as Third Teacher: A Reggio Approach to Preschool Classroom Spaces. Early Childhood Institute, Louisville, KY.

Warren, K., Whitmore, K.F., Angleton, C. (2017). The "Good," the "Bad," and the "Illegal": $3^{\text {rd }}$ Grade Thinking about Race and Author/Illustrator Choices. Kentucky Reading Association Conference, Louisville, KY.

Burns, H., Whitmore, K.F., Angleton, C. (2014) Taking Advantage of the Power of Play, Language, and Pretend in the World of Jack and the Beanstalk. Ready Kids Conference, Louisville, KY. 
Angleton, C. (2013). Art with infants and toddlers: Embrace the mess! Mid-America Association of Education of Young Children Annual Conference, Overland Park, KS.

\section{Service}

NCTE Annual Conference Proposal Review Committee, 2019-2020

- Review and evaluate proposals for the National Council of Teachers of English Annual Conference

Graduate Student Council Department Representative, 2018-2019

- Research Grant Review Committee: Review and evaluate graduate student research grant proposals, and award grants to chosen recipients

Bernheim Forest's Children @ Play Initiative, 2015-2016

- Member of initiative coordinated by Bernheim Arboretum and Research Forest promoting outdoor play in and around Louisville, KY in the form of pop-up playground events and trainings for teachers and other community members about the importance of unstructured play in children's lives

\section{Professional Memberships}

National Association for the Education of Young Children (NAEYC)

Southern Early Childhood Association (SECA)

National Council for Teachers of English (NCTE)

Whole Language Umbrella of NCTE

Children's Literature Assembly of NCTE

Early Childhood Education Assembly of NCTE

\section{Honors and Awards}

Faculty Favorite Award Nomination, 2017-2018 School Year

Whole Language Umbrella Scholarship, 2016 Literacies for All Summer Institute

\section{Related Skills}

Multimodal/Technology: Prezi, Infographics

Experience with NVivo data analysis software 